\title{
Ageing Economics: Human Capital, Productivity and Fertility
}

\section{Creina Day and Steve Dowrick}

\begin{abstract}
A long with many other advanced economies, Australia faces an ageing population as a result of declining fertility over the last few decades and increasing longevity. The OECD (2003:1) is sounding the alarm on the economic effects of ageing, predicting falling living standards unless remedial policy action is taken.
\end{abstract}

If nothing is done quickly to extend working lives, living standards will fall in the course of the coming decades. We know, because of the ageing of our population, that there will be fewer and fewer persons of working age to support more and more older people. For the OECD as a whole, the dependence ratio of older people (i.e. those aged 65 and over as a proportion of those aged 20-64) will rise from the current figure of 22 per cent to 46 per cent in 2050.

Given current policy commitments to government funding of pensions and health and aged-care, the ageing of the population over the next fifty years is predicted to increase demands on the public purses of OECD countries by, on average, between six and seven percent of GDP (OECD, 2001b).

The demographic changes facing Australia are likely to be slightly less severe than the OECD average. This is partly because the fertility rate amongst Australian women has not fallen as low as it has in many European countries, and also because Australia runs a relatively large immigration program. Projections in the inaugural Intergenerational Report (Commonwealth of Australia, 2002) suggest that the most likely outcome is a doubling in the aged dependency ratio (defined as the population aged over 64 relative to the population aged 15-64) from 19 per cent to 40 per cent over the next forty years. Age-sensitive demands on the public purse are projected to rise by five percent of GDP over the same period, with the rising needs of the elderly offset slightly by reduced spending on education as the proportion of young people in the population diminishes. These projections are summarised in Table 1.

Intergenerational equity is one of the primary concerns of those who are alarmed at the implications of these demographic changes. They are concerned that the living standards of future generations will be adversely and unfairly affected by the increase in the dependency ratio and the potential increase in the tax burden.

Creina Day is a doctoral student in economics and Steve Dowrick is Professor of Economics and ARC Senior Fellow, both in the School of Economics at the Australian National University 
Table 1: Demographic and Fiscal Projections

\begin{tabular}{lcc}
\hline \multicolumn{2}{c}{ Ratio of 'Dependents' to Population Aged 15-64 (per cent) } & $\mathbf{2 0 4 2}$ \\
Population 65+ & 19 & 40 \\
Population 0-14 & 29 & 24 \\
Population 0-14 and 65+ & 48 & 64 \\
\multicolumn{2}{c}{ Ratio of Commonwealth 'Demographic Spending' to GDP (per cent) } \\
Elderly: health, care and pensions & 7.6 & 14.5 \\
Families, unemployment, children and education & 4.8 & 3.5 \\
Total & 14.0 & 19.0 \\
\hline
\end{tabular}

Source: Commonwealth of Australia (2002):Tables 3 and 13.

In response to these concerns a raft of policy proposals have been canvassed. OECD (2003) calls for policies aimed at increasing the labour force participation by people aged between 55 and 64, trying to reverse the trend of early retirement. They advocate reductions in access to long-term sickness and disability pensions and unemployment benefits, as well as re-training schemes for older workers and reductions in discrimination on the basis of age. Finally, they call for a major change in community attitudes (OECD, 2003:1):

... workers must also understand that early retirement is not a vested right and that they must get used to the idea of a longer career, perhaps taking on different jobs towards the end of their working lives.

While this forced-labour rhetoric is not likely to go down too well in Australia, it illustrates the pressures on public policy that are being generated in the debate over the ageing of the population. Other responses that have been canvassed locally include policies to increase fertility - see McDonald (2001) — as well as policies to further stimulate private superannuation and private medical insurance and to contain the costs of health care for the elderly. Some of these policy changes may well be desirable in their own right. However, the purpose of this paper is not to debate the optimal policy response to population ageing. Rather, it argues that the problematic nature of this current demographic transition has been overstated and that policy debate should not be rushed into hasty and drastic conclusions by undue pessimism. In particular we suggest that the ageingpessimists are failing to consider a number of important countervailing factors:

- The decline in fertility over the past few decades is linked to a concurrent strong rise in labour force participation of Australian women as well as a subsequent rise in average educational attainment.

- This increase in educational capital is likely to sustain strong productivity growth into the future. 
- Despite the projected increase in dependency, with continuing productivity growth real incomes in forty years time will be such that living standards will be much higher than they are today.

- Given that much of the increase in the living standards of the next generation is driven by the investments of the current generation in both physical and human capital, projected increases in the tax burden do not appear to be inequitable. Rather than being a burden on the next generation, the current generation is probably a benefactor.

Part of our argument is similar to that of Guest and McDonald (2001). They assume that multi-factor productivity will grow at one percent per year. Allowing for optimal savings and investment behaviour, they predict that average living standards will rise strongly despite the ageing of the population. We reinforce this finding, which essentially reflects the power of compound growth. Even a fairly slow rate of growth in productivity will raise real income per worker to such an extent that the predicted demographic changes will make only a dent in the growth of income averaged over the whole population. We go beyond the Guest and McDonald argument by considering the endogeneity of technical progress to investment in education, whereas they treat productivity growth as exogenous. We argue that the human capital created through education is not only a productive input which directly raises productivity, it also plays a crucial role in the development and adoption of new technologies that drive long-run growth.

Furthermore, we examine theory and evidence concerning labour force participation and fertility, which suggest that rising levels of education play an important role in decisions on family size. We conclude that rising educational attainment, the factor that has driven the fall in fertility, is also acting to mitigate the effects of rising dependency rates by raising the growth rate of productivity.

\section{Fertility, Human Capital and Labour Force Participation}

As living standards rise, families tend to have less children and the population growth rate falls. This is evident in the historical development of many countries that have progressed beyond the Malthusian poverty trap. This section reviews the literature exploring the interdependency of fertility and economic growth.

While it is true that people tend to live longer as living standards rise, there is little theoretical analysis endogenising longevity. On the other hand, work on endogenous fertility has proliferated. This literature applies rational choice analysis to parental choice over fertility, savings, and investment in the education of children. To some people it is offensive to treat fertility as an economic choice variable. Of course there will always be cultural and religious factors and idiosyncratic variations that affect fertility choices. But these economicdemography models do have substantial explanatory power in relation to the aggregate outcomes that are relevant for macroeconomic analysis.

Various motives are adduced for fertility choice in this literature. Parents may expect to get satisfaction from family life, they may value children 
altruistically, and they may expect to get income support and companionship in old age. On the other hand children come at a cost, with some models distinguishing between the cost of rearing and the cost of education.

The principal theoretical contributions have come from Barro and Becker (1988), Becker, Murphy and Tamura (1990), Ehrlich and Lui (1991), and Galor and Weil (1996 and 2000). In these analyses, increased female labour force participation and accumulation of capital, particularly human capital, are the driving forces that simultaneously raise income levels and reduce fertility. A feature common to most of these models is that economic growth, characterised by rising productivity and wages, has conflicting income and substitution effects on fertility. A rise in income means parents can afford to have more children; but the opportunity cost of rearing children (time out of the labour force) also rises. The latter has tended to dominate in advanced economies and women's participation in the labour force has risen and fertility has declined with economic growth.

Economic growth and fertility are also linked through education and the accumulation of human capital. A rise in levels of human capital investment, such as an increase in educational attainment, has two distinct effects on that generation of young people as they enter adulthood. Not only do they have higher earning potential, but also they are more productive as educators of the next generation. So the return to investment in their children's education rises relative to the return to investment in the quantity of children. This 'quality-quantity tradeoff', a phrase coined by Becker and Lewis (1973), furthers the dynamic interaction between rising productivity and falling fertility. We draw two key predictions from this literature. Declining fertility of the current generation is associated with:

- $\quad$ rising female labor force participation of the current generation; and

- rising education levels of the future generation.

An overall inter-relationship between economic growth and fertility receives empirical support. Barro and Sala-i-Martin (1995) and Barro and Lee (1994) estimate fertility equations using cross-country data over 1965-1985. They find a negative relation between per capita income and fertility holds for all but the poorest countries. Barro and Sala-i-Martin (1995) estimate that fertility declines with economic growth for countries where real per capita GDP is above $\$ 767$ (1985 US dollars). Only 13 of the 102 countries in their regression sample were below this critical level. Using a 1950-1990 time series for four G7 countries, Cigno and Rosati (1996) estimate that fertility is affected positively by the male wage rate and negatively by the female wage rate. Rising male wages have a pure income effect, whereas rising female wages imply both an income effect and a substitution effect, as women primarily face the choice between child rearing and labour force participation. The sum of the wage coefficients is negative, suggesting the substitution effect associated with rising incomes dominates.

Rosenzweig (1990) draws on cross-sectional micro data for three developing countries, as well as time series from India to find evidence of a quality-quantity trade-off as per the second prediction. In all three countries, children's schooling 
responds positively and significantly to variations in parental income across households. Changes in fertility and schooling in Indian farm households, 196171 further supports a quality-quantity trade-off.

In Australia, the first of the predictions accords with the experience of the last four decades. As illustrated in Figure 1, the decline in fertility since the 1960s from an expected three to just under two births per woman - has been accompanied by a substantial rise in the rate of women's participation in the labour force. While much of the rise has taken the form of part-time employment, there has been only a slight decrease in the average hours of work for women. So the participation figures do reflect a large rise in the supply of labour.

\section{Figure 1: Fertility, schooling and female labour force participation}

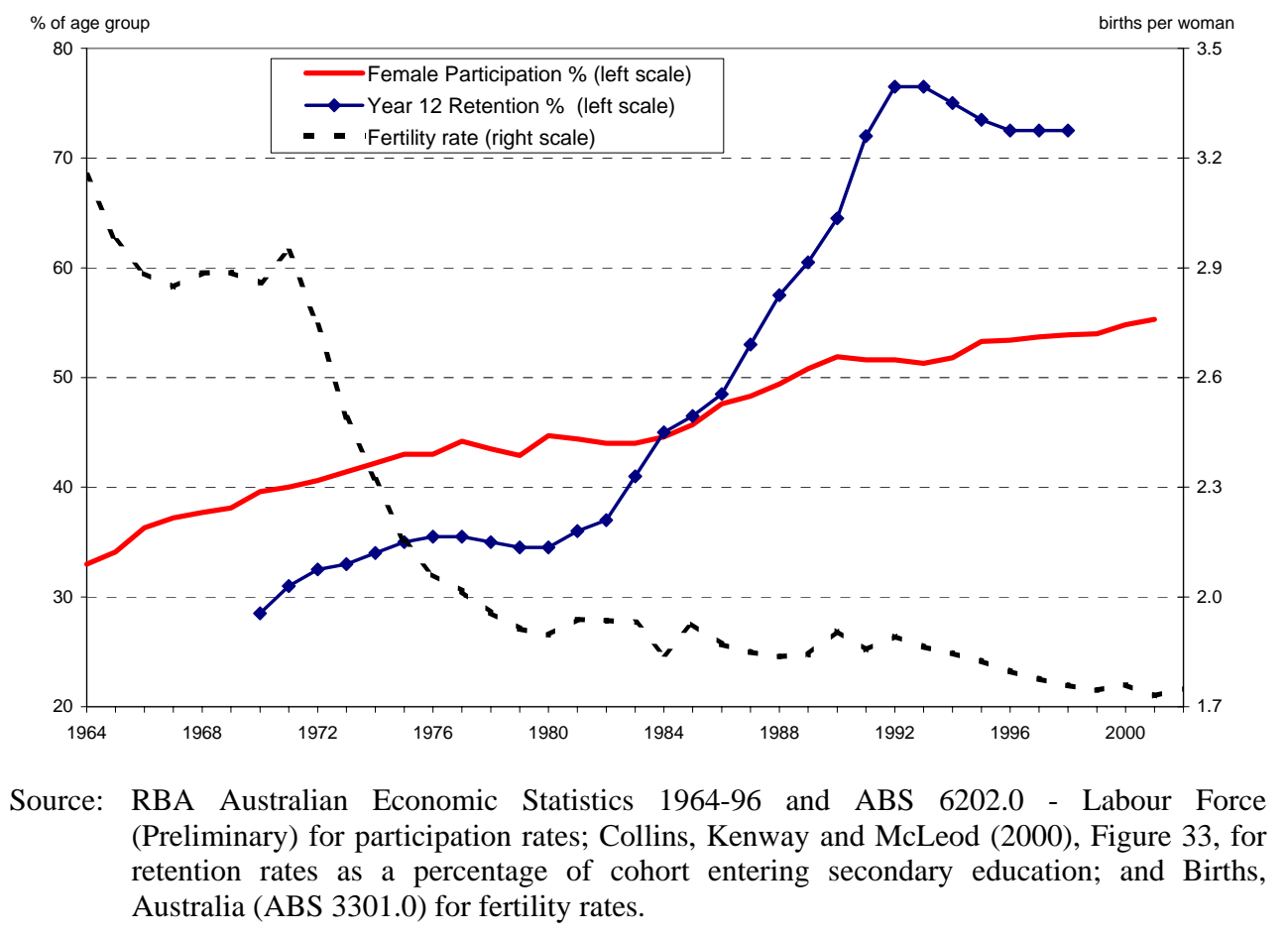

The second prediction of the endogenous fertility literature also accords with Australian experience over the last few decades. Again referring to Figure 1, the sharp fall in fertility beginning in 1970 is reflected in a subsequent take-off in Year 12 retention rates in the mid 1980's. It seems that Australian parents did indeed trade-off between investment in quantity and quality for their children.

\section{Human Capital Investment and Productivity: Level or Growth Effects}

To assess the contribution of rising levels of education to Australian productivity growth, we need to distinguish between 'level effects' and 'growth effects'. The 
former refer to a relationship between the steady-state level of productivity and the rate of accumulation of human capital. The latter refer to a relationship between the stock of human capital and the long-run rate of growth of productivity.

The neo-classical view, championed by Mankiw, Romer and Weil (1992), is that human capital is a productive input subject to diminishing returns. This implies that higher investment will raise the long-run level of labour productivity but will affect the rate of productivity growth only during the transition to the new steady-state. In the long-run, diminishing returns bring the economy back to a steady-state where growth is determined by exogenous technical progress.

Proponents of the 'new' growth theory — Lucas (1988) and Romer (1990) are prominent examples - have advocated the view that investment in embodied human capital (through child-rearing, education and training) and investment in disembodied knowledge (through $R \& D$ ) differs fundamentally from investment in machinery and equipment, and is not necessarily subject to diminishing returns. Policies that affect the stock of human capital have the potential to affect the longrun rate of growth of productivity: growth is endogenous. The essential argument of the new growth theory is that knowledge is non-rivalrous and that its accumulation exhibits positive feedback. For example, the idea of an arch can be used simultaneously in the construction of one bridge or a hundred bridges at no extra cost; and the idea of the arch can inspire further developments in the technology of construction. As the stock of non-rivalrous knowledge grows, so researchers have an ever-broader field on which to make new discoveries.

Human capital can influence the long-run growth of productivity in two ways. The more researchers and the higher their skill levels, the faster the rate at which innovations are generated in research and development. Increasing the skill level of the workforce will also increase the ease and efficiency with which new technologies are introduced into the workplace. Both of these factors have probably been at play in the successful introduction over the past decade of the new computer and Internet technologies in Australian workplaces.

\section{Estimates of the 'Level’ Effects of Investment in Human Capital}

Microeconomic studies in many countries have found that each extra year of schooling raises an individual's earnings by an amount in the range of five to 12 per cent. Findings by Ashenfelter and Krueger (1994) on US data are confirmed by Australian studies such as Miller, Mulvey and Martin (1995), who analyse the earnings of twins and report that the return to a year of education lies between 4.5 per cent and 8.3 per cent, and Preston (1997) who reports high rates of return to advanced educational qualifications. The results of Miller et al. are particularly interesting because they control for the influences of genetic and domestic background to identify the direct contribution of education to subsequent earnings.

These estimates of the returns to education are supported by cross-country macroeconomic studies investigating the link between economic growth and the growth in educational attainment of the workforce in OECD economies. For instance, Mankiw, Romer and Weil (1992) estimate the determinants of countries' 
steady-state income levels as a function of investment in both physical and human capital. For their cross-section of OECD countries, they estimate an elasticity of 0.76 between steady-state output per worker and the rate of investment in education, which they proxy by secondary school enrolment as a proportion of the workforce. Translating the elasticity into the marginal impact of an additional year of schooling, this implies that steady-state output per worker would increase by fifteen percent if average secondary schooling were to increase from five to six years. Bassanini and Scarpetta (2002) analyse annual panel data for 21 OECD countries from 1971 to 1998, concluding that the effect of an additional year of schooling is a six percent increase in steady-state output.

Some researchers argue that the microeconomic correlation between years of schooling and subsequent earnings might be due to the role of education as a signalling device, informing employers of people's natural abilities, rather than education actually adding to people's productivity. However, the fact that macroeconomic growth studies and microeconomic wage studies come up with broadly similar estimates suggests that the wage effect of education does indeed reflect increased productivity.

What are the implications of these estimates for Australia? A rise of one year in the average educational attainment of the workforce is predicted to increase labour productivity and steady-state real GDP by around eight percent, to take a fairly conservative point estimate. This increase in the level of GDP will take place gradually. A one-year increase in the length of schooling of teenagers will only increase the average educational experience of the adult population as the new, better-educated cohorts enter the workforce, replacing older cohorts. The transition lasts four decades, as people enter the labour force aged 16-20 and exit at an age of about 60. During the transition period the annual growth rate of GDP will be 0.2 percentage points above trend, after which time the growth rate will revert to trend with output eight percent higher than it would have been in the absence of the schooling increase.

\section{Estimates of the Growth Effects of Investment in Human Capital}

An increase in the level of human capital will increase the long-run rate of growth of the economy if the stock of human capital influences the rate of development and introduction of new technologies, as argued by Nelson and Phelps (1966). A better educated work force can more readily identify, adapt and implement new ideas - whether the ideas are generated domestically or overseas. This hypothesis receives empirical support from cross-country growth studies.

Benhabib and Spiegel (1994) compare models that treat human capital as a direct input into production with models treating human capital as an intermediate input into the acquisition of skills and/or knowledge. Their cross-country study favours the latter model. This finding is confirmed by Frantzen (2000) and by Dowrick and Rogers (2002). The predicted growth effects of schooling are summarised in Table 2. Averaging these estimates suggests a boost to annual 
economic growth of one half of a percentage point for every additional year of schooling in the adult population.

Table 2: Predicted Growth Effects from an Additional Year of Schooling

\begin{tabular}{|l|c|}
\hline & Increase in long-run rate of growth of productivity \\
\hline \hline Benhabib and Spiegel (1994) & 0.3 percentage points \\
\hline Frantzen (2000) & 0.8 percentage points \\
\hline Dowrick \& Rogers (2002) & 0.3 percentage points \\
\hline $\begin{array}{l}\text { This estimate is from the coefficients in Table } 3 \text { of the paper, using the sample of } 35 \text { relatively } \\
\text { rich economies with better data quality. }\end{array}$
\end{tabular}

This macroeconomic evidence is reinforced by a study of industry-level productivity growth covering 12 industries in 13 OECD countries since 1970 - see Griffith, Redding and Van Reenen (2000). Although Australia is not included in their sample, we can draw on the results reported in their Table 9 for countries like Denmark and Norway. In smallish countries that have a similar level of labour productivity to that of Australia, approximately forty percent of the rate of productivity growth is attributable to technology transfer from other countries. Not only do high levels of domestic R\&D and educational attainment stimulate the growth of total factor productivity, but also the returns are significantly higher for industries operating below the international technological frontier. They interpret these findings as evidence that both $R \& D$ and education have twin effects; they stimulate the rate of domestic innovation and they increase the capacity of industries to absorb ideas from the overseas technological leaders.

\section{Implications for Growth and the Costs of an Ageing Population}

The capacity of the working-age population to support an increasing elderly population depends not only on changes in productivity but also on changes in labour force participation. This section attempts to quantify the extent to which rising education and lowered fertility are likely to offset the effects of an ageing population by promoting faster productivity growth and higher participation.

We start with a decomposition of GDP per capita (output averaged across the total population) into two components: output per working-age person, and the dependency rate.

$$
\frac{Y}{\text { Pop }}=\frac{Y}{\text { Popw }} \div \frac{\text { Popw }+ \text { Popdep }}{\text { Popw }}
$$

In this identity, Y represents GDP. Pop is the total population, composed of Popw, the working-age population, and Popdep, the dependent population. The last term in equation (1) is equal to ( $1+$ the dependency ratio). 
Taking logarithms of both sides and differentiating with respect to time, we derive the result that:

Growth of GDP per capita = growth rate of output per working-age person - growth rate of $(1+$ dependency ratio)

The total dependency ratio, as listed in Table 1 , is projected to rise from 48 per cent to 64 per cent by 2042. This is equivalent to an annual average growth rate of 0.0026 in the term (1+dependency ratio). In other words, the ageing of the Australian population implies that the annual growth rate of GDP per capita over the next forty years will be one quarter of a percentage point below the growth rate of output per working-age person.

It is useful to further decompose output per working-age person into the familiar economic concepts of productivity, the participation rate and the unemployment rate:

$$
\frac{Y}{\text { popw }}=\frac{Y}{H} \times \frac{H}{E} \times \frac{L}{\text { popw }} \times \frac{E}{L}
$$

The additional variables are aggregate hours worked $(\mathrm{H})$, employment $(\mathrm{E})$ and the labour force (L). Using this identity, we can decompose the rate of growth of output in terms of the growth rates of the four component ratios:

Growth of output per working-age person

$=\quad$ growth of hourly labour productivity $(\mathrm{Y} / \mathrm{H})$

$+\quad$ growth of average hours per worker (H/E)

$+\quad$ growth of labour force participation (L/popw)

- $\quad$ change in the unemployment rate ${ }^{1}$

For the purposes of our projections over the next forty years, we ignore changes in the unemployment rate. Whilst the unemployment rate rose sharply in the 1970s, there has been no clear trend since. Moreover, even if the unemployment rate were to rise or fall by as much as four percentage points over the next forty years, that would contribute only one tenth of a percentage point to the annual average rate of growth of real output. The most important factors that will determine output levels in forty years time are the growth rates of productivity and of the supply of hours of labour per person of working-age. The supply of hours is the product of average hours of work and labour force participation, terms (ii) and (iii) in equation (4). We examine these factors in turn.

\section{Labour Productivity and Increasing Levels of Human Capital}

Before considering the impact of human capital, we look at the growth record for GDP per capita and for labour productivity over the past thirty years both in the whole economy and in the market sector. Summary data are given in Table 3.

1 Here we use the relationship that $\mathrm{E} / \mathrm{L}=$ (1-ur), where ur is the unemployment rate, and the first-order approximation: $\mathrm{dlog}((1-\mathrm{ur}) / \mathrm{dt}=-\mathrm{d}(\mathrm{ur}) / \mathrm{dt}$. 
Table 3: Average Rates of Growth of GDP per Capita and Labour Productivity (per cent, per year)

\begin{tabular}{|c|c|c|c|c|c|}
\hline & & $\begin{array}{c}1971 / 72 \text { tc } \\
2001 / 02\end{array}$ & $\begin{array}{c}1971 / 72 \text { to } \\
1981 / 82\end{array}$ & $\begin{array}{c}1981 / 82 \text { to } \\
1991 / 92\end{array}$ & $\begin{array}{c}1991 / 82 \text { to } \\
2001 / 02\end{array}$ \\
\hline \multirow[t]{2}{*}{ Whole Economy } & Real GDP per capita & $1.9 \%$ & $1.6 \%$ & $1.2 \%$ & $2.7 \%$ \\
\hline & \multicolumn{3}{|c|}{ Gross product/hour worked ${ }^{1}$} & $1.1 \%$ & $2.1 \%$ \\
\hline Market Sector & Output per hour & $2.2 \%$ & $2.6 \%$ & $1.5 \%$ & $2.6 \%$ \\
\hline
\end{tabular}

1. Series starts $1978 / 79$

Source: National Accounts (ABS 5204.0)

Growth in real GDP per capita has averaged 1.9 per cent per year since 1971, falling slightly in the 1980s but recovering strongly in the 1990s. However, this is not a good measure of labour productivity since it is influenced by changes in both the participation rate and the dependency rate. Gross product per hour worked in the whole economy has been growing somewhat slower than per capita output. This is still an imperfect measure of labour productivity because of problems in the measurement of non-marketed services — particularly for the public sector where the Australian Bureau of Statistics adopts the practice of attributing zero productivity growth. The most reliable measure is for the market sector, where we observe a thirty-year average growth rate of 2.2 per cent per year.

Figure 2: Labour Productivity and GDP per capita, 1971/2 to 2001/2

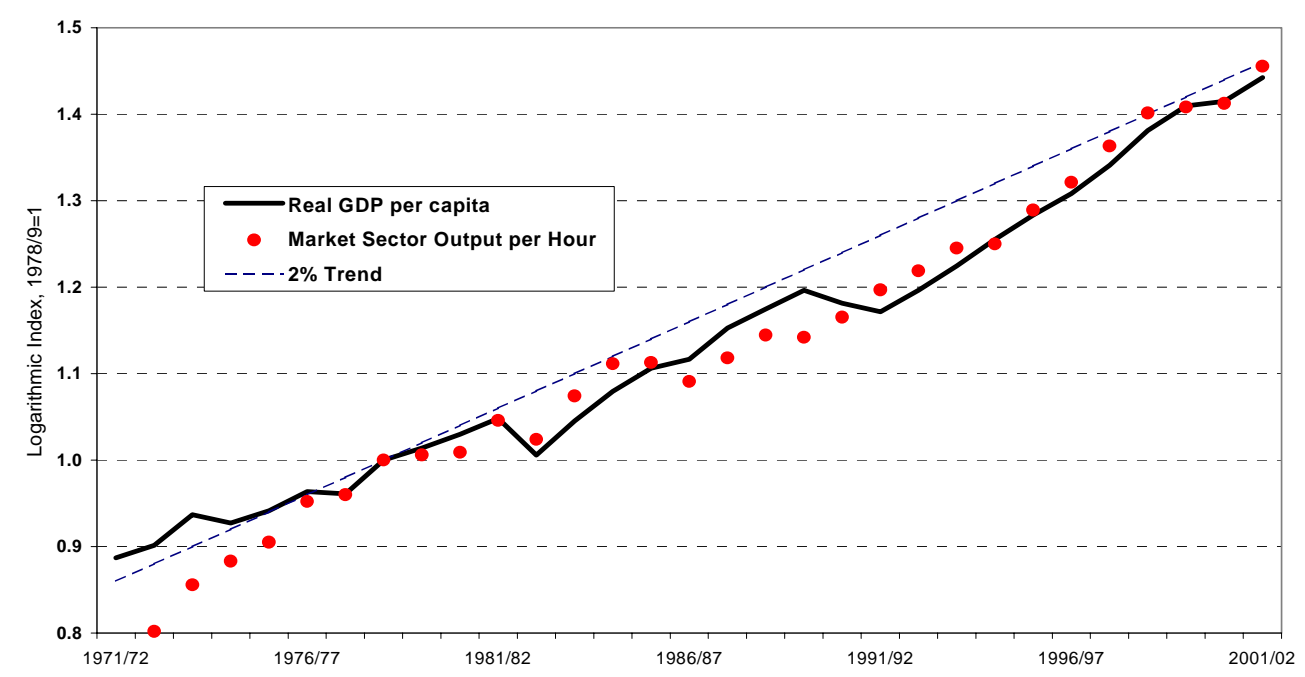

Source: National Accounts (ABS 5204.0). All series indexed to 100 in 1978/79.

In Figure 2 we display time series indexes of market sector productivity and real GDP per capita, along with a 2 per cent illustrative trend line projected from 
1978/79. Note that the indexes are scaled logarithmically, so a straight line represents a constant rate of proportional growth and a steeper line represents a faster rate of growth. Whichever measure we use, we observe a similar pattern. Productivity growth fell in the 1980s before recovering strongly in the 1990s. Both GDP per capita and hourly productivity in the market sector have been growing at an average rate of 2 per cent per year since 1978/79, implying that changes in dependency have been exactly offset by changes in the supply of hours.

In considering whether the 2 per cent trend in productivity growth is likely to continue, we need to take account of changes in the educational attainment of the workforce. A useful, albeit incomplete, measure of the level of education of a cohort is given by the proportion of secondary school children who stay on to Year 12. This proportion more than doubled from 35 per cent in 1980 to over 70 per cent in the 1990s - see Figure 1. Particularly noteworthy is the huge rise in educational attainment of Australian girls. Close to 80 per cent of the current generation of young Australian women (born between 1975 and 1980) have completed Year 12 of their schooling. In their parents' generation, born between 1940 and 1950, less than one quarter of girls continued to Year 12.

Table 4: Level of Highest Educational Attainment Amongst Population Aged 20-64 in 2001, by Cohort

\begin{tabular}{ccccccc}
\hline $\begin{array}{c}\text { Age at } \\
\text { May 2001 }\end{array}$ & $\begin{array}{c}\text { Bachelor or } \\
\text { Postgraduate } \\
\text { Degree }\end{array}$ & $\begin{array}{c}\text { Diploma or } \\
\text { Certificate } \\
\text { III or IV } \\
\text { Thousands (per cent of cohort) }\end{array}$ & Year 12 & Year 11 & $\begin{array}{c}\text { Year 10 } \\
\text { and Below }\end{array}$ & TOTAL $^{1}$ \\
\hline \hline $55-64$ & 230 & 365 & 162 & 76 & 836 & 1669 \\
& $(14)$ & $(22)$ & $(10)$ & $(5)$ & $(50)$ & $(100)$ \\
$\mathbf{4 5 - 5 4}$ & 499 & 594 & 315 & 170 & 933 & 2511 \\
& $(20)$ & $(24)$ & $(13)$ & $(7)$ & $(37)$ & $(100)$ \\
$35-44$ & 572 & 529 & 435 & 240 & 849 & 2625 \\
& $(22)$ & $(20)$ & $(17)$ & $(9)$ & $(32)$ & $(100)$ \\
$\mathbf{2 5 - 3 4}$ & 686 & 685 & 628 & 231 & 564 & 2794 \\
& $(25)$ & $(25)$ & $(22)$ & $(8)$ & $(20)$ & $(100)$ \\
$\mathbf{2 0 - 2 4}$ & 190 & 258 & 595 & 101 & 198 & 1342 \\
& $(14)$ & $(19)$ & $(44)$ & $(8)$ & $(15)$ & $(100)$ \\
\hline \hline $\mathbf{2 0 - 6 4}$ & 2177 & 2431 & 2135 & 818 & 3380 & 10941 \\
& $(20)$ & $(22)$ & $(20)$ & $(7)$ & $(31)$ & $(100)$ \\
\hline
\end{tabular}

Note: $\quad 1=$ Excluding the small numbers of people recorded as Certificate I or II or not defined.

Source: ABS 6227.0 (2002): Education and Work, Australia, Table 10.

If the historically high school retention rates of the 1990s are maintained, and continue to have a flow-on effect into higher education, then the average level of education in the workforce will rise substantially over the next three decades. As 
shown in Table 4, we can predict the likely rate of increase by examining current levels of educational attainment among the working-age population.

Among the oldest of these cohorts, those aged between 55 and 64 in 2001, only one in seven has a university degree and one half never progressed beyond Year 10 at school (moreover, it is likely that a substantial proportion of these attained only primary education). With each successive cohort there is a progression to higher levels of attainment. Amongst the 25-34 age cohort, 80 percent have gone beyond Year 10 and the proportion with university degrees is nearly double that of their parents' generation.

The figures for completed degrees and diplomas amongst the 20-24 age group are lower than those of the 25-34 group because many of this group have not yet completed their studies. But we do know that 85 per cent of this younger cohort has progressed beyond Year 10. We predict the average years of educational attainment of this cohort by assuming that the proportions of those going beyond Year 10 to reach each of the higher grades are the same as the proportions observed for the 25-34 group.

Figure 3: Post-Year 10 Attainment and Estimated Average Years of Education, by cohort

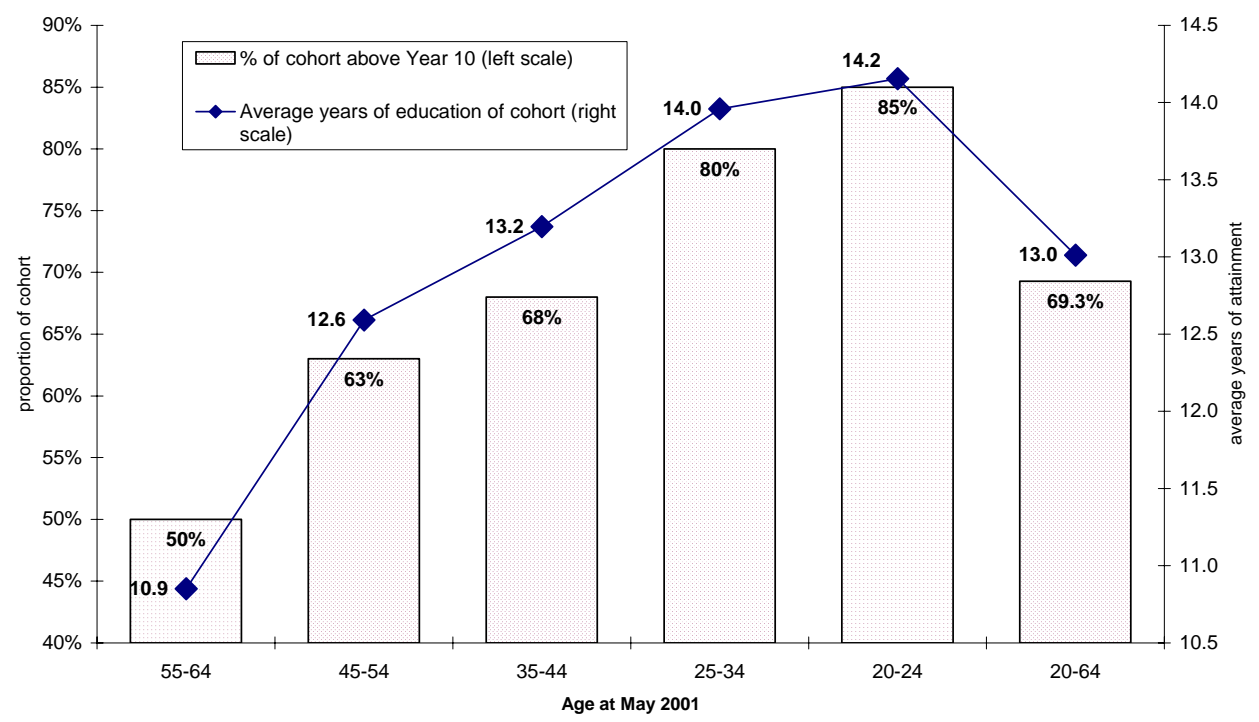

Source: Attainment data are from ABS 6227.0 (2002): Education and Work, Australia, Table 10. Estimates of average years of education assume an average of 3.7 years of education for the post-Year 10 group; for 'Year 10 or lower' assumed average years of education are as follows: 9 years if born before 1956; 10 years if born 1956-65; 11 years if born after 1966.

Estimates of the average years of education of each cohort are presented in Figure 3. While these estimates rely on assumptions about the average years of education associated with each cohort's attainments, the overall average of thirteen years of education matches closely the estimates in OECD (2001a). 
As the highly educated younger cohorts have replaced less educated older generations over the past forty years, average years of education in the workingage population has risen by more than three years according to OECD (2001a). We expect this process to continue, as the youngest cohort currently entering the labour force has an educational advantage of more than three years over the retiring cohort.

We must, however, expect that the rate of increase in educational attainment will slow relative to its pace since 1960. The growth of the proportion of each cohort that goes beyond Year 10 is slowing - as it must, given an absolute upper limit of 100 per cent. If current attainment levels persist into the future, the average years of education in the working-age population will rise from its current level of 13 years to reach a steady-state level of 14.2 years by 2041 .

This slow-down in the rate of increase of educational attainment does not necessarily imply a reduction in the contribution of education to economic growth over the next forty years. We have argued that there are two distinct mechanisms by which human capital affects growth. The first is the 'levels' effect by which an increase in the stock of human capital used in production increases the steady-state level of productivity, with a corresponding transitional growth effect. A slowdown in the rate of growth of educational attainment implies that this contribution to growth will diminish. But the second mechanism is the 'growth effect', by which a higher stock of human capital enables more rapid technological progress. Since the average stock of human capital over the next 40 years will be higher than the average over the past 40 years, the growth effect implies an acceleration of productivity.

In Table 5 we summarise our calculations of these two effects, comparing estimates of the contribution of education over the past forty years with its expected contribution over the next forty years.

The reduction in growth due to the slowdown in the rate of growth of educational attainment (the level effect) is more than offset by the growth effect resulting from the increased stock of human capital. The net effect of expected changes in the educational attainment of the adult population is to increase the annual rate of productivity growth by 0.22 percentage points over the next forty years. This is a conservative prediction in that we have used the lower of the estimated growth coefficients reported in Table 2 and we have assumed no further rise in years of educational attainment amongst young Australians.

\section{The Supply of Hours}

There are two components to trends in labour supply: the participation rate, defined as the ratio of the labour force to working-age population, and the average hours worked per employee. The product of these two ratios is the supply of hours per person of working-age.

Data from Australian Bureau of Statistics (2003) tells the following story for the supply of labour amongst persons aged 15-64 over the period 1980 to 2002. Falling male participation was more than offset by a strong rise in female 
participation, leading to an increase in overall participation from 69 per cent to 75 per cent. While average hours of work fell slightly for both men and women, the supply of hours per person of working-age rose from 24.2 hours to 25.2 hours per week. This represents a rate of growth of 0.2 per cent per year.

Table 5: Estimated Impact of Rising Education on Productivity Growth

\begin{tabular}{l|c|c}
\hline & $\mathbf{1 9 6 0 - 2 0 0 0}$ & $\mathbf{2 0 0 0 - 2 0 4 0}$ \\
\hline $\begin{array}{l}\text { Increase in average years of education of } \\
\text { the working-age population }\end{array}$ & 3.4 years & 1.2 years \\
\hline \multicolumn{1}{c|}{ Predicted effects on the annual percentage rate of growth of productivity } \\
\hline $\begin{array}{l}\text { 'Transitional Level effect' } \\
=0.2 \text { x change in years of education over } \\
\text { a forty year period }\end{array}$ & $0.2 \times 3.4=0.68$ & $0.2 \times 1.2=0.24$ \\
\hline $\begin{array}{l}\text { 'Long-run Growth effect' }=0.3 \times \\
\text { [(average years of education 2000-40)- } \\
\text { (average years of education 1960-2000)] }\end{array}$ & & $0.3 \times 2.2=0.66$ \\
\hline $\begin{array}{l}\text { Predicted change in productivity growth } \\
\text { rate relative to previous period }\end{array}$ & & $0.24+0.66-$ \\
\hline
\end{tabular}

Notes: 1 . The 1960-2000 increase is taken from OECD (2001a) which shows average years of schooling increasing from 9.84 in 1960 to 12.88 in 1990 and to 13.01 in 1995 . We assume that the increase 1995-2000 is the same as the increase 1990-95. The increase 2000-2040 is a projection based on the assumption that educational attainment levels of future cohorts entering the adult population are maintained at their 2001 current levels, 14.2 years.

2. Predicted effect on annual productivity growth over forty years, using an estimate of an 8 per cent rise in the level of steady-state output per effective worker for each additional year of average education in the workforce (see discussion in previous section).

3. This is the predicted effect on long-run rate of productivity growth from the change in the average level of education between each period, using the lower of the estimates from Table 2 of 0.3 percentage points for each additional year of average education.

\section{Implications for Growth in Output per Person}

The relationship between annual growth rates of productivity, labour supply, and output per person are displayed in Table 6, based on the growth accounting relationships of equations (2) and (4). The three rows of the table represent pessimistic, baseline and optimistic scenarios. The baseline scenario (the shaded second row) assumes that the rate of labour productivity growth is unchanged from its average over the past 25 years (2.0 per cent per year). We have argued that this is a conservative assumption, since increasing levels of education suggest 
an increase in the rate of productivity growth. The baseline scenario also assumes no further increase in the supply of hours of labour per working-age person.

Table 6: Scenarios for Rates of Growth in Output per Person (per cent, per year)

\begin{tabular}{|c|c|c|c|c|c|}
\hline & $\begin{array}{c}\text { assumed growth } \\
\text { of hourly labour } \\
\text { productivity }\end{array}$ & $\begin{array}{l}\text { assumed growth } \\
\text { in supply of } \\
\text { hours of labour } \\
\text { per person of } \\
\text { working age }\end{array}$ & $\begin{array}{c}\text { growth in } G D P \\
\text { per person of } \\
\text { working-age }\end{array}$ & $\begin{array}{c}\text { growth in } \\
(1+\text { dependency } \\
\text { ratio })\end{array}$ & $\begin{array}{l}\text { growth in GDP } \\
\text { per capita }\end{array}$ \\
\hline & (i) & (ii) & (i) + (ii) $=$ (iii) & (iv) & (iii) $-(\mathrm{iv})=(\mathrm{v})$ \\
\hline 1. & 1.5 & 0 & 1.5 & 0.26 & 1.24 \\
\hline 2. & 2.0 & 0 & 2.0 & 0.26 & 1.74 \\
\hline 3. & 2.2 . & 0.2 & 2.4 & 0.26 & 2.14 \\
\hline
\end{tabular}

The 'optimistic' scenario, in the third row of the table, factors in the effects on productivity of rising, albeit decelerating, levels of education. Using the estimates derived in Table 5, this implies productivity growth of 2.2 per cent per year. We also allow for the strong trend in female labour force participation to continue to drive the overall supply of hours per working-age person at the average rate of 0.2 per cent per year that has obtained since 1980 .

Working with our baseline scenario, the growth rate of GDP per capita is predicted to grow at 1.74 per cent per year - slightly slower than the 2 per cent average rate of growth over the past few decades because of the expected rise in dependency rates. Under our more optimistic scenario, the benefits of increasing levels of human capital are predicted to outweigh the dependency effect, leading to a per capita growth rate of 2.14 per cent per year.

The pessimistic scenario allows for adverse changes in Australia's institutional or policy settings, which might have the effect of reducing labour productivity growth. For example, policy changes that discouraged investment could lead to a slowdown in capital accumulation. A slowdown in labour force growth could reduce productivity growth in the face of scale economies or, as discussed by Cutler, Poterba et al. (1990), if an ageing workforce loses 'dynamism'. Allowing for a productivity slowdown of 0.5 percentage points below current trends, with no increase in the average supply of hours, per capita GDP growth would be 1.24 per cent per year.

These findings can be compared with the predictions of Guest and McDonald (2001). Their measure of average living standards, which is adjusted for the extra needs of the elderly and takes account of the projected ageing of the population, rises at an average annual rate of 1.2 per cent per year. Taking account of the impact of rising levels of human capital on productivity and labour supply, we suggest that a more optimistic scenario is likely. 
It is also of interest to examine the likely changes in real wages of the working-age population, taking into account the prediction of the Intergenerational Report that over the next forty years the fiscal burden of an ageing population may require an extra 5 per cent of GDP. We factor this into our calculations as a rise in the tax rate from 30 per cent to 35 per cent of GDP. Our results are presented in Table 7. We assume that real wage growth is the same as real output growth, ignoring any changes in factor shares or in the terms of trade.

\section{Table 7: Growth in Real Incomes of the Working-age Population over} Forty Years

\begin{tabular}{|c|c|c|}
\hline & $\begin{array}{c}\text { annual growth in GDP per cumulative growth in pre- } \\
\text { person of working-age tax income over } 40 \text { years }\end{array}$ & $\begin{array}{c}\text { cumulative growth in post- } \\
\text { tax income with } 5 \% \\
\text { additional levy }{ }^{1}\end{array}$ \\
\hline 1. & 1.5\% p.a. & $68 \%$ \\
\hline 2. & 2.0\% p.a. & $105 \%$ \\
\hline 3. & 2.4\% p.a. & $140 \%$ \\
\hline \multicolumn{3}{|c|}{ Assuming a rise in the average tax rate from 30 per cent to 35 per cent. } \\
\hline \multicolumn{3}{|c|}{$\begin{array}{l}\text { Working with our baseline scenario, labour productivity and real incomes } \\
\text { be substantially more than double current levels in forty years time. An } \\
\text { ease in taxation of five percentage points of GDP to finance the rise in public } \\
\text { nditures, as forecast by the Intergenerational Report (2001), implies a rise in } \\
\text {-tax income of } 105 \text { per cent. Even under a pessimistic scenario where labour } \\
\text { uctivity growth averages only } 1.5 \text { per cent per year, real after tax incomes } \\
\text { ld still increase by more than two-thirds. In our more optimistic scenario, the } \\
\text { post-tax income of the working-age population increases by } 140 \text { percent. }\end{array}$} \\
\hline
\end{tabular}

\section{Conclusions}

The past forty years have witnessed a huge increase in the educational attainment of young Australians, in particular young women. This shift in educational aspirations and achievement has had a profound effect on fertility and population growth. As women have attained higher levels of education, so their potential earnings have risen and they have chosen to increase their participation in the labour force. At the same time, parents have chosen to have fewer children but to invest more in their education. A continuing rise in educational attainment over the next forty years, as highly educated young people replace less educated retirees, can be expected to increase the rate of productivity growth.

The ageing of the Australian population is an inevitable result of the fact that the fertility rate has fallen and longevity has increased. This implies that in future the working age population will be supporting a much larger elderly population than at present. We have shown, however, that the ageing of the population is not at all likely to impoverish the next generation of working Australians. Whilst the 
working-age population is becoming smaller relative to the aged population, it is also becoming smarter and more productive and is increasing its supply of labour. Indeed, the very factor that has contributed to the decline in fertility, the rising educational attainment of young Australians, is the same factor that is likely to sustain rapid growth in productivity and income.

\section{References}

Ashenfelter, Orley and Alan B Krueger (1994), 'Estimates of the Economic Returns to Schooling from a New Sample of Twins’, American Economic Review 84(5):1157-1173.

Australian Bureau of Statistics (2003). 'Labour Force Australia’, Catalogue 6203.0

Barro, R. and G. Becker (1988), 'A Reformulation of the Economic Theory of Fertility', Quarterly Journal of Economics CIII(1):1-25.

Barro, R. and J. Lee (1994), 'Sources of Economic Growth', Carnegie Rochester Conference Series on Public Policy 40(June):1-46.

Barro, R. and X. Sala-i-Martin (1995), Economic Growth, New York; London and Montreal: McGraw-Hill.

Bassanini, A. and S. Scarpetta (2002), 'Does Human Capital Matter for Growth in OECD Countries? A Pooled Mean-Group Approach’, Economics Letters 74:399-405.

Becker, G. and H. Gregg Lewis (1973), 'On the Interaction between Quantity and Quality of Children’, Journal of Political Economy 81(2):s279-s288.

Becker, G., K. Murphy and R. Tamura (1990), 'Human Capital, Fertility, and Economic Growth’, Journal of Political Economy 98(5):S12-37.

Benhabib, J. and M. Spiegel (1994), 'The Role of Human Capital in Economic Development: Evidence from Aggregate Cross-Country Data', Journal of Monetary Economics 34(2):143-173.

Cigno, A. and F. Rosati (1996), 'Jointly Determined Saving and Fertility Behaviour: Theory and Estimates for Germany, Italy, UK and USA', European Economic Review 40:1561-1589.

Collins, C., J. Kenway and J. McLeod (2000), Factors Influencing Educational Performance of Males and Females in School and Their Initial Destinations after Leaving School, Commonwealth of Australia, Ausinfo, Canberra:

Commonwealth of Australia (2002), Government Budget Paper 5, 'Intergenerational Report'

Cutler, D., J. Poterba, L. Sheiner and L. Summers (1990), 'An Aging Society: Opportunity or Challenge?’, Brookings Papers on Economic Activity 1990(1):1-56.

Dowrick, S. and M. Rogers (2002), 'Classical and Technological Convergence: Beyond the Solow-Swan Growth Model’, Oxford Economic Papers 54:369-385.

Ehrlich, I. and F. Lui (1991), 'Intergenerational Trade, Longevity and Economic Growth', Journal of Political Economy 99(5):1029-1059. 
Frantzen, D. (2000), 'R\&D, Human Capital and International Technology Spillovers: A Cross-Country Analysis’, Scandinavian Journal of Economics 102(1):57-75.

Galor, O. and D. Weil (1996), 'The Gender Gap, Fertility and Growth', American Economic Review 86(13):374-387.

Griffith, R., S. Redding and J. Van Reenen (2000), 'Mapping the Two Faces of R\&D: Productivity Growth in a Panel of OECD Industries', London School of Economics, Centre for Economic Performance Discussion Paper 2457 (May):1-74.

Guest, R. and I. McDonald (2001), 'Ageing, Optimal National Saving and Future Living Standards in Australia’, Economic Record 77(237):117-134.

Lucas, R., Jr. (1988), 'On the Mechanics of Economic Development', Journal of Monetary Economics 22(1):3-42.

Mankiw, N., G. Romer and D. Weil (1992), 'A Contribution to the Empirics of Economic Growth’, Quarterly Journal of Economics 107(2):407-437.

McDonald, P. (2001), 'Low Fertility Not Politically Sustainable', Population Today 29(6):3,8.

Miller, P., C. Mulvey and N. Martin (1995), 'What Do Twins Studies Reveal About the Economic Returns to Education? A Comparison of Australian and U.S. Findings', American Economic Review 85(3):586-599.

Nelson, R. and E. Phelps (1966), 'Investment in Humans, Technological Diffusion, and Economic Growth’, American Economic Review 56(1-2):69-75.

OECD (2001a), 'Education Online Database’, http://www.oecd.org/.

OECD (2001b), 'Fiscal Implications of Ageing: Projections of Age Related Spending', Economics Department Working Paper 305.

OECD (2003), ‘Ageing Societies and the Looming Pension Crisis', OECD Reading Material June (OECD documents: www.oecd.org).

Preston, A. (1997), 'Where Are We Now with Human Capital Theory in Australia?', Economic Record 73(220):51-78.

Romer, P. (1990), 'Endogenous Technological Change', Journal of Political Economy 98(5):S1971-1102.

Rosenzweig, M. (1990), 'Population Growth and Human Capital Investments: Theory and Evidence’, Journal of Political Economy 98(5):s38-s70.

The authors thank the editor and the two referees for their helpful comments and suggestions. 


\title{
The Demographic Gift in Australia
}

\author{
Natalie Jackson and Bruce Felmingham
}

$\mathrm{T}$

The demographic gift describes the effects generated by the coincidental occurrence of declining birth rates and increasing life expectancy, a legacy of the phenomenon known as 'the demographic transition'. The gift refers to the relatively brief (2-3 decades) period during which the proportion of the population aged 15-64 years is at its maximum; correspondingly the proportions dependent at the younger and older ages are at their minimum. At this point in the demographic transition, the working age population also grows considerably faster than the total population.

The relevance of these demographic concepts to economic analysis is the income effects of the gift itself, and it is this attribute that has motivated the study of the demographic gift in many developing and newly developed countries (Birdsall, Kelley and Sinding, 2001; Bloom and Canning, 2003; Mason, 2003). Interestingly, the phenomenon has received much less scholarly interest in the developed countries, despite it having delivered to them empirically verifiable economic benefits. Ironically, it may only be with the emergence of the gift in the developing countries and its simultaneous loss in the developed countries that the phenomenon will be afforded the recognition it deserves.

The objective of this study is to assess the magnitude of the demographic gift in Australia, and the impact of its impending loss. It also considers the effect of the baby boom (1946-65) and baby 'bust' (1966 to late-1970s) in prolonging the period of gift. The baby boomers are now moving through the highest income earning groups, namely, the age groups 35-44 years and 45-54 years. They are followed by a band of significantly extended 'baby boom echo' cohorts born in the period 1969-72 who are only just approaching the first of these highest incomeearning age groups. Inappropriately defined as the period of the 'baby bust', the late 1960s and 1970s saw dramatically falling birth rates per woman, but in 1971 also saw the birth of Australia's largest-ever birth cohort - the multiplicative effect of increased numbers of men and women (the 'leading edge' baby boomers) reaching reproductive age.

These inter-related phenomena are evident in Figure 1, which illustrates the differing trends of the total fertility rate (average births per woman) and cohort size (actual birth numbers). It is our central thesis that the passage of the echo or baby bust cohorts into and through the highest income earning age groups over the next several decades will significantly ameliorate Australia's loss of 'the gift' as it has been conventionally defined.

Natalie Jackson is Senior Lecturer in Social Demography, School of Sociology and Social Work, and Bruce Felmingham is Reader in Economics, School of Economics, both at the University of Tasmania 
Figure 1: Total Fertility Rates, Cohort Size, the Baby Boom and 'Baby Bust', Australia, 20th Century

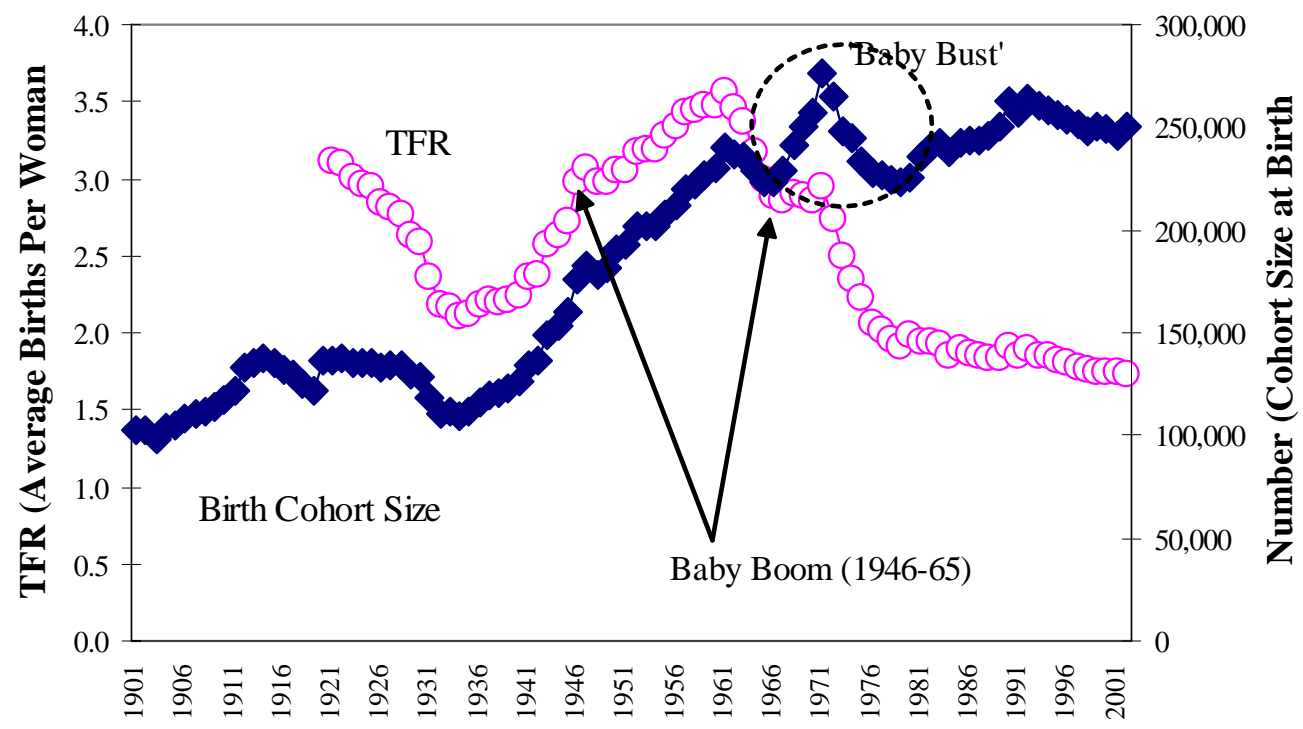

Source: ABS Births, various years

Another contribution of this study is that the size of the demographic gift is assessed at both national and regional levels. Our extension to cover the individual States and Territories of the Australian Commonwealth follows Jackson and Felmingham (2002), who find that the timing and speed of the structural ageing process differs markedly across the Australian States and Territories. Regional disparities carry substantial policy significance, particularly for institutions and fiscal transfer arrangements such as those allocated by the Commonwealth Grants Commission and to the States Grants Commissions.

A number of caveats must be entered at the outset. First, the size of Australia's demographic gift has been and will continue to be influenced by international migration, which in Australia typically augments each birth cohort as it passes through its twenties and thirties. The 1971 cohort, for example (currently aged 32 years), numbered 276,362 at its birth, and 315,666 in 2002. However, over the longer term, migration tends to have a similar impact on each cohort, and so it has minimal effect on the overall age structure (Kippen and McDonald, 2000). In 2003 the 1971 cohort remains Australia's largest, and it is projected to remain so for a further three decades.

Second, in considering the future loss of the gift, the study uses the age-sex specific income distribution for 2001 and projects it forward according to the Australian Bureau of Statistics high variant (Series I) population projections (ABS, 2000). This methodology illustrates what would occur if there were no change in the income distribution over the base year, and the high variant 
assumptions regarding births, deaths and migration prevail. Accordingly, there is no intention to imply that these economic projections are 'forecasts' of future aggregate earnings. Indeed it is our thesis that there will be significant changes to the age-sex income distribution as the demographic trends we outline here unfold, not least those affecting the ratio of labour market entrants to exits, which in all probability will see substantial improvements in labour market demand for the young.

Third, to advance this study, the age distribution is treated as an exogenous variable, although the related significance of explaining the various causes and dynamics of the gift is an acknowledged issue. In this study, the link between the resulting size of the gift and its economic manifestation is confined to an examination of the correlation between the size of the gift and per capita GDP, and to its impact on aggregate earnings.

\section{Australia’s Demographic Gift}

In its original formulation, the demographic gift is derived from demographic events that increase the proportion of the population aged 15 to 64 . By convention, these are primary working age (and therefore primary income earning) people. The limiting ages of this conventional measure of the working age population are contestable. The lower limit of 15 years does not account for increasing participation in senior secondary or tertiary education, while the upper limit ignores the recent tendency towards early retirement. However, to counter these arguments, many school and tertiary students undertake part time and casual work, reinforcing the case for an arbitrary lower age limit of 15 years. Pressures for people to work longer are also now reversing the trends toward early retirement, making 65 years of age an appropriate benchmark for a future-oriented study. Finally, international labour market data, such as that generated by the International Labour Office, the OECD, United Nations, and World Bank are typically based on a 15-64 year old (or 15+ year) 'working age' population. The case for changing this conventional view of the working age population is not strong enough to counter the benefits of maintaining a basis for comparison with other studies.

The historical record and projections to 2051 of the proportion of the Australian population aged 15-64 years are shown in Figure 2, along with an illustration of 'the gift' in terms of GDP per capita over the years 1959-2002.

The data over the period 1901 to 2002 show that the proportion of Australia's population in the primary working age group peaked in 1943 when 68.2 per cent of the population was of working age. The dip evident over the 1960s reflects the effects of the ensuing baby boom in reducing the proportion in the working age population: the proportion of the population aged 0-14 years peaked at 30 percent in 1961. The projections to 2051 indicate that the working age proportion will reach a second and final peak about 2008, at around 67.8 percent of the population. The decline in the projected working age proportion thereafter will by 2051 reduce the proportion below 60 per cent, some 2.2 per cent below its trough 
in 1961. These 'otherwise indicative' trends should be considered fairly robust over the next few decades at least, as most of the people they represent are already in the population age structure.

Figure 2: The Demographic Gift (Percentage Aged 15-64 Years) 19012051, and GDP per capita (1960-2002, Indexed to 1960)

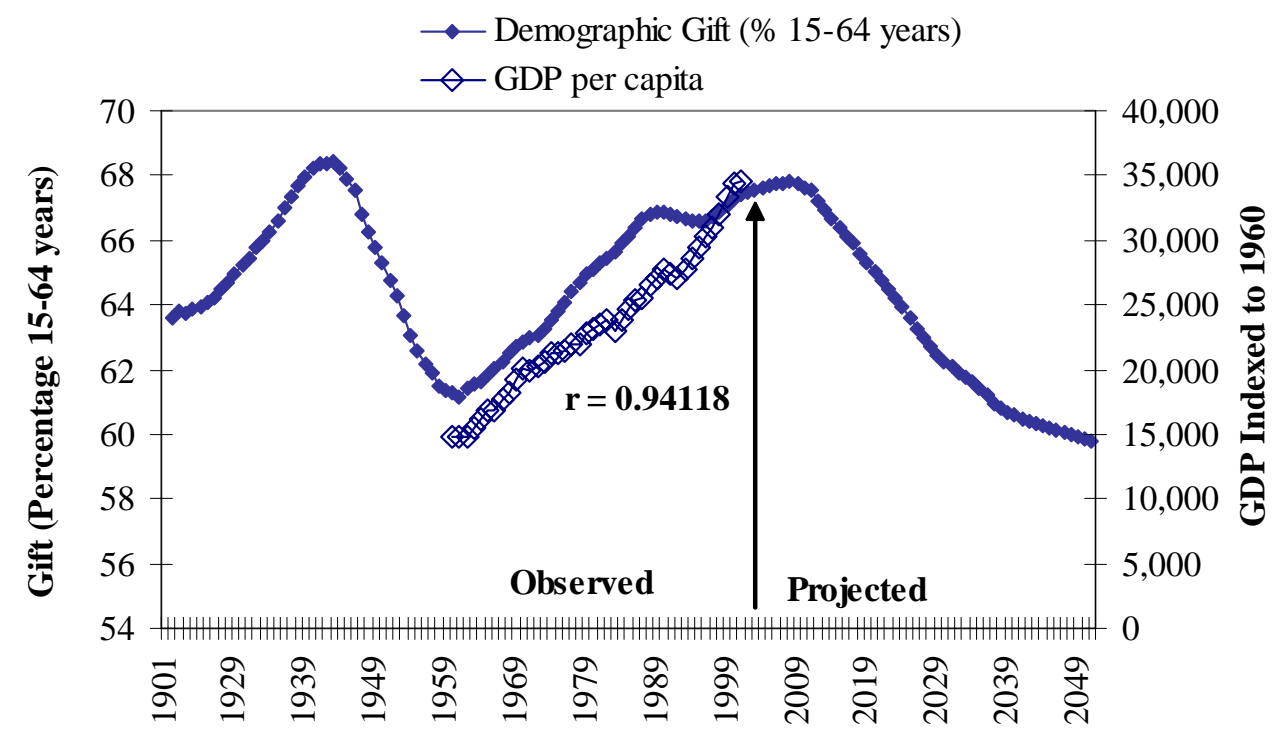

Note: Projections of the working age proportion over the period 2003 to 2051 are based on the high variant assumptions underpinning the Australian Bureau of Statistics (ABS, 2000) Series 1 population projections: a constant annual net migration gain of 110,000, a constant Total Fertility Rate of 1.75 from 2009, and life expectancy increasing by approximately 1 year for every 10 years projected.

Source: 1901-2001 ABS Estimated Resident Population; 2002-2051 ABS Population Projections 1999-2051 Catalogue 3222.0, Series I; ABS Leading Indicator Series

Some indication of the relationship between these working age population trends and key economic variables such as income (earnings) is provided in the simple correlation analysis of the proportion of the population aged 15-64 years and GDP per capita, shown on the graph as $r=0.94$. The correlation is striking, and while GDP per capita is influenced by many other economic factors it is clear that a prima facie case exists for a further analysis of the population/economic activity nexus using Australian data.

The results of other Australian studies focussed on the nexus between demographic and macroeconomic characteristics are mixed. This view certainly applies to the recent debate about population ageing and aggregate saving in Australia. The genesis of this debate is to be found in the work of Fitzgerald 
(1993), later supported by Argy (2001) and Wood (2001) who posit that Australians are not saving enough presently to support an older Australian population in future and that some policy intervention is required. However, Guest and McDonald (1998), using their own model of optimal saving, conclude that Australian households were thrifty over the period 1960-1961 to 1973-74, over-saving in relation to optimal savings by 5.3 percent. Conversely the years from 1974-75 to 1994-95 were characterised by undersaving, but this was only 1.7 per cent below the optimal level. The same authors - Guest and McDonald (2001) - explore the specific effects of population ageing on Australia's living standards. They find that population ageing puts a slight downward pressure on living standards until 2050, but they also conclude that age-adjusted living standards will continue to increase, although at a reduced annual rate of 1.2 percent. In summary, the Guest and McDonald findings are that the effects of structural population ageing on living standards are small and, contrary to their earlier recommendations, they do not recommend policy intervention. The following analysis, which assesses the personal income effects of the gift and its impending loss, may assist in explaining Guest and McDonald's results. It also contributes to the argument regarding the need for policy intervention.

Figure 3 shows the impact of changes in age structure on aggregate earnings (our proxy for personal income), first across the 1976-2001 period, and then projected from 2001 to 2051 . However, before discussing the results, we note the method by which we obtained them. For the first period (1976-2001), aggregate median annual incomes by age and sex were derived from Census data (ABS 'unpublished' customised database) for each of the six observations 1976-2001 (data available on request). Using the technique of direct standardisation (see Pollard, Yusuf and Pollard, 1974:64-67), the age-sex structure was then held constant at its 1976 percentage distribution, and applied to the underlying age-sexspecific income data for each observation to show what the aggregate annual earnings for each observation would have been if the age-sex structure had remained constant at its 1976 distribution. The difference between the two resulting aggregate earnings values is the effect of actual changes in the age structure across the period.

For the second period (2001-2051), the median weekly incomes for 2001 for each age-sex group were held constant at their 2001 dollar values and projected to 2051 by applying to them the numbers projected to be in each age-sex group at each observation. The results were then summed and multiplied by 52 (weeks) to give weighted aggregate annual earnings for each observation. The 2001 age-sex income data were then separately projected to 2051 by holding the age-sex structure constant at 2001 (percentage distribution) values, and applying it to the projected total population size for each observation. This latter process (a combination of direct and indirect standardisation) derived the number that would be in each age-sex group at each year if there were no changes to the age structure, and the aggregate weekly earnings of each age-sex group under these conditions. The difference between the two resulting aggregate earnings values is the dollar effect of projected changes in the age structure across the period. 
The resulting data presented in Figure 3 show a small but positive contribution from age structure to aggregate earnings across the 1976-2001 period, peaking at 3.2 per cent in 1996 and then reducing to 2.5 per cent in 2001. In dollar terms these contributions appear more significant - in 2001, for example, the change in age structure over 1976 contributed around 8.4 billion dollars to aggregate income. The projections to 2051 then show a slowly increasing negative contribution, reaching 1.9 per cent by 2011 and 8.6 per cent by 2051 . That is, by 2051, if the age-sex income distribution extant in 2001 and the assumptions underlying the high variant population projections were to prevail, population ageing would reduce aggregate earnings by around 8.6 per cent over what they would be if the age structure remained constant. At 2001 dollar values this amounts to a reduction of some 37.4 billion dollars by 2051. However, it should be noted that this reduction will occur alongside an overall growth in aggregate earnings - the overall effect of an increase in the size (as opposed to proportion) of the working age population, albeit at a decelerating rate. Ceteris paribus, aggregate earnings will increase from their present 312 billion dollars, to around 439 billion dollars by 2051. Again we reiterate the point that this analysis includes consideration of projected demographic change only.

\section{Figure 3: Percentage Contribution of Age Structure to Aggregate Earnings, 1976-2001 and Projected 2001-2051, Australia}

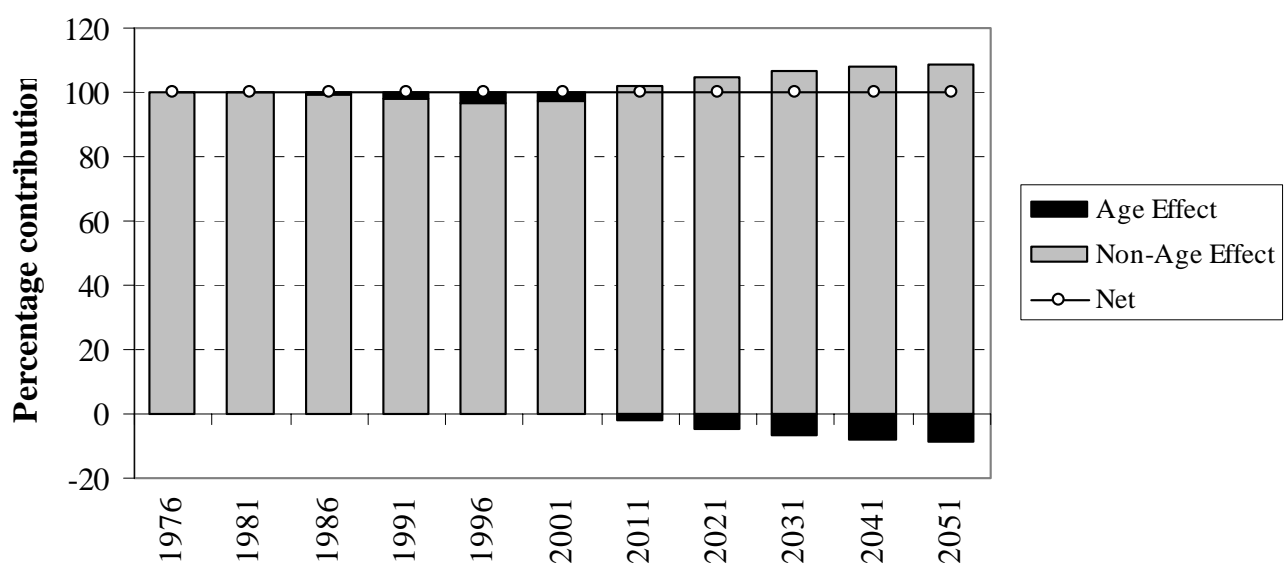

Source: Authors: 1976-2001; ABS customised database; 2001-2051; ABS (2000) Population Projections, Catalogue 3222.0 Series I; and ABS Basic Community Profiles, Catalogue 2001.0.

Changes in the Australian age structure will thus act to reduce aggregate earnings over what they would have been if the age structure were to remain constant. The trend will accelerate from 2011, the year in which the first of the 
baby boomers will reach age 65 and begin their en masse passage out of the primary working age group. Accordingly, we can conclude that on this conventional understanding and measurement of the demographic gift, its peak dividends have been realised.

We note here a further minor caveat. For various reasons the analyses for the two periods were carried out separately, using two different earnings databases, and bought together for the purpose of more clearly explicating the shift from positive to negative contribution. This methodology introduces a slight but not significant disjunction at the 2001 locus. The approach is justified by the practical difficulties of forecasting how factors affecting the real values of weekly income might change.

\section{The Demographic Gift at State and Territory Level}

The same methodology as was applied to Australia overall can be applied to each State and Territory. However, for the present purposes, an analysis of the projected period 2001-2051 above will suffice. Using the same ABS (2000) high variant projections, but this time for States and Territories, Table 1 shows the relative contribution to (or more accurately, reduction of) aggregate earnings made by age structure.

The findings reflect the differing quantum and tempo of population ageing across the states and territories, a point that we elaborate further below. Tasmania, currently the fastest ageing region, sees a larger percentage (reduction) effect by 2011 than does any other region. However, the difference between Tasmania on the one hand, and South Australia, Victoria, and the currently younger, but soonto-age-faster ACT, on the other, is minimal, and, on the demographic assumptions underlying these high variant projections, Tasmania 'recovers' demographically, and soon experiences a relatively smaller effect on earnings than these regions. By 2021, the effect for Tasmania is somewhat smaller than for each of South Australia, Victoria, the ACT and New South Wales. Importantly, at each observation across the period, four States/Territories experience greater percentage reductions than does total Australia, and four experience less. This somewhat predictable outcome, which can be conceptualised as 'winners' and 'losers', is the one that we have been concerned to show: it is invisible in typical analyses of population ageing at the national level.

A second equally significant observation is evident in Table 1 . While the total aggregate earnings of Total Australia, the ACT, New South Wales, Queensland, Western Australia, and the Northern Territory continue to grow across the projection period, reflecting projected growth in their working age populations per se, those for South Australia and Tasmania peak and begin to decline from 2011 and 2021 respectively, the same occurring for Victoria from 2031. Again the ceteris paribus caveat must be noted. 
Table 1: Projected Effect of Population Ageing on Aggregate Annual Earnings

\begin{tabular}{|c|c|c|c|c|c|c|}
\hline & 2001 & 2011 & 2021 & 2031 & 2041 & 2051 \\
\hline \multicolumn{7}{|l|}{ TOTAL AUSTRALIA } \\
\hline Percentage Effect (\% reduction) & 0.0 & -1.9 & -4.4 & -6.6 & -7.9 & -8.6 \\
\hline Value reduction (\$ Billions) & 0.0 & -6.7 & -16.6 & -26.8 & -33.5 & -37.7 \\
\hline Aggregate Annual Income* (\$ Billions) & 312.3 & 349.9 & 379.8 & 404.2 & 424.0 & 439.6 \\
\hline \multicolumn{7}{|l|}{ TASMANIA } \\
\hline Percentage Effect (\% reduction) & 0.0 & -2.2 & -4.2 & -5.9 & -7.1 & -7.8 \\
\hline Value reduction (\$ Billions) & 0.0 & -0.1 & -0.3 & -0.4 & -0.4 & -0.5 \\
\hline Aggregate Annual Income* (\$ Billions) & 6.3 & 6.5 & 6.6 & 6.5 & 6.2 & 5.9 \\
\hline \multicolumn{7}{|l|}{ SOUTH AUSTRALIA } \\
\hline Percentage Effect (\% reduction) & 0.0 & -2.0 & -4.7 & -7.0 & -8.3 & -9.0 \\
\hline Value reduction (\$ Billions) & 0.0 & -0.5 & -1.1 & -1.6 & -1.8 & -1.8 \\
\hline Aggregate Annual Income* (\$ Billions) & 22.0 & 22.7 & 22.7 & 22.2 & 21.4 & 20.2 \\
\hline \multicolumn{7}{|l|}{ VICTORIA } \\
\hline Percentage Effect (\% reduction) & 0.0 & -2.1 & -4.8 & -7.4 & -8.9 & -9.6 \\
\hline Value reduction (\$ Billions) & 0.0 & -1.8 & -4.1 & -6.5 & -7.8 & -8.3 \\
\hline Aggregate Annual Income* (\$ Billions) & 77.4 & 83.1 & 86.2 & 87.5 & 87.7 & 87.0 \\
\hline \multicolumn{7}{|l|}{ ACT } \\
\hline Percentage Effect (\% reduction) & 0.0 & -2.0 & -4.9 & -7.8 & -9.7 & -11.1 \\
\hline Value reduction (\$ Billions) & 0.0 & -0.1 & -0.3 & -0.5 & -0.6 & -0.8 \\
\hline Aggregate Annual Income* (\$ Billions) & 6.9 & 7.9 & 8.7 & 9.4 & 10.0 & 10.5 \\
\hline \multicolumn{7}{|l|}{ NEW SOUTH WALES } \\
\hline Percentage Effect (\% reduction) & 0.0 & -1.9 & -4.7 & -7.0 & -8.4 & -9.1 \\
\hline Value reduction (\$ Billions) & 0.0 & -2.3 & -6.0 & -9.6 & -11.9 & -13.3 \\
\hline Aggregate Annual Income* (\$ Billions) & 110.0 & 121.4 & 129.8 & 136.6 & 141.8 & 145.7 \\
\hline \multicolumn{7}{|l|}{ QUEENSLAND } \\
\hline Percentage Effect (\% reduction) & 0.0 & -1.6 & -3.6 & -5.5 & -6.7 & -7.4 \\
\hline Value reduction (\$ Billions) & 0.0 & -1.1 & -2.8 & -5.0 & -6.7 & -8.1 \\
\hline Aggregate Annual Income* (\$ Billions) & 55.5 & 67.6 & 79.3 & 90.0 & 99.8 & 108.6 \\
\hline \multicolumn{7}{|l|}{ WESTERN AUSTRALIA } \\
\hline Percentage Effect (\% reduction) & 0.0 & -1.5 & -4.0 & -6.2 & -7.5 & -8.3 \\
\hline Value reduction (\$ Billions) & 0.0 & -0.6 & -1.7 & -2.8 & -3.8 & -4.4 \\
\hline Aggregate Annual Income* (\$ Billions) & 30.5 & 36.2 & 41.2 & 45.8 & 49.9 & 53.6 \\
\hline \multicolumn{7}{|l|}{ NORTHERN TERRITORY } \\
\hline Percentage Effect (\% reduction) & 0.0 & -0.9 & -1.9 & -3.2 & -4.1 & -4.7 \\
\hline Value reduction (\$ Billions) & 0.0 & 0.0 & -0.1 & -0.2 & -0.3 & -0.4 \\
\hline Aggregate Annual Income* (\$ Billions) & 3.5 & 4.5 & 5.5 & 6.5 & 7.7 & 8.9 \\
\hline
\end{tabular}

Notes: *After reduction of ageing effect

- States and Territory Totals do not sum exactly to Total Australia due to rounding effects of using States, Territories and Total data separately.

Source: Calculated by the authors from ABS Basic Community Profiles 2001.0 Table B13 and ABS Population Projections 1999-2100 Catalogue 3222.0 
However, it is only when these two elements of the analysis are drawn together that we can begin to appreciate the full significance of the regionallydiffering changes in age structure. Were it not for their currently more rapid ageing, the aggregate earnings of Tasmania, South Australia and Victoria would not begin to decline in absolute terms for a full decade beyond those specified years. (These outcomes can be observed by adding rather than subtracting age effect to total aggregate earnings). At the same time, the substantially greater impact for the ACT - a reduction of 11.1 per cent by 2051 compared with 8.6 per cent nationally — is illustrative of the more rapid ageing that region is projected to experience from 2011.

Conceptualised in this manner, the regionality of population ageing in Australia has significant implications for each region's aggregate earnings - in some cases negative, in others, positive. However, here we must pause and ask if this formulation of 'the problem' is in fact the correct one? We turn to a consideration of a closely related index: the median individual, and where he or she is located in terms of their earning capacity.

\section{The Median Individual and the Duration of the Demographic Gift}

Presently in Australia, the age of the median person is 35.9 years. He or she was born in 1968, shortly after the peak of the baby boom, which occurred in 1961. Paradoxically, as indicated earlier, the current median individual was born prior to 1971 when the most populous of Australia's age cohorts was born. This paradox is explained by the momentum effect, which refers to the growth potential of the population age structure even as fertility declines. Increasing numbers of people continue to reach reproductive age in each successive year due in part to the higher fertility rates prevailing when they were born, and in part to increasing life expectancy. Even when fertility falls below the generational replacement rate of 2.1 births per woman, these distended cohorts continue for a time to produce successively larger numbers of children, because the size of the birth cohort is the combined effect of the birth rate and the numbers of women at reproductive age. In the Australian case, the birth rate had fallen to 2.9 births in 1971. However, by 1971, the first of the baby boomers had arrived at reproductive age, an effect that added a further three quarters of a million more women to the reproductive age group. So, although the birth rate per woman was lower, the increased number of reproductive age women delivered to Australia its largest birth cohort in 1971. Ironically, this momentum-derived cohort was born during the so-called baby bust, the period between the mid 1960s and 1970s when birth rates plummeted.

The economic importance of the median individual is that aggregate earnings are at their maximum when the median individual is in this highest income earning age group, and will decline as he/she moves through the age distribution to lower income groups. The median individual has only recently (in the year 2000) entered Australia's historically highest earning income age group (full time earnings), namely, the 35 to 44 year group. He or she will remain in this key age 
group until at least 2041 on the assumptions of the ABS medium variant projections, or 2051 on the high variant assumptions (ABS, 2000). This implies a period of 'concentrated gift' of a minimum 41 years for Australia overall. This association of age and income distribution at age 35-44 provides a different approach to measuring the income effects of the demographic gift generated by the momentum effect, as these effects are being sustained by the baby bust cohorts.

Table 2: Projected Shares of Working Age Population and Aggregate Weekly Earnings, By Age, Australia 2001-2051

\begin{tabular}{|c|c|c|c|c|c|c|}
\hline & 2001 & 2011 & 2021 & 2031 & 2041 & 2051 \\
\hline \multicolumn{7}{|l|}{$\begin{array}{l}\text { Percentage share of working } \\
\text { age population }\end{array}$} \\
\hline $15-19$ & 8.7 & 8.0 & 7.3 & 6.9 & 6.8 & 6.6 \\
\hline $20-24$ & 8.9 & 8.3 & 7.6 & 7.3 & 7.2 & 7.1 \\
\hline $25-34$ & 18.9 & 16.9 & 16.0 & 14.9 & 14.5 & 14.4 \\
\hline $35-44$ & 19.1 & 17.7 & 16.1 & 15.5 & 14.7 & 14.5 \\
\hline $45-54$ & 17.1 & 17.1 & 16.2 & 15.1 & 14.9 & 14.4 \\
\hline $55-64$ & 11.7 & 14.8 & 15.2 & 14.8 & 14.1 & 14.2 \\
\hline $65-74$ & 8.4 & 9.5 & 12.4 & 13.2 & 13.2 & 12.9 \\
\hline $75+$ & 7.1 & 7.7 & 9.2 & 12.3 & 14.7 & 16.0 \\
\hline TOTAL & 100.0 & 100.0 & 100.0 & 100.0 & 100.0 & 100.0 \\
\hline \multicolumn{7}{|l|}{$\begin{array}{l}\text { Percentage share of } \\
\text { aggregate weekly income }\end{array}$} \\
\hline $15-19$ & 1.0 & 1.0 & 0.9 & 0.9 & 0.9 & 0.9 \\
\hline $20-24$ & 8.2 & 7.8 & 7.3 & 7.2 & 7.1 & 7.1 \\
\hline $25-34$ & 24.8 & 22.6 & 21.9 & 20.8 & 20.5 & 20.4 \\
\hline $35-44$ & 25.3 & 23.8 & 22.3 & 21.9 & 21.1 & 20.9 \\
\hline $45-54$ & 22.5 & 22.8 & 22.2 & 21.1 & 21.1 & 20.5 \\
\hline $55-64$ & 9.5 & 12.1 & 12.7 & 12.7 & 12.3 & 12.4 \\
\hline $65-74$ & 4.7 & 5.3 & 7.2 & 7.8 & 7.9 & 7.7 \\
\hline $75+$ & 4.1 & 4.6 & 5.5 & 7.6 & 9.2 & 10.0 \\
\hline TOTAL & 100.0 & 100.0 & 100.0 & 100.0 & 100.0 & 100.0 \\
\hline \multicolumn{7}{|l|}{$\begin{array}{l}\text { Ratio of income share to } \\
\text { population share }\end{array}$} \\
\hline $15-19$ & 0.12 & 0.12 & 0.12 & 0.13 & 0.13 & 0.13 \\
\hline $20-24$ & 0.92 & 0.94 & 0.96 & 0.99 & 1.00 & 1.00 \\
\hline $25-34$ & 1.31 & 1.34 & 1.37 & 1.40 & 1.42 & 1.42 \\
\hline $35-44$ & 1.32 & 1.35 & 1.38 & 1.41 & 1.43 & 1.44 \\
\hline $45-54$ & 1.31 & 1.33 & 1.37 & 1.40 & 1.42 & 1.42 \\
\hline $55-64$ & 0.81 & 0.82 & 0.84 & 0.86 & 0.87 & 0.88 \\
\hline $65-74$ & 0.55 & 0.56 & 0.58 & 0.59 & 0.60 & 0.60 \\
\hline $75+$ & 0.58 & 0.59 & 0.60 & 0.62 & 0.62 & 0.63 \\
\hline TOTAL & $\ldots$ & $\ldots$ & $\ldots$ & $\ldots$ & $\ldots$ & $\ldots$ \\
\hline
\end{tabular}


An appreciation of this 'median individual effect' can be gained by examining the relative contribution to projected aggregate weekly income made by each age group. Table 2 gives each age group's projected percentage share of the working age population, their share of projected aggregate weekly income, and the ratio of these two indicators, which is the income contribution per person. The data show that 35-44 year olds in 2001 accounted for 19.1 per cent of the working age population, but contributed 25.3 per cent of aggregate weekly income, an income/population share ratio of 1.3. The underlying proportions at this age decline across the projection period, to 14.5 per cent, but their income to population ratio increases slightly, to 1.4 by 2051. In comparison, in 2001 and 2051 the age groups 15-19 and 20-24 years together account for 17.6 and 13.7 per cent respectively of the working age population, but only 9.2 and 8.0 per cent of aggregate income.

Sometime between 2041 and 2051, the median individual will move out of the high-earning 35-44 age group, and into the relatively high earning 45-54 age group. As a result, all else remaining equal, he or she and his or her proximate cohorts will continue to deliver a sizeable component of Australia's aggregate income well into the future. It is also likely that both the per capita and aggregate earnings of this age group will increase in time, as the baby boomers leave the labour market and their successors are encouraged to increase their labour force participation rates.

The passage of the median individual through the key income-earning age groups is one likely reason for the Guest and McDonald (2001 b, c) finding that population ageing will not greatly impinge upon Australia's future living standards. In short, this passage sustains the period of demographic gift, and, as Guest and McDonald argue, at least at national level, implies that government intervention is not in any way urgent in the short term.

\section{The Median Individual and Demographic Gift by State and Territory}

Again the analysis can be carried out at state/territory level. The results of this regional analysis appear in Table 3, which shows the year in which the median individual of each region entered or will enter the 35-44 year age group, the projected year in which he/she will leave and the resulting number of years of more narrowly concentrated demographic gift that each region can anticipate. Here we utilise two sets of ABS population projections to illustrate the likely parameters of change, the 'medium' variant (Series II) assuming lower net migration and fertility than previously noted for the 'high' variant (see ABS, 2000).

Two important findings emerge from this analysis. First, the median individuals of the Australian Capital Territory (ACT) and the Northern Territory are currently aged 33 and 30 years respectively, and have not yet even entered the all important 35-44 year age group, meaning that these regions have yet to look forward to the full benefits of their demographic gift. Indeed, the Northern Territory's median individual is not projected to enter this age group during the 
projection period - that is, before 2051 - under either projection series. Second, due to marked differences in the speed of population ageing and the impact of migration in each state and territory, there are equally marked differences in the number of years that each region will enjoy their gift. For example, under Series I (the high variant), both Tasmania and South Australia will enjoy 32 years of gift, while Victoria will reap the benefits for around 51 years. Under Series II (the medium case), Tasmania will enjoy only 24 years of gift, compared with 36 years for Victoria, 42 years for New South Wales and 47 for Queensland. The median individuals of New South Wales and Queensland (currently 36 and 35 years respectively) will not exit the 35-44 year age group during the entire projection period under the Series I assumptions, so it is not yet possible to ascertain their period of gift should these conditions prevail, while the median individuals of Western Australia, the ACT and the Northern Territory will not exit this age group during the entire projection period under either projection series.

Table 3: Actual and Projected Year in which Median Individual Will Enter and Leave 35-44 Year Age Group, by ABS Projection Series and State/Territory

\begin{tabular}{l|c|cc|cc|cc}
\hline & Median & \multicolumn{2}{|c|}{ Enter } & \multicolumn{2}{c|}{ Exit } & \multicolumn{2}{c}{ Period of 'gift' } \\
State & age 2002 & Series 1 & Series II & Series 1 & Series II & Series 1 & Series II \\
\hline SA & 37.9 & 1995 & 1995 & 2027 & 2025 & 32 & 30 \\
TAS & 37.7 & 1997 & 1997 & 2029 & 2021 & 32 & 24 \\
NSW & 36.1 & 1998 & 1998 & $2051+$ & 2040 & $\ldots$ & 42 \\
VIC & 36.0 & 1999 & 1999 & 2050 & 2035 & 51 & 36 \\
QLD & 35.3 & 2001 & 2001 & $2051+$ & 2048 & $\ldots$ & 47 \\
WA & 35.2 & 2002 & 2002 & $2051+$ & $2051+$ & $\ldots$ & $\ldots$ \\
ACT & 33.5 & 2010 & 2007 & $2051+$ & $2051+$ & $\ldots$ & $\ldots$ \\
NT & 29.9 & $2051+$ & $2051+$ & $2051+$ & $2051+$ & $\ldots$ & $\ldots$ \\
\hline TOTAL & 35.9 & 2000 & 2000 & $2051+$ & 2041 & $\ldots$ & 41 \\
\hline
\end{tabular}

Note: Shaded cells denote that entry and/or exit will not occur before 2051

Source: ABS (2000) Population Projections 1999-2100, Catalogue 3222.0

Finally, but to complicate matters slightly, the few exceptions to the rule that the 35-44 year age group is the highest earning age group need to be considered. These exceptions occur in the ACT and the Northern Territory, where the highest earning age group in each is currently that aged 45-54 years. The explanation for this disparity would seem to lie in the relatively large proportions of the economically active populations of these two regions employed in the relatively high-earning Government Administration and Defence industry, 23.9 per cent in the ACT and 17.7 per cent in the Northern Territory (ABS, 2003, Table 26b). By contrast, in 2001 the remaining six states had an average of 4.3 per cent of employed persons working in this key industry, ranging from 3.0 per cent in Victoria to 5.3 per cent in Tasmania. Relative proportions in each labour force 
status would of course also have a bearing on these statistics, as would the ratio of males to females at each age and in each industry and labour force status.

In the ACT and Northern Territory we also find that the 45-54 year age groups enjoy, respectively, the highest and second-highest per capita income of any age groups in any state/territory. Thus, not only have the median individuals of these two regions not yet entered their relatively high earning 35-44 year age groups, but they will not enter their very high earning 45-54 year age groups until sometime after 2051. Their demographic gifts will therefore be considerably greater than those of other states, and their respective periods of demographic gift will extend well beyond those implied in Table 3.

This does not mean that the projected aggregate earnings of the ACT and Northern Territory will necessarily follow the same trajectory. Instead, as indicated in Table 3, these are affected by the relative speed at which each region is ageing structurally (Jackson and Felmingham, 2002:102; see also Eding, 1999, and van der Gaag, 1999, using EU data), and thus by the relative size of their working age populations, vis-à-vis those of non-working age. Once the ACT passes the point at which it officially becomes an 'old' population (10 per cent over the age of 65 years - see Weeks, 1999:278-9), around 2007, it will undergo the most rapid ageing of any Australian State or Territory, taking just 25 years to transit the space between having 10 and 20 per cent aged 65+ years. This compares with 42 years for the country as a whole, ranging from 36 years in Tasmania and Western Australia to 44 years in New South Wales (Jackson and Felmingham, 2002:100-103). By contrast, the speed at which the Northern Territory will age is difficult to predict, since it is not projected to even reach the official 'old' population indicator of 10 per cent aged 65+ years until around 2047. The overall outcome for the ACT is that the data given in Table 2 would have shown much greater impact of population ageing were it not for the sustained presence of the median individual in the highest income-earning age groups.

\section{Summary and Discussion of Policy Issues}

This paper outlines Australia's experience of the demographic gift - the period during which the population age structure is optimal for the support of its younger and older members. The concept is applied to aggregate earnings for the period 1976-2001, and to projected aggregate earnings (2001-2051) to show first the economic impact of the gift as it has been enjoyed in Australia, and secondly an indication of its forthcoming loss, the legacy of population ageing. We show that over the 1976-2001 period, changes in age structure made a small but significant contribution to aggregate earnings, the percentage effect peaking around 1996. In 1996 this effect was worth approximately 7.8 billion dollars, and in 2001, although having fallen to 2.5 per cent of aggregate earnings, 8.2 billion dollars. Our projections to 2051 indicate that, ceteris paribus, population ageing will reduce aggregate earnings (over what they would be if it were possible for the age structure to remain constant) by around 1.9 per cent by 2011, increasing to 8.6 per cent by 2051. However, we argue that this impact will be ameliorated by the 
relatively slow movement of the median individual through the highest incomeearning age group, concentrating this aspect of the gift, and that the finding goes some distance to explaining those of other analysts, such as Guest and McDonald (2001b, 2001c), who argue that population ageing will have a minimal impact on other projected economic factors, such as aggregate savings.

The 'median individual' is the key player in this story. The significance of the median individual is that aggregate income will be at its maximum when he or she is in the highest income earning age group, and will decline as he/she moves through the age distribution to lower income earning groups. We show here that he or she and his/her proximate cohorts have in fact only just entered Australia's highest income-earning age group - that at 35-44 years - and will not exit this group until 2041 on the ABS medium case projections, and 2051 under the high variant. As a result, while the proportion of the total population that is at this age will decline over the 2001-2051 period, its contribution to aggregate income will increase. This effect will be sustained - albeit at a reducing rate - as the median individual moves into the next but typically lower-earning income-earning group, at age $45-54$ years.

However we also show that the situation differs markedly at the state and territory level, as these regions are undergoing markedly different rates of population ageing. Not only will the impact of population ageing on the aggregate incomes of each state/territory differ, but the median individuals of some states have not yet even entered the high-earning 35-44 year age group. The implications of these regional disparities are far-reaching, not least for the basis upon which fiscal transfers via the Commonwealth Grants Commission and States Grants Commissions are determined - highly complex issues that we have not been able to discuss in any detail here. But one very significant implication should at least be acknowledged; this is the argument that population growth influences economic growth only when it is associated with changes in the age distribution of the population; that it is the growth rate of the economically active population that is most positively correlated with economic growth, while population growth per se can actually have a negative effect (Bloom and Canning, 2003:6). As the compositional changes outlined above unfold across Australia's states and territories over a period of several decades, and usher in the related emergence of zero population growth and/or decline, it will be necessary to revisit many of the principles on which current grant allocation policies - which reward population growth - are based (see for example United Nations, 2000:4). We could argue, for example, that it is not the forthcoming regionally- and temporallydifferentiated shift to zero growth and/or decline of the working age population that is problematic, but rather, that current grant allocation polices are out of synchrony with this rapidly unfolding dynamic (Jackson forthcoming).

Indeed, overall, this study supports the general assessment made by Guest and McDonald in relation to living standards and population ageing, that no case for immediate large-scale policy intervention is needed. However, the quite disparate nature of the size of the demographic gift and its projected duration among the Australian states and territories is a different matter. Clearly, this 
disparity suggests that local as well as regional and national policy intervention is required. States Grants Commissions, for example, establish the basis of their 'disability factors' (population and other social, economic and geographical characteristics via which Local Governments are assisted to provide services) several years in advance. Institutional inertia means that these criteria cannot be changed readily, and raises the usual vexed question about policy coordination among the tiers of Australian government. In particular we note that the grant allocation process is a zero sum game played out between the states and territories. It is advantageous to move to a coordinated approach sooner rather than later, before these inter- and intra-regional tensions and issues emerge.

Also among these issues is likely to be the extent to which regionallydiffering rates of decline in the ratio of labour market entrants to exits may see a significant improvement in the employment and earnings circumstances of younger people, especially in the older regions. As population ageing unfolds there is likely to be an increase in competition within the labour market, and between the labour market and the tertiary education sector, for the participation of the same young people. Such demand could see the currently highest income earning age group pass downwards to a younger group, altering the distribution of income that our analysis has been based on, and, in particular, manifesting at different rates in the states and territories. It is critically important that such potential feedback mechanisms become a central consideration of social and economic policy making. Any increase in competition for the labour of the young would involve substantial adjustment costs in the labour market that would vary across the individual states and territories.

Mason (2003) argues that the manner in which the East Asian countries accomplished turning their demographic gift into economic advantage is important because of its potential value to other developing countries confronting similar changes. Central to the outcome was the attention given to absorbing the rapidly growing working age populations of these countries, over the 1960-1990 period. Policies included 'outward-looking strategies that encouraged domestic enterprises to compete in the global market place; stable macroeconomic policies that ensured low rates of inflation, discouraged capital flight and promoted economic efficiency; and the use of financial incentives, subsidies and access to credit to promote the growth of key [manufacturing] industries' (Mason, 2003:10). The main message of Mason's paper (and that of Bloom and Canning, 2003), is that failure to create an appropriate policy environment via which to capitalise on the demographic gift, risks a squandering of that gift. The message should not be lost on the policy makers of developed countries, many of which did squander at least part of their demographic gift, by permitting high levels of structural unemployment as the gift years peaked. As population ageing and the loss of the gift unfolds it is critical that both the challenges and opportunities presented by these demographic forces become more fully appreciated. 


\section{References}

Argy, F. (2001), 'Economic Rationalism in Australia - Survey of Members of the Economic Society of Australia ACT Branch’, Economic Papers 20(1):1-14.

Australian Bureau of Statistics (2000), Population Projections 1999-2100, Catalogue No. 3222.0.

Australian Bureau of Statistics (2003), Basic Community Profiles, Catalogue No. 2001.0.

Australian Bureau of Statistics (2003), Experimental Composite Leading Indicator Time Series Data, Catalogue No. 1350.0.65.001.

Australian Bureau of Statistics (various years), Births, Catalogue No. 3301.0.

Birdsall, N., A. Kelley and S. Sinding (2001), Population Matters: Demographic Change, Economic Growth, and Poverty in the Developing World, Oxford University Press, Oxford.

Bloom, D. and D. Canning (2003), 'From Demographic Lift to Economic Lift-off: the Case of Egypt', Applied Population and Policy 1:15-24.

Eding, H. (1999), 'Regional Population Ageing of the EU at Different Speeds up to 2015', Statistics in Focus, Theme 1, No. 4, Eurostat, Netherlands Interdisciplinary Demographic Institute.

Fitzgerald, V. (1993), National Saving: A Report to the Treasurer, AGPS, Canberra.

Guest, R. and I. McDonald (1998), 'The Socially Optimal Level of Saving in Australia 1960-61 to 1994-5’, Australian Economic Papers 37(3):211-229.

Guest, R. and I. McDonald (2001a), 'National Saving and Population Ageing', Agenda 8(3):235-246.

Guest, R. and I. McDonald (2001b), 'Would a Decrease in Fertility be a Threat to Living Standards in Australia?’, Australian Economic Review 35(1):29-34.

Guest, R. and I. McDonald (2001c), ‘Ageing, Optimal National Saving and Future Living Standards in Australia’, Economic Record 77(257) June:117-134.

Jackson, N. (forthcoming), 'Regional Population Ageing and Local Government Funding. A Tentative Consideration of the Issues', Australasian Journal of Regional Studies.

Jackson, N. and B. Felmingham (2002), 'As the Population Clock Winds Down: Indicative effects on Australia's States and Territories', Journal of Population Research, 19(2):97-117.

Kippen, R. and P. McDonald. (2000), 'Australia's Population in 2000: The Way We Were, and the Ways We Might Have Been’, People and Place 8(3):10-17.

Mason, A. (2003), 'Population Change and Economic Development: What Have We Learned from the East Asia Experience?’, Applied Population and Policy 1:3-14. 
Pollard, A., F. Yusuf. and G. Pollard (1974), Demographic Techniques, Pergamon Press, Rushcutters Bay, NSW.

United Nations (2000), Replacement Migration, Population Division, Department of Economic and Social Affairs, United Nations Secretariat.

Van der Gaag, N. (1999), 'Recent Population Decline in the EU: Recent Trends and Future Perspectives', Statistics in Focus, Theme 1, No. 3, Eurostat, Netherlands Interdisciplinary Demographic Institute.

Weeks, J. (1999), Population: An Introduction to Concepts and Issues, Seventh Edition, Wadsworth, Belmont CA.

Wood, A. (2001), 'Raising Levy isn't a Super Idea in Election Year', The Australian, April 10.

This research was funded by an ARC-Linkage grant. The authors would like to thank the anonymous referees and the editor for their insightful comments on this paper. We also thank our research assistants. We remain responsible for any errors or omissions. 



\title{
Australia's Strategic Environment: The Problem of Papua
}

\author{
Richard Chauvel
}

A proposal from Indonesia's House of Representatives to the government, in January 2004, that an integrated operation be conducted in Papua and a state of civil emergency declared, suggests a growing determination in Jakarta for Indonesia to impose its will on Papua, rather than resolve the issues of governance in the province. The proposal follows the appointment of InspectorGeneral Timbul Silaen, the head of police in East Timor in 1999, as the commander in Papua. Together with reports that one of the East Timorese militia leaders, Eurico Guterres, had established a pro-Indonesia militia in Papua, this raises the prospect that the Indonesian government is intending to implement in Papua in 2004 policies that provoked international intervention in East Timor in 1999. (The name of the western half of New Guinea has been a matter of political controversy since the 1940s. This article uses the names Papua, West Papua, Netherlands New Guinea, West Irian and Irian Jaya as appropriate to the context).

Papua and East Timor have different colonial pasts. The history of how they became part of Indonesia also diverges significantly. However, both territories have been the focus of differences between Indonesia and Australia that have coloured nearly all aspects of bilateral relations for protracted periods of time. Both Papua and East Timor touch on issues of great sensitivity for Indonesia and Australia. First and foremost among these are Indonesian sovereignty and national unity in regions on the Christian and Melanesian periphery of Indonesia's religious and ethnic mosaic. One of the legacies of the Pacific War was an Australian interest in the security, stability and governance of the eastern-most regions of the archipelago nearest to its own territory. In the post-Cold War era, governance has come to subsume issues such as human rights, indigenous rights and the right of self-determination.

This article will examine how Australia, in the course of the dispute of the sovereignty of West New Guinea, came to accept Indonesia on Indonesian terms - its territory, its multi-ethnic, multi-faith character and its underlying rationale as a nation state. In 1962, Australia accepted, however grudgingly, the incorporation of Papua into Indonesia. Australia came to appreciate the crucial strategic interest it had in developing close and cooperative relations with Indonesia. The second part of the article discusses the growth Papuan identity under Indonesian rule as well as the development of Indonesia's policies as the government faced the Papuan challenge to its sovereignty, following the resignation of President Soeharto. The third part of the article looks at Australia's policy options as Indonesia adopts strategies to repress the Papuan independence

Richard Chauvel is Director of the Australia Asia Pacific Institute at Victoria University, Melbourne. 
movement that rely increasingly on the use of force. If the dispute over West New Guinea was the means through which Australia came to terms with Indonesia, then devising the appropriate policy towards Indonesian governance in Papua shows how difficult it is to live with Indonesia.

\section{West New Guinea: 12 Long Years of Discord}

West New Guinea was the focus of the first major dispute between Australia and Indonesia. In 1950 the Menzies government asserted that Australia had a vital strategic interest in the future administration of West New Guinea. In the view of Percy Spender, the then Minister of External Affairs, the territory did not form part of Indonesia, but rather had more in common with the then Australian territories of New Guinea and Papua. Spender recognised that Australia also had a vital interest in the political and economic stability of Indonesia. The inclusion of West New Guinea in Indonesia would not add to regional stability, but rather form a weakness in Southeast Asian strategic planning. Australia wanted The Netherlands to retain its sovereignty in the territory and offered economic, administrative and defence assistance so that The Netherlands would not give in to Indonesia's demands.

Spender had established a policy that would see Australia in conflict with Indonesia over the status of a territory that Indonesia claimed as part of its national territory since the 1945 proclamation of independence. The West New Guinea dispute would colour nearly every aspect of Australia's relations with Indonesia for twelve years. In Indonesian eyes, the February 1950 Cabinet decision transformed Australia from being its closest western supporter during the struggle for independence to its most clearly identified opponent, along with the Dutch. Australia's strategic assessment of West New Guinea's importance was much influenced by the then still fresh memories of the campaign against Japanese forces in New Guinea. There was a strong desire to see that the territory did not come under the administration of an Asian power that would have a land border with Australian administered territories. The policy of supporting continued Dutch administration was not motivated by any especially warm feelings towards the Dutch nor out of any concern for what might be construed as Papuan interests. The objective was to keep Indonesia out.

As Indonesia became entangled in the Cold War during the mid and late 1950s, the tensions between the competing objectives of Australian policy became more acute. In 1958 Spender's successor, Richard Casey, saw the policy predicament with great clarity, but had no sense of a way out. How could Australia keep the Dutch in New Guinea, not make an enemy of Indonesia, and at the same time support the American objective of arming the Indonesian military to enable it to control the Communists?

In January 1959 the Menzies Cabinet recognised for the first time that the strategic importance of Indonesia to the US and Australia was greater than that of West New Guinea, and therefore it should be a major objective of Australian policy to keep Indonesia non-communist and friendly. Though recognising the 
greater significance of Indonesia, the Menzies government persisted in supporting continued Dutch sovereignty. It would be a further three years before the next External Affairs Minister, Garfield Barwick, recognised that the policy objectives Australia had pursued since 1950 were antithetical.

Following a 1957 Joint Statement with The Netherlands, Australia publicly supported the objective of self-determination for West New Guinea. The Statement foreshadowed the possibility that the Dutch and Australian halves of the island might form a greater Melanesian state upon independence. The Netherlands program for rapid political advancement and decolonization as an independent Papua by 1970, launched in 1960, had an actuality that unnerved Australian policy makers, particularly after the first stirrings of nationalist sentiment in West New Guinea. This came in the form of a Papuan assertion of the right to become an independent nation and the raising of the Papuan national flag on 1 December 1961, which provoked President Sukarno to issue his 'Trikora' commands.

The first of these was to destroy the Dutch-created puppet state of West Papua. In January 1962, Garfield Barwick saw the prospect that the Dutch might implement their program of decolonisation of West Papua as an undesirable outcome. He argued that ' ...the early emergence of an independent state of West New Guinea, unquestionably not economically viable, and certainly not militarily self defensible, so far from solving the problem, must be a standing provocation to Indonesian activity, probably of an aggressive military kind'. In the context of the Cold War, Barwick argued, the friendship of the Indonesian people would constitute a '...greater bulwark against the southward march of Communism...' than a Papuan state (Barwick 1962). Australia's commitment to selfdetermination in Papua, already undermined in 1959, vanished with the 1962 decision to support resolution of the dispute in Indonesia's favour.

Barwick understood that successful negotiations would probably include a 'face saving' formula for the protection of Papuan interests. The Papuans' right to choose their own future would be 'entirely dependent on Indonesian good faith', although there would be no way of ensuring that this aspect of the agreement would be carried out. The Australian government supported the later decision of Soeharto's New Order government to fulfil its international obligations under the 1962 New York Agreement by holding an act of self-determination in West Irian. The manner in which Indonesia conducted the 'Act of Free Choice' in 1969 caused the government embarrassment, but the outcome - confirming West Irian's status as a province of Indonesia - was the only one contemplated by Australia.

\section{Indonesian New Guinea}

Part of what Australia had come to accept about Indonesia in 1962 was the nationalists' assertion that West New Guinea had been an integral part of Indonesia since the proclamation of independence in 1945. Barwick had recognised that there was '...a real deep-seated and not illogical national 
sentiment for the attainment of sovereignty over the Territory...[among]...a substantial, responsible and wide-spread Indonesian opinion' (Barwick 1962). Contrary to the arguments that The Netherlands and Australia advanced during the dispute, West New Guinea's inclusion was important precisely because its inhabitants were ethnically different from many other Indonesians. It showed that Indonesia was born of a common political struggle, rather than a nation that rested on a shared ethnic and cultural heritage.

The nationalists' assertion that West Irian is an integral part of Indonesia is the golden thread that runs through successive Indonesian governments' policies, first against the Dutch challenge to its sovereignty and, since 1961, against the Papuan national challenge. In 1962 Australia made a strategic choice that its national interest lay in developing a friendly and cooperative relationship with a strong and united Indonesia. Barwick's concerns about the emergence of an unviable and defenceless independent Papua were reflected a decade later in the decisions of the Whitlam and Fraser governments with respect to East Timor.

The first sign of nationalist activities in Papua was one of the factors that prompted Sukarno to raise the stakes in the struggle with the Dutch by threatening military action. Sukarno understood that a rival Papuan national claim to West New Guinea posed a far greater threat to Indonesia's own claim than the continuation of Dutch colonial rule. Nevertheless, when Indonesia assumed administrative authority, officials found that the Papuan political leaders were less sophisticated, less established in their nationalist objectives and less well organised than the Indonesians had feared. In the first couple of months most of the Papuan leaders were persuaded, by one means or another, to cooperate with the Indonesian administration. Australian observers were not much impressed with the first generation of Papuan nationalists. The Australian Liaison Officer with the United Nations Temporary Executive Authority admired the skill with which his Indonesian colleagues worked with the Papuan leaders. He observed amity and full acceptance between the two groups: 'There is certainly no evidence of New Guinea “Nationalism””.

Even today it is not uncommon for influential Indonesians to blame the Dutch for Indonesia's problems in Papua. It is asserted that the Dutch deliberately cultivated false aspirations, including that of an independent Papuan state. Yet in 1962 the ideal of independent Papua was limited to the several thousands of Dutch educated Papuans scattered around the small urban centres of Netherlands New Guinea. They were officials, police, soldiers, paramedics, teachers and workers in the Sorong oil industry. The elite found the prospect of an independent Papua separate from Indonesia an attractive proposition. However, the idea of Papua, let alone an independent nation state of West Papua, had limited currency outside these circles.

The Papuan nationalists of the post Soeharto era have looked back to 1961 for inspiration and political symbols. They have adopted the Morning Star Flag and the other national symbols chosen then. The 1961 flag raising ceremony was reinterpreted as a declaration of independence. However, what the nationalists, organised in the Presidium Dewan Papua, achieved in 1999-2000 during the 
'Papuan Spring' - the establishment of a territory-wide organisation, and the mobilisation of widespread support for the straightforward demand for Papuan independence through peaceful dialogue - was far beyond anything that the leaders of the earlier generation could have imagined.

After the Presidium's Papuan Congress of mid 2000, an Indonesian intelligence report observed that the atmosphere down to the village level was one of euphoria and enthusiasm with the idea of Merdeka (independence). Those supporting Merdeka were increasingly cohesive and were endeavouring to 'socialise' the results of the Congress throughout Irian Jaya, elsewhere in Indonesia and internationally. Without wanting to diminish the achievements of the Papuan leaders, they were greatly assisted in the consolidation and dissemination of a Papuan identity by the policies and practices of the Sukarno and Soeharto governments. Ironically and sadly, the rhetoric of Indonesia's own nationalists seems an appropriate description of development of a pan-Papuan identity. Papuan identity flourished and spread, not out of a shared ethnic, religious or cultural heritage, but as a common struggle against Indonesian rule.

Indonesians rightly considered the negotiated settlement with the Dutch in the 1962 New York Agreement as a great nationalist victory. Indonesia had liberated the Irianese from the yoke of Dutch colonialism. In Papuan experience this transition might have seemed different - more like swapping a paternalistic, mostly benign and materially generous colonial regime with a repressive, corrupt and military dominated one that could not make up its mind whether its mission in West Irian was to civilise the indigenous inhabitants or treat them as fellow citizens.

The sporadic and localised Papuan resistance to Indonesian rule that came to be known under the umbrella label of the Organisasi Papua Merdeka (OPM, Organisation for Papuan Independence) challenged and embarrassed the military but, ultimately, has never threatened Indonesian control of the province. The legacy of the OPM is important in two respects. First, however ineffective it might have been as a military organisation, the OPM served to keep the ideal of Papuan independence alive. Few Papuans made the decision to go bush and join the OPM, but many more identified with the OPM. Second, and not unrelated, was the response that the OPM drew from the security forces. The 'security approach' that characterised the Soeharto government's response to armed resistance in Irian Jaya, as elsewhere in Indonesia, brought with it the seemingly inevitable widespread and frequent human rights abuses. The result was that the security approach itself became one of the factors fuelling anti-Indonesian sentiment. The massive influx of transmigrants was another aspect of Indonesian rule that gave Papuans a sense that they were being dispossessed of their own homeland. Indonesia has been able to maintain its authority in Papua, but has done so largely without the consent of the Papuan population. Not many Papuans have been convinced that their preferred political future should be as part of Indonesia. 


\section{Could Reformasi be Tolerated in Papua?}

Nearly three decades after Indonesians thought they had liberated the Papuans, they were confronted with a strong resurgence and transformation of the Papuan nationalist movement. The Papuan renaissance followed Soeharto's forced resignation in May 1998, and its success was a measure of the failure of Soeharto's policies. It coincided with the struggle of many Indonesians to create a more open, plural and competitive political system. President Habibie received a delegation of 100 Papuan leaders in February 1999, shortly after he had announced that the East Timorese would be given the choice of autonomy within Indonesia or independence. The Papuans' demand was straightforward. They demanded independence and wanted to achieve it through peaceful dialogue with the Indonesian government.

Habibie was taken aback by the demand for independence; he gave no formal response at the meeting. Indonesian governments were accustomed to separatist demands for independence, but less so to groups that expected to achieve their objectives through peaceful negotiations. The Papuan campaign was awkward because it coincided with Indonesia's own process of democratisation. Habibie and his successors have been confronted with the dilemma of how much freedom of expression and organization could be tolerated in Papua when those freedoms were used to advocate and successfully mobilize widespread support for Papua's independence.

Habibie's successor, Abdurrahman Wahid, Indonesia's first democratically elected President, sought to resolve the dilemma by attempting to accommodate Papuan aspirations within Indonesia. He changed the name of the province from Irian Jaya to Papua and permitted the Morning Star flag to be flown. However, Wahid made it clear that it was his duty as President to defend the territorial integrity of Indonesia. Following his visit to Papua to celebrate the New Year in 2000, Wahid maintained an intermittent dialogue with the Papuan leaders. He contributed to funding the Presidium's Papuan Congress. The Presidium considered that it had received a popular mandate from the Congress to advance the struggle for independence.

The Congress was also the turning point of Indonesian policy towards the Papuan independence movement. Wahid's accommodation of Papuan aspirations was the focus of criticism at the Annual Session of the People's Consultative Assembly (MPR) in August 2000. The president's agreement to change the province's name to Papua and his granting of permission to fly the Morning Star flag were rejected. He was given the task of taking decisive action against separatism and implementing special autonomy for Papua and Aceh.

The MPR session was indicative of the limits of the political elite's tolerance of Wahid's attempts to accommodate Papuan aspirations. Within the security and intelligence organisations, his policies had caused considerable disquiet. One Jayapura police report argued the president's financial contribution to the holding of the Congress provided the Presidium with a very broad opportunity to organize 
and use the president's support to its advantage. The president's permission to fly the Morning Star flag complicated the position of the security forces in the field. The separatist groups used the issues of democratisation and human rights to weaken the morale of government officials. The government gave the separatist groups the opportunity to 'socialize' the results of the Congress. A memorandum to the Minister of Internal Affairs argued that it was necessary to take immediate, concrete and appropriate actions to anticipate further expansion of the '... euphoria and enthusiasm for the idea of Merdeka (independence)...' that the Congress had stimulated. It envisaged graduated activities, both overt and clandestine, targeting a broad spectrum of Papuan leaders. It argued that the implementation of both regional autonomy and partition of the province should be accelerated.

Government approaches to the dilemma posed by the Papuan demands for independence was reflected in vacillations in policy from the repressive to the accommodative. The vacillations are also indicative of the significant differences in approach within both Wahid's and Megawati Soekarnoputri's governments. In the months after the 2000 Annual Session of the MPR both approaches were evidenced. The government's determination to remove the symbols of Papuan nationalism from public display, the arrest and trial of five leaders of the Presidium for treason, the murder of Theys Eluay - the Presidium's figurehead and one of the five on trial, by Kopassus (Special Forces) soldiers in November 2001 - and the indiscriminate reprisals in response to Papuan attacks on the security forces, were examples of the former.

With these measures the government reasserted its authority in Papua and closed down the political space in which the independence movement had flourished. However, the 'Papuan Spring' revealed something of the fragility of Indonesian authority and the lack of Papuan consent for Indonesian rule. The imposition of Jakarta's authority has come with a heavy reliance on force and state violence. The experience of the New Order would suggest that this might ultimately be counter-productive. Repression risks fueling the resentment it is supposed to quell.

Although the implementation of special autonomy was part of the MPR's instruction to Wahid to deal with the separatist challenge in Papua, the way in which the special autonomy law was formulated accommodated many Papuan interests and aspirations as these had been articulated at the Presidium's Papuan Congress. Wahid's acknowledgement of the name Papua and the Morning Star flag was much admired by Papuans, but perhaps his greatest gift to Papuan interests was the policy vacuum surrounding special autonomy. Special autonomy for Papua had been part of the Broad Outlines of Government Policy (GBHN), 1999-2004. The MPR had instructed Wahid to implement it, but his administration had done little to give substance to the policy. The policy vacuum was filled by the provincial government of Papua and the special autonomy team of academics, officials, NGO leaders and intellectuals appointed by the governor. The special autonomy law of September 2001 (Law 21/2001) was based on proposals submitted by the governor of Papua and negotiated between a special 
committee of the House of Representatives (DPR) and the governor's special autonomy team. The DPR's passing of the legislation did not imply its acceptance within the government.

The Law established Papua as a region of self-government within Indonesia. It provided for a substantial devolution of decision-making authority and distribution of financial resources from the centre to the province. With the establishment of an ethnic Papuan upper house (MRP), it sought to promote and protect Papuan interests. The province would be called Papua, and it would have its own flag, anthem and coat of arms, in addition to the Indonesian national ones.

\section{Megawati’s Old Order, 2001-04}

In her first Independence Day speech on 16 August 2001 President Megawati Soekarnoputri committed her government to special autonomy for Papua. However, it became evident that there were people within the government who had fundamental objections to key aspects of the law. They had not been involved in its formulation, but were in a position to undermine its implementation. For these people special autonomy was too great a concession. It gave strong expression to Papuan national aspirations and was an affront to many core Indonesian nationalist beliefs. If implemented, the law would empower and resource a Papuan elite in Jayapura—an elite whose loyalties were suspect.

Rather than a means to secure Papua within the national fold, special autonomy was thought of as a step towards Papuan independence. The governor of the National Resilience Institute (Lemhannas), Professor Dr Ermaya Suradinata, argued in January 2002 that the partition of Irian Jaya, was the best solution to the threat of national disintegration posed by special autonomy for the province of Papua. Among the objectives of partition was to isolate and marginalise the Papuan advocates of independence (disintegrasi) and undermine the symbolic nexus that the name Papua and the Morning Star flag had with Papuan nationalism. The three provinces would have different cultural identities. This line of thinking became government policy with Presidential Instruction 1/2003 to divide the province into three: West Irian Jaya, Central Irian Jaya and Irian Jaya. Reflecting Ermaya's reasoning, the three provinces would assume the government's preferred nomenclature 'Irian Jaya'.

What followed during 2003 was confusion and an apparent impasse in policy as the government struggled to explain how division of the province could be compatible with special autonomy, which officially the government still espoused, although it had not issued the necessary regulations to enable effective implementation. The provincial authorities in Papua had not been consulted about the division of the province, which seemed to run counter to both the spirit and the letter of the special autonomy law. Given the participation of the provincial government and much of the academic and intellectual elite in the formulation of the law, the lack of consultation was deeply resented in the province capital, Jayapura. The response from the established Papuan elite in Jayapura and Jakarta 
has been strong and quite uniform in its rejection of partition. For these people partition was an attack on special autonomy. Looked at from a longer historical perspective, the decision to divide the province seemed to have lost Jakarta the support of the one group of Papuans who, out of an assessment of their own interests, have supported an Indonesian policy relating to the governance of Papua.

Yet it was this group that Lemhannas and others within the government considered part of the problem. Their loyalty to the State was suspect, yet special autonomy empowered them with decision-making authority and resources. Outside the established elite and those out of power in Jayapura, the government found some Papuan supporters for partition. The social and political tensions in Papua generated by the government's decision to partition the province were most evident at the attempted inauguration of the province of Central Irian Jaya on 23 August 2003. The inauguration in Timika sparked several days of violence between pro- and anti-partition groups of Papuans and pro-partition immigrants, which resulted in the death of five people and injuries to dozens of others.

The government's initial responses to the violence were confused and confusing. Security Minister Susilo Bambang Yudhoyono papered over some of the cracks in the government's position when he announced that partition would be put on hold and the status quo would be maintained - meaning that the province of West Irian Jaya would remain, but Central Irian Jaya would not be established. Together with the DPR, the government would review the laws relating to Papua. At least in the Security Minister's statement, if not in those of his President and Ministerial colleagues, there was some recognition of the contradictions between special autonomy and division of the province. The political tensions and violence generated by the government's determination to divide Papua and undermine special autonomy, as well as the confusion within government policy, suggests that there is no easy return to the old ways of Indonesian governance in Papua.

If it is the case that special autonomy has been abandoned or significantly undermined, this raises the question of why it has been so difficult for governments to accommodate Papuan aspirations within the Indonesian state. This article has stressed the nationalist ideological obstacles to meaningful accommodation as well as the anxieties that special autonomy would empower a distrusted Papuan elite. To loosen controls risks opening up the political space for Papuan nationalist activities. Besides these factors, the political economy of the security forces in Irian Jaya and the symbiotic relationships the security forces have developed with resource companies - most notably the copper and gold mining giant, Freeport - have created an institutional imperative for the maintenance of the territory as a zone of conflict. The security forces have no interest in conflict getting out of control, but they have little interest in its resolution. Whether the core of the government's difficulties related to issues of nationalist ideology, the control of decision making and resources, or the institutional imperatives of the security forces, these factors are deep-rooted, systemic and not open to easy modification. 
The shift in government policy in Papua from an inclusive framework capable of resolving the issues of governance in Papua to re-imposing Jakarta's control through partition occurred in the context of a determination to defend Indonesia's unity and territorial integrity. This context is the breakdown of negotiations about Aceh and the subsequent military campaign against the armed independence movement. One of the consistent themes in Susilo Bambang Yudhoyono's speeches in mid 2003 has been that Indonesia's unity and territorial integrity is non-negotiable. Indonesia's national security priority is fighting armed separatism rather than terrorism. He recognised that the most serious military threat was in Aceh, whereas the challenge in Papua was political.

\section{Australia's Interests and Options}

Related to the preoccupation with unity and territorial integrity have been concerns about international-not least, Australian-interference in Irian Jaya. For example, at the time of the killing of one Indonesian and two American teachers near the Freeport mine on August 30 2002, Susilo Bambang Yudhoyono ordered the National Intelligence Agency to investigate a conference at Sydney University's Centre for Peace and Conflict Resolution. Eight Papuans attended the conference; Susilo Bambang Yudhoyono said the Papuan group left for Australia within hours of the killings at Freeport. The objective of the investigation was to 'prevent any assumption that Australia is involved in this case' (Garnaut, 2002).

When Australian Prime Minister, John Howard, visited Jakarta in February 2003, President Megawati and her ministers raised the issue of the support of some groups in Australia for Papuan independence and whether the Australian government funded aid organizations that supported independence. Marty Natalegawa, a spokesman for the Department of Foreign Affairs, told the press:

We know the Australian government's view in support of our territorial integrity. At the same time we will make known our concern not to allow certain groups under the guise of democracy, free speech and the like basically to try to disrupt and disturb our national unity, which we will defend, as would any other sovereign country. (Skehan, 2003).

The precedent established by international intervention in East Timor in 1999 is both the source of Indonesian anxieties and the reason for lack of credibility in Australian reassurances. Shortly after the loss of East Timor, former Foreign Minister, Ali Alatas, argued that the doctrine of 'humanitarian intervention' enables both external forces to exploit internal conflicts to their own political ends and elements within Indonesia to create crises to seek international attention and provoke interference. Presumably the fear is that excessive military action in Papua will enable NGOs and solidarity groups to mobilize domestic pressure on their governments to reconsider their recognition of Indonesian sovereignty in 
Papua. Indonesia's international position in relation to Papua has been difficult since the Presidential Instruction: special autonomy had been sold to friendly governments as the policy framework in which the Papua problem could be resolved within the framework of the Indonesian state. Friendly governments, including Australia, supported special autonomy, not least because it absolved them from having to make difficult decisions about Indonesian sovereignty.

Since the Presidential Instruction was issued, foreign support for special autonomy has been regarded with suspicion. From Jakarta's perspective, the protracted difficulties between Indonesia and the US about an appropriate investigation into responsibility for the killing of the three teachers near the Freeport mine have thrown an unwelcome spotlight onto governance in Papua. It is in this international context that the appointment of Timbul Silaen as the Police commander, together with reports of Eurico Guterres' militia activities, are important. They do not imply any significant change in policy, but are unhappy reminders in the eyes of the international community of what went wrong for Indonesia in East Timor in 1999.

The Timor precedent creates policy difficulties with respect to Papua for the Australian government. As Professor Andrew McIntyre has noted, Papua is a lose-lose proposition for Australian policy makers. In response to the Indonesian government's concerns about AusAID funding for NGOs that support Papuan independence, the Australian government has been fulsome with its frequent statements of support for Indonesia's sovereignty in Irian Jaya. However, as implied by Natalegawa's statement, cited above, the credibility of these statements in the eyes of the government in Jakarta are in inverse proportion to their frequency. The Timor precedent evokes the response that, while support for Indonesian sovereignty had been Australia's long-standing position, this support evaporated when it mattered most to Jakarta. Contrary to Australia's objectives in 1999 (as expressed in a letter from Howard to Habibie in December 1998 concerning the future of East Timor), the Howard government's later celebration of its successful role in East Timor has convinced many Indonesians that East Timorese independence was the desired outcome for Australia. This impression fuels suspicions about Australia's intentions in Papua.

In these circumstances, what are Australia's interests and how can they best be advanced? Garfield Barwick’s 1962 assessment that Australia's interest lay in close and cooperative relations with a strong and united Indonesia remains Australia's preferred strategic objective, intervention in East Timor notwithstanding - indeed, perhaps reinforced by the subsequent experience in Timor. Does Australia need another, not so small, Melanesian state to support? The fragmentation of Indonesia, a less likely prospect than it seemed immediately after the fall of Soeharto, would greatly complicate Australia's strategic environment. Even the separation of Aceh and Papua, particularly the latter, would have this effect. However, the short and long-term trends in Indonesian governance in Irian Jaya, if they were to continue, might make international support for Indonesian rule in Papua more difficult to sustain. 
Australia was not able to sustain its preferred strategic objective with respect to East Timor. The decision to intervene broke a psycho-strategic taboo. Indonesia's fragmentation was no longer unthinkable, nor was Australian intervention. With respect to Papua's neighbours, Australia has intervened to restore law and order in the Solomon islands, and provided a highly interventionist support program in PNG. In the context of Australia's support program in Papua New Guinea, Foreign Minister Alexander Downer stated that (Forbes, 2003):

We are not willing to stand back and watch regional neighbours descend into instability. Countries like PNG still lack the preventative and enforcement capabilities that they need to combat corruption.

On occasions Downer has expanded the rhetoric in more abstract terms: 'Sovereignty, in our view is not absolute. Acting for the benefit of humanity is more important.' (Burchill, 2003) Indonesia is not PNG or the Solomons. Australia has sufficient authority and influence in PNG and the Solomons for its intervention to be at the invitation of the respective governments. This is most unlikely to happen in Indonesia.

Australia's reengagement in PNG not only is an example of Australia's willingness to intervene in a neighbour's domestic affairs, but also heightens Australian interest in developments across the border in Papua. Political instability in Papua and refugee flows into PNG would complicate Australia's rehabilitation efforts in PNG, and Papuan use of sanctuary in PNG would be resented in Jakarta.

The lingering and deeply felt Indonesian resentment about Australia's role in the loss of East Timor, together with the history of the earlier dispute concerning West New Guinea, suggests that any real or imagined Australian involvement in Papua would have a profound and enduring impact on Australia's relations with the government of Indonesia. Papua is of much greater economic value to Indonesia than East Timor was and is an integral part of the Indonesian nationalist enterprise. An understanding of Indonesian sensitivities is the basis for much academic advice on Papua that Australia has little choice but to continue its formal support for Indonesian sovereignty. As Professor Jamie Mackie (2003) warned, if Australia were to say anything else, it would arouse a hornet's nest in Indonesia.

Such are Indonesian sensitivities created by the East Timor intervention that Sidney Jones, Indonesia Director of the International Crisis Group, advised that it would be most unwise for Australia to offer to mediate in Papua at the time of the Timika violence sparked by the attempted establishment of the new province of Central Irian Jaya (Jones 2003). Neither Mackie nor Jones is exaggerating Indonesian sensitivities. However, frequent Australian ritual protestations of support for Indonesia's sovereignty do little to convince the Indonesian government that Australia shares some of its strategic interests in Papua. A policy that amounts to little more than cross the fingers, hope for the best and look the other way makes no contribution to resolving the governance problem that poses a threat to Australia's strategic interests. The implied assumption underlying the 
policy is that while the situation in Papua might be bad, it has been so for most of the period of Indonesian rule and will not become much worse. The discussion of Indonesian policy developments in this article suggests that such an assumption is optimistic. The difficult judgement for Australian policy makers is how much worse would the situation have to become in Papua before the Australian position became untenable.

Australian diplomatic endeavours to assist the government in Jakarta to resolve some of its governance problems in Papua will evoke suspicion and resentment. However, the magnitude of Jakarta's displeasure at such endeavours will be minor compared with that which any more active Australian intervention would provoke, if the situation in Papua were to disintegrate further and continued Indonesian rule to become untenable.

This article has argued that the long-term pattern of political change in Papua and the short-term trend in policy are likely to make Jakarta's position in Papua increasingly difficult. Papuan identity is much more widespread, and the commitment to a Papuan nation much stronger, in 2004 than when the Dutch left. The educated elite in Papua is much more numerous, skilled and politically experienced than in 1962. The obstacles to more inclusive and accommodative Indonesian policies in Papua are deeply rooted and systemic. The government's current attempts to suppress the independence movement seem likely to generate political instability and social tensions, as well as further to consolidate Papuan support for independence. The challenge for Australian policy makers is to persuade their Indonesian counterparts that they share some strategic interests in Papua, and that these are best served by the establishment of a form of governance that accommodates Papuan interests and aspirations.

Many Papuans believe that their interests were sacrificed in the New York Agreement and by the UN's acceptance of the results of the 1969 Act of Free Choice. There has been little in Papuan experience since 1962 to convince them that their preferred political future should be as part of Indonesia. It is difficult to imagine that anything less than near total transformation of Indonesian governance will begin to persuade them otherwise.

\section{References}

Barwick, G. (1962), Memorandum by Minister for External Affairs on Cabinet Submission No. 10, 11 January, Prime Minister's file C508 pt 3, CRS A4940, Australian National Archives.

Burchill, S. (2003), 'What the West Wants from Indonesia’, Joyo Indonesia News, Z-Net, October.

Forbes, M. (2003), 'Troops for PNG Mission Ruled Out’, The Age, 15 October.

Garnaut, J. (2002), 'Outrage as Murders Linked to University’, Sydney Morning Herald, 13 September. 
Jones, S. (2003), 'Papua Province: Indonesia's Next Flashpoint?’, Interview on Asia Pacific/Radio Australia, 5 October.

Mackie, J. (2003), 'Relations with Australia Affected by Papua', Interview on Asia Pacific/Radio Australia, 9 May.

Skehan, C. (2003), 'A Papuan Free for All', Sydney Morning Herald, 11 March, http://www.smh.com.au/articles/2003/03/10/1047144926255.html.

The author is indebted for comments from two anonymous referees. 


\section{The Millennium Challenge Account: Transforming US Foreign Assistance Policy?}

\section{Steven Radelet}

$\mathrm{I}$ n March, 2002, US President George W. Bush proposed establishing a new 'Millennium Challenge Account' (MCA) that would provide substantial new bilateral US foreign assistance to a select group of low-income countries that are 'ruling justly, investing in their people, and encouraging economic freedom'. In principle, the MCA could bring about the most fundamental changes to US aid policies since the Kennedy administration. The MCA's significance lies partly in its scale, since the $\$ 5$ billion target annual budget proposed by Bush would represent a nearly 50 percent increase over current US aid. Even if the $\$ 5$ billion target is never fully reached - and it seems unlikely that it will, given current US budget realities - the MCA will lead to a significant increase in US aid in the near future. Perhaps even more importantly, however, the new program brings with it the opportunity to improve significantly how the US delivers its foreign aid.

Traditional foreign aid programs around the world have been criticised for a variety of reasons, including the following:

- Aid programs try to achieve conflicting goals, encompassing everything from supporting political allies, encouraging growth, improving health and education, strengthening the environment, responding to humanitarian emergencies, and distributing surplus agricultural production as food aid.

- Too much aid is directed at countries that either are not the poorest countries or that are political allies that do not have policies conducive to using aid effectively or enhancing development more broadly (Collier and Dollar, 2002).

- Donors do not sufficiently involve recipients in program design, and earmark significant funds for their own priorities, leading to a lack of local 'ownership' of, and commitment to, donor-financed programs.

- Aid programs are inefficient, with large bureaucracies imposing high administrative costs on recipients (Easterly, 2002). Donors also tie significant amounts of aid to purchases in their own country, which, by some estimates, reduces its value to recipients by 15-30 percent (Jempa, 1991).

- Donor activities are not well harmonised, with multiple donors financing similar projects with differing design, implementation, monitoring and evaluation systems, which leads to duplication, higher administrative costs for the recipients, and less effective aid flows. For example, in Tanzania in

Steve Radelet is a Senior Fellow at the Center for Global Development in Washington, DC, and was Deputy Assistant Secretary of the US Treasury for Africa, the Middle East, and Asia From January 2000 through June 2002. 
the early 1990s, donors were implementing 15 separate health projects at the same time (Van de Walle, 2001).

- Monitoring and evaluation systems are badly flawed. Donors rarely measure results accurately, so there is little systematic information about what works and what does not.

These criticisms have been levelled at foreign aid programs generally, as well as to specific donors such as the World Bank, the US Agency for International Development (USAID), and the Australian Agency for International Development (AusAID). For example, in a stinging attack Hughes (2003) contends that Australian aid has been highly ineffective in promoting development in the Pacific. She argues not only that aid to the Pacific has failed to spur development, but that it actually has had a negative effect on growth by distorting incentives for the private sector and by creating economic 'rents' that serve to enrich senior officials in the countries that receive aid. Although she does not offer proof of this negative relationship, she concludes that the best solution would be to halt all Australian aid to the Pacific. As a softer alternative, she recommends that AusAID insist on the principle of 'mutual obligation', in which aid funds are separated from recipient country budgets and expended only on evidence of met targets after careful monitoring and auditing of expenditures. Although Hughes' views are in the minority among Australian development specialists and have been hotly contested, they are indicative of some of the criticisms of foreign aid. AusAID's response has been to defend its record and to argue that aid has helped development outcomes in the Pacific to be better than they otherwise would have been (AusAID, 2003).

These debates about the effectiveness of foreign aid were central to the formulation of the MCA. The Bush administration sees the MCA as addressing some (although not all) of the criticisms, because it will differ from current programs in four critical ways. First, it will have narrower and more clearly defined objectives, aimed solely at supporting economic growth and development. Second, it will provide aid to only a select group of low-income countries that are implementing sound development policies. Third, the administration hopes to reduce bureaucratic costs by administering the program through a new, very lean, government corporation called the Millennium Challenge Corporation (MCC). Fourth, the administration plans to give recipient countries a greater say in program design, implementation and evaluation.

In many ways the MCA is a promising new program. However, much work is required before the promise turns into a reality, and it is quite possible that the program will never reach its potential. Many of the details on how the new program will operate remain uncertain. In January, 2004 - 22 months after Bush first proposed the program - Congress finally passed the Fiscal Year 2004 budget that provides the legal authority to initiate the program and $\$ 1$ billion for its first year of operation. The delays were due, in the first instance, to the administration being distracted throughout early 2003 by the invasion of Iraq and its aftermath. In the later congressional process, authorization for the program was combined 
with the overall 2004 spending bill, which was delayed for several months (for reasons having nothing to do with the MCA) until early 2004. In the meantime, as it awaited congressional approval, the administration announced detailed plans only for selecting countries and for creating the new corporation. It has held discussions, but not yet made final decisions about its plans for operations on the ground in recipient countries, program evaluation, or coordination with other existing US aid agencies, particularly USAID. Since the MCA now has received legal authority and funding, many of these details should become clearer during the first half of 2004.

Nevertheless, even if the program is implemented basically as designed, it will not address all criticisms of foreign aid. Most obviously, by introducing a new bilateral program, the MCA does little to improve the harmonization of aid programs. (Note that not all critics see too little harmonization as a problem. In particular, Easterly (2002) calls for more competition between donor agencies, rather than greater collusion. ) Indeed, there is a significant danger that the MCA could exacerbate the lack of coordination, both within the US government and across donor programs, as discussed below. Moreover, with the large amounts of aid involved, the MCA could make macroeconomic management more difficult for recipient countries, and could distort price incentives facing the private sector. Finally, only a small number of countries will qualify for the MCA, and the administration has not developed strategies for countries that do not qualify, or for failed states that might be the breeding grounds for terrorism and international crime.

\section{Narrower Objectives}

US foreign assistance programs, along with those from other governments, suffer from trying to do too many things at once. There are multiple objectives and purposes, often leading to a lack of coherence in everything from broad strategic planning to specific programs on the ground. For example, the US Foreign Assistance Act of 1961, as amended, specifies a remarkable 33 different goals and 75 priority areas for US foreign aid. The most obvious conflict for aid arises between diplomatic and security goals, on the one hand, and long term development goals on the other.

The tension between these goals is a prime reason why aid has had an uneven impact on growth and poverty reduction across countries. When legitimate security goals drive the allocation of resources (such as Cold War politics, or current funding for Pakistan as part of the war on terrorism), much less should be expected in terms of achieving development. It should hardly be surprising that aid delivered during the Cold War or to support Middle East peace has achieved little by way of development results, because that was not its chief goal.

The MCA's sharper focus on economic growth and poverty reduction is meant to reduce these tensions, although they can never be fully eliminated. As a result, the MCA should be able to allocate resources more effectively to meet those goals and allow for clearer evaluation of results, which should help ensure 
that both recipients and the American public get better outcomes from foreign aid. Of course, much depends on the extent to which the program is able to maintain its focus on growth, and is not used simply to support political allies (see Radelet (2003c) for a discussion of how the MCA fits into broader US foreign policy objectives, such as the war on terrorism). This, in turn, will depend on the process used to select countries for the program - the subject to which we now turn.

\section{Selecting for Success?}

A central tenet of the MCA is that aid can be more effective if it is focused on nations with governments that are committed to economic development and poverty reduction. This idea seems to make common sense: foreign assistance should go much further where governments are dedicated to building better schools and clinics, creating good jobs, and rooting out corruption than in countries with dishonest or incompetent governments. In reality, of course, whether or not the idea works in practice will depend on the details of implementation. 'Country selectivity' has gained much currency in recent years, based to a large extent on the research of World Bank economists Craig Burnside, David Dollar, and Paul Collier, which concludes that aid has a positive relationship with growth in countries with good policies and institutions, and little effect in other countries (Burnside and Dollar, 2000; Collier and Dollar, 2002; World Bank, 1998). However, these studies have come under attack from two directions. Several studies challenge the finding that the positive aid/growth relationship depends on good policies, finding instead that aid is positively correlated with growth (with diminishing returns) regardless of the policy environment (for example, Hansen and Tarp, 2000). Other studies have found that the initial results are not robust to new data points and different time frames, and do not find a clear relationship between aid and growth (Easterly, Levine and Roodman, 2003).

While the statistical debate continues, the 'country selectivity' idea seems intuitively correct to development specialists, from a variety of backgrounds, who believe that aid is more likely to work in countries with governments that are committed to development - including some aid critics. For example, few believe that aid did any good in Zaire under the disastrous leadership of Mobuto Sese Seko, while aid played an important supporting role in well-governed Botswana's very rapid development. Hughes (2003) argues that 'AusAID's best projects and programmes have been in countries like Thailand and Indonesia that were sharply focused on growth in the 1970s and 1980s'. Partly because of these beliefs, the Burnside, Dollar and Collier research has heavily influenced several donors, including the World Bank, the Asian Development Bank, and the African Development Bank. All three banks have adopted a Performance-Based Allocation (PBA) system for distributing their concessional loans among eligible borrowers. In the World Bank, a country's allocation depends primarily on its Country Policy and Institutional Assessment (CPIA) score, through which Bank staff rank countries on 20 different policy and institutional criteria. Other factors 
determining allocation are the performance of the country's loan portfolio with the Bank, its average income, and its population (World Bank, 2003a and 2003b). The Asian and African Development Banks use similar, albeit not identical, systems (Asian Development Bank, 2001; African Development Bank, 2001).

There is no question that the idea of 'country selectivity' and the Burnside, Dollar and Collier research is at the core of the MCA country selection process. However, the general idea that good policy matters in making aid more effective only takes us so far. Putting this idea into practice raises an immediate challenge: how should donors determine whether potential recipient countries meet this standard? This question has been the focus of much debate on PBA systems at the multilateral development banks (MDBs), particularly on the choice of indicators, their measurement, weighting, and exceptions to the rules. With respect to the MCA, specifically, are President Bush's criteria of 'ruling justly, investing in their people, and establishing economic freedom' the right ones? And if so, how, precisely, should the US government determine which countries meet these criteria?

At the most general conceptual level, it is hard to argue against Bush's three broad criteria. Surely donors should be inclined to provide more support, all else being equal, to countries with better governance - in the sense of a lower level of corruption, more effective government, and stronger support for democracy. Moreover, recent empirical suggests that countries with better governance have better development outcomes, in the sense of faster economic growth, increased adult literacy, and lower infant mortality (Kaufmann, Kraay and Zoido-Lobatón, 1999). ${ }^{1}$ Similarly, few development experts would argue about the merits of lowincome countries 'investing in their people' to the extent that means investments in basic health and education. 'Investing in economic freedom' is more contentious: although there clearly has been a consensus to move toward more open and flexible markets in low-income countries during the last two decades, debate continues on how far this trend should go and which markets should be liberalised. In all three areas, then, the devil is in the details, as has been discovered in other PBA systems. While most development experts would not argue forcefully against the broad thrust of the three criteria, all would ask: precisely what do they mean, and how should they be measured?

To address this issue, the administration will use 16 specific indicators (see Table 1), grouped into Bush's three broad categories. According to the administration's methodology, countries must score above the median (calculated for all broadly eligible countries) on half or more of the indicators in each of the three groups to qualify for the MCA. That is, countries must surpass the median

1 As with any relationship, there are some exceptions to the rule. Some analysts point to China as a country with poor governance and strong development outcomes. China does score poorly on democracy-related indicators, but on other governance indicators (for example, political stability, government effectiveness, corruption, regulatory quality, and even rule of law), it scores well above the average for countries at similar levels of income (see World Bank Institute governance database at http://www.worldbank.org/wbi/governance/govdata2002/index.html). 
in three of the six 'ruling justly' indicators, two of the four 'investing in people' indicators, and three of the six 'establishing economic freedom' indicators. In addition, a country must score above the median on corruption, regardless of how well it does on all the other indicators.

Table 1: Eligibility Criteria for the MCA

\begin{tabular}{|c|c|}
\hline Indicator & Source \\
\hline \multicolumn{2}{|c|}{ I. Ruling Justly } \\
\hline 1. Control of Corruption & World Bank Institute \\
\hline 2. Rule of Law & World Bank Institute \\
\hline 3. Voice and Accountability & World Bank Institute \\
\hline 4. Government Effectiveness & World Bank Institute \\
\hline 5. Civil Liberties & Freedom House \\
\hline 6. Political Rights & Freedom House \\
\hline \multicolumn{2}{|c|}{ II. Investing in People } \\
\hline 7. Immunization Rate: DPT and Measles & WHO/World Bank \\
\hline 8. Primary Education Completion Rate & World Bank \\
\hline 9. Public Primary Education Spending/GDP & World Bank \\
\hline 10. Public Expenditure on Health/GDP & World Bank \\
\hline \multicolumn{2}{|c|}{ III. Economic Freedom } \\
\hline 11. Country Credit Rating & Institutional Investor \\
\hline 12. Inflation & IMF \\
\hline 13. Regulatory Quality & World Bank Institute \\
\hline 14. Budget Deficit/GDP & IMF/World Bank \\
\hline 15. Trade Policy & Heritage Foundation \\
\hline 16. Days to Start a Business & World Bank \\
\hline
\end{tabular}

Note: To qualify, countries must be above the median on half of the indicators in each of the three sub-groups, and above the median on corruption.

Source: 'Fact Sheet: Millennium Challenge Account', distributed by the administration on 25 November 2002, available at www.cgdev.org.

Using publicly available data and this methodology on the administration's 16 indicators, I have produced an illustrative list of countries that are most likely to qualify for the MCA during its first three years (see Radelet (2003b) for more details on the 16 indicators and the methodology). It is crucial to note that this list is illustrative, rather than official US policy. Although the administration has 
announced that it will follow this procedure in choosing the countries, it has not yet announced its list of qualifying countries, and the list that it ultimately announces (sometime in early 2004) is likely to differ from this illustrative list in some instances.

Moreover, the administration has stressed that the list produced by the 16 indicators is not final - the board of directors of the new Millennium Challenge Corporation (MCC), which will be explained below, can modify the final list under certain circumstances (see the administration's fact sheet at www.cgdev.org/nv/MCA_FactSheetNov.doc). Specifically, in making its final decisions, the board will be 'empowered to take account of data gaps, lags, trends, or other material information, including leadership, related to economic growth and poverty reduction'. This last step introduces some subjectivity into the selection process, which is probably necessary given the weaknesses in the data. However, this discretion opens up the possibility that the ultimate list of qualifying countries will become politicised. There is little question that, to some degree, some pressure to put political allies on the eligibility list is inevitable. But the system has some checks and balances that will modify this impulse in key ways. Most importantly, the administration has announced a very public, transparent system, using public data (not secret US data) to choose the baseline list of countries. To the extent that it deviates form this list, it will have to answer to public scrutiny from Congress and other interested parties. ${ }^{2}$ This public check will not completely stop the administration from making some changes, but it will make it much more difficult, and should modify abuse in the selection process to some extent.

Despite these possible adjustments, the illustrative list determined by the most recent data provides some useful insight as to how the MCA might eventually develop. In the first year, the pool of countries eligible for consideration for the MCA are those with an average annual per capita income below \$1,435 and that are eligible for concessional borrowing from the World Bank. There are 74 countries in this group. Table 2 shows that 11 of these countries might qualify for the MCA during this period, based on data currently available and a strict interpretation of the administration's qualifying procedures. The table also shows that several other countries are very close to qualifying. Three more countries would qualify if the administration slightly altered its criteria to allow scores equal to the median count as passing scores, rather than strictly above the median. Five other countries pass sufficient hurdles, but fail on the corruption indicator - the one indicator that countries must pass in order to qualify. Eight other countries miss qualifying by one hurdle. Thus, the number of qualifying countries easily could expand beyond the 11 that strictly meet the criteria in the first year.

\footnotetext{
${ }^{2}$ This public selection system is one way in which the MCA goes beyond the multilateral development banks' PBA system, since the MDBs' country policy performance scores are not publicly available.
} 
Table 2: Possible Qualifying Countries Using the Administration's Criteria

\begin{tabular}{|c|c|c|c|}
\hline & $\begin{array}{l}\text { Year 1: IDA Eligible } \\
\text { Countries with per } \\
\text { Capita Incomes Less } \\
\text { Than } \$ 1,435\end{array}$ & $\begin{array}{l}\text { Year 2: } \\
\text { Countries with per } \\
\text { Capita Incomes Less } \\
\text { than } \$ 1,435\end{array}$ & 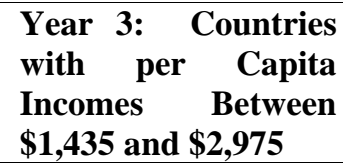 \\
\hline \multicolumn{4}{|c|}{ Qualifying Countries } \\
\hline 1. & Armenia & Armenia & Belize \\
\hline 2. & Bhutan & Bhutan & Bulgaria \\
\hline 3. & Bolivia & Bolivia & Jordan \\
\hline 4. & Ghana & Honduras & Namibia \\
\hline 5. & Honduras & Lesotho & South Africa \\
\hline 6. & Lesotho & Mongolia & St. Vincent \& Grenada. \\
\hline 7. & Mongolia & Nicaragua & \\
\hline 8. & Nicaragua & Philippines & \\
\hline 9. & Senegal & Senegal & \\
\hline 10. & Sri Lanka & Sri Lanka & \\
\hline 11. & Vietnam & Swaziland & \\
\hline 12. & & Vietnam & \\
\hline \multicolumn{4}{|c|}{ Eliminated By Corruption } \\
\hline 1. & Albania & Bangladesh & Romania \\
\hline 2. & Bangladesh & Ecuador & \\
\hline 3. & Malawi & Malawi & \\
\hline 4. & Moldova & Moldova & \\
\hline 5. & Mozambique & Paraguay & \\
\hline 6. & & Ukraine & \\
\hline \multicolumn{4}{|c|}{ Missed by One Indicator } \\
\hline 1. & Benin & Benin & Maldives \\
\hline 2. & Burkina Faso & Burkina Faso & Thailand \\
\hline 3. & Cape Verde & Cape Verde & Tunisia \\
\hline 4. & Georgia & The Gambia & \\
\hline 5. & Guyana & Ghana & \\
\hline 6. & India & Guyana & \\
\hline 7. & Mali & India & \\
\hline 8. & Mauritania & Mali & \\
\hline 9. & Nepal & Mauritania & \\
\hline 10. & Sao Tome and Principe & Morocco & \\
\hline 11. & Togo & Sao Tome and Principe & \\
\hline \multicolumn{4}{|c|}{ Eliminated for Statutory Reasons } \\
\hline 1. & & China & \\
\hline 2. & & Syria & \\
\hline
\end{tabular}

Source: Radelet (2003b). 
The pool of eligible countries will expand slightly in the second year, in line with an increase in program funding to include all countries with average per capita income below $\$ 1,435$, regardless of their borrowing status with the World Bank. This change increases the total number of eligible countries to 87. Of these, 12 qualify in the second year according to a strict interpretation of the process. An additional 17 countries just miss qualifying, either because some of their scores are equal to the median, they fail on corruption, or miss by a single indicator.

The administration proposes sharply expanding the pool of eligible countries in year three (in line with the increase in annual funding to the targeted $\$ 5$ billion) to include the 28 nations with average per capita incomes between \$1,435 and $\$ 2,975$. This group of countries would be judged separately from the 84 countries with average incomes below $\$ 1,435$, with separate median scores to assess country qualification. Adding this last group of nations is controversial, with some analysts (including me) believing that the program should remain focused on the poorest, least developed countries of the world, and should not be expanded to countries that have access to private capital markets. In any case, based on data available today, six of these 28 nations would qualify in year three, as shown in Table 2, and four others would be close to qualifying. Note that these countries are in addition to those that qualify in year two (not instead of), since they compete to qualify as a separate group.

Thus, based on a strict interpretation of the administration's proposal, approximately 18 different countries might qualify for the MCA over the course of the first three years. More than 20 other countries might miss qualifying by just one indicator. Several of these countries could easily qualify within the first few years by improving their scores in one deficient area. Thus 20-25 countries could qualify for the MCA by its fourth or fifth year of operation.

The relatively large MCA budget, combined with the small number of qualifying countries, should provide ample incentive for countries to try to qualify. For the first year, Congress has approved $\$ 1$ billion in funding. If the administration's list of first-year qualifiers ultimately includes, say, 15 countries, the average country could receive $\$ 67$ million. This is equivalent to about onesixth of the average total capital inflows (from aid and other sources) of \$384 per country for IDA-eligible countries (Radelet, 2003b). Ultimately, if the MCA receives a total budget of, say, $\$ 3$ billion (a figure more likely than the $\$ 5$ billion proposed by the president), and 25 countries qualify, the average per country would reach \$120 million per year, equivalent to about one-third of current capital inflows.

This list of countries is not perfect, but it is a reasonable start towards the objective of a selective program. Weaknesses and inconsistencies in the data result in some countries appearing on the list that probably should not qualify, and a few nations do not appear despite having a strong record of using aid effectively. Some changes to the criteria could improve the list. For example, some of the weakest indicators (such as the trade index) could easily be improved over time. The aggregation methodology of counting the number of median scores surpassed 
could be replaced with a simple aggregation method of normalizing scores and then adding them into a composite score, which (while not perfect) would lead to fewer anomalies. In addition, the requirement to exclude all countries with corruption scores below the median should be modified, since the underlying data are not sufficiently robust to make such clear judgments. These and other proposals to improve the selection procedure are discussed in detail elsewhere (Radelet, 2003b). Moreover, using such a highly selective process means that many poor, weakly governed countries are unlikely to qualify for the MCA, making it all the more important for the US to improve its other aid programs, as discussed below. Nevertheless, despite these issues, the proposed system provides a reasonable way to begin distinguishing between nations that show a strong commitment to development and those that do not.

\section{Beyond Selection: Improving the Aid Bureaucracy}

The US foreign aid system is bogged down under a heavy bureaucracy, overly restrictive legislative burdens, and conflicting objectives. As with most donors, the US delivers aid in basically the same way in countries with competent, committed governments as in countries with high levels of corruption and poor development policy. To make the MCA different, the Bush administration has proposed that the program be administered through a new 'government corporation' - the Millennium Challenge Corporation (MCC) — designed to reduce administrative costs and increase effectiveness.

Details on the structure and operations of the MCC are beginning to emerge. The MCC will be governed by a cabinet-level board of directors chaired by the secretary of state and including four non-government appointees, two nominated by each of the majority and minority parties in Congress. The Corporation will be managed by a CEO nominated by the president and approved by the Senate. Staff will be drawn from a variety of government agencies for a limited term. The MCC's biggest advantage is that it would start with a clean slate, and therefore could avoid the bureaucratic procedures and multiple congressional mandates that weaken current aid programs. Its status as separate from any existing department could make it more flexible and responsive, and could help it to attract some topnotch talent.

Establishing a new corporation entails certain risks, however. Dividing the US foreign-assistance program into two major agencies (USAID and the MCC), in addition to several smaller agencies such as the Peace Corps, could impede coordination and increase redundancy. For this reason, many advocates preferred the option of making the MCA a subset of USAID, in order to keep the major aid programs under one leader. Ultimately, however, the administration believed that this structure would undermine the MCA, by subjecting it to the rules and regulations of USAID. Another risk is the size of the MCC staff. The administration hopes to keep MCC small, but its projected staffing level of somewhere between 100 and 200 people seems inordinately so for a program with an annual budget of $\$ 5$ billion. It is also not clear who will represent the MCC on 
the ground in the qualifying countries. Presumably, it will contract out many services, such as monitoring and evaluation, or it might try to work through USAID staff in each country. Nevertheless, there is a risk that the new agency will be understaffed and thus unable to deliver the high-quality operations that will be expected. In addition, having the secretary of state serve as chairman of the board of the MCC could give the department too much control over qualification and allocation decisions, which could compromise the objectivity of the MCC in favour of other foreign policy goals. In short, over time the MCC could be facing all of the same obstacles that are currently facing USAID, especially if the administration does not try to rectify the weaknesses within USAID itself in the meantime.

One of the biggest concerns, therefore, is the impact of the MCC on USAID and the relationship between the two organizations. The MCC is likely to draw staff and resources from USAID, furthering weakening the agency, possibly engendering some resentment, and making cooperation more difficult. Many issues remain uncertain. For example, will USAID continue to operate in the MCA countries, or will it pull out once a country qualifies? On the one hand, having both institutions operating in the same country could be very confusing for recipient countries and unnecessarily duplicate services. On the other, there may be some projects and programs that USAID is better positioned to administer, given its prior experience and established operations in these countries. This issue could prove particularly tricky for borderline countries that qualify for the MCA for several years, then fail to qualify, and then qualify again. Switching back and forth between MCA and USAID programs could be very cumbersome. Similarly, will the MCC operate under new or existing foreign assistance guidelines for procurement of goods and services and other operations? Although more flexible guidelines might seem useful for the MCC, if the two agencies are operating under vastly different rules in the same country, this could lead to serious confusion.

The administration has not yet addressed these questions. If not resolved carefully through strong planning and coordination, the difficulties in operating two foreign assistance programs from two very different parts of the US government are sure to become apparent, and could significantly undermine both MCA and USAID programs.

\section{Designing Better Programs}

Currently, most US foreign assistance is delivered through a countryprogramming approach in which USAID staff members develop a country strategy, design specific interventions, and evaluate the outcomes. This top-down approach has many shortcomings, including the absence of recipient-nation ownership of specific projects, only partial coordination (at best) with the recipient country's overall development strategy, a heavy requirement of USAID staff, and little competition between proposed projects. The administration is planning a different approach with the MCA — building on the basis that MCA-recipient 
nations have an established record of good development policies - that would give recipients much more of the responsibility for program design.

Although details are still under discussion, one possibility is to draw on the 'foundation approach' in which recipients write proposals for various activities and the best ideas receive funding. In this process, the government of an MCA country could write a proposal, for example, to fund a significant portion of its education program. Proposals would spell out the specific actions that the recipient would take and the benchmarks by which success would be measured, pushing recipients to establish concrete goals. In one variation under consideration, government and non-government agencies alike — such as private NGOs, clinics and schools - could write proposals and receive funds, since private agencies implement some of the best development programs.

The foundation approach is already being used by some other new aid organizations, including the Global Alliance for Vaccines and Immunizations (GAVI) and the Global Fund to Fight AIDS, Tuberculosis, and Malaria. This approach would provide a process through which the US government could provide direct budget support (under the right circumstances) and finance development programs (including recurrent costs) in addition to specific projects. It also would be consistent with the recent movement of other donors toward 'pooling' of funds and towards Sector-Wide Approaches (SWAps) to financing health and education programs.

Such an approach would place responsibility for development programs where it belongs - with recipient nations, not with aid agencies. It would ensure that recipient governments set their own priorities and develop their own strategies. If this approach were implemented in a serious, non-superficial way, the MCA would increase recipient-nation ownership of, and commitment to, development programs, which could lead to better results. Some analysts have argued that many MCA countries will initially lack the capacity to develop strong proposals and programs, but the only way they will develop these capacities is if they are given the responsibility to do so and expected to show results. Obviously this approach can only work in those countries that have shown, and continue to show, a real commitment to development, and it will only work if recipients are truly held accountable for results.

Thus the final, and perhaps most crucial, element for the MCA to succeed is a serious monitoring and evaluation (M\&E) process. Most aid agencies have weak and superficial M\&E processes, and if the MCA follows this pattern it is doomed to fail. Effective M\&E is critical for keeping funded programs on track to meet their goals, guiding the allocation of resources towards successful activities and away from failures, and ensuring that the lessons learned from ongoing activities - both successes and failures - inform the design of new projects and programs.

Two distinct kinds of M\&E are required: tracking finances and monitoring substantive targets. Financial accountability should ensure that funds are spent where they are supposed to be spent, projects remain within budgets, regulations on procurement and payment are followed, and funds are not stolen. Substantive accountability focuses on attaining specified benchmarks, such as training so 
many teachers, building a designated number of schools, or increasing test scores by a certain amount. M\&E must be incorporated into projects and programs from the outset, not added on as an afterthought halfway through the process. Both internal audits (carried out by the grantees) and external audits (carried out directly by the MCC or a contractor to the MCC) will be needed to ensure compliance and high standards. A small number of programs should be evaluated through randomised trials, as suggested by Kremer (2003) and others.

Of course, providing recipients with a greater say in program design, implementation, and evaluation entails some risks. Giving recipients greater flexibility can only work in countries that demonstrate the strongest commitment to development - exactly the MCA's target countries. With greater flexibility, however, should come greater responsibility. The US should expect strong results from the MCA, and hold grantees accountable for achieving the goals specified in their programs. It should generously fund programs that achieve results, and reduce or eliminate funding for programs that do not. Whether or not the MCA can ultimately move in this direction remains to be seen. If it can, it could lead to positive changes in US and other aid programs; if it cannot, it could quickly begin to resemble most other aid programs.

These issues and concerns go well beyond the MCA, since introducing a new MCA (even if it runs well) will not constitute a complete foreign assistance strategy for the US. Since only a small number of countries will receive MCA funding, the new program is at best only a partial strategy for US foreign assistance. Indeed, because the MCA focuses on those countries with governments that have shown the strongest commitment to development, it essentially deals with the easiest cases among poor countries.

To really make US foreign aid work effectively, the Bush administration must develop comparable strategies for different groups of nations that fail to qualify for MCA funding, whether they just miss qualifying or are failed states mired in perpetual conflict. Different approaches are required for different circumstances, with varying design procedures, delivery mechanisms, objectives and $M \& E$ processes. For example, in countries that just miss qualifying for the MCA, allowing recipients to write limited proposals focused on the specific areas where they fall short of qualification could strengthen traditional aid programs. In countries with weaker governments, donor funding should continue to concentrate on specific projects, but with streamlined contracting and procurement procedures to make projects more cost-effective. Where governments are weak (or part of the problem), aid should be channelled through NGOs and other service providers on the ground. In some circumstances, no aid should be provided at all. In effect, the MCA should be seen as just one of several tools available to address US goals in low-income countries.

\section{A Unilateral Approach}

There are in fact two major Bush administration foreign aid initiatives: the MCA and the 'Emergency Plan for AIDS Relief', which will provide $\$ 10$ billion over 
the next five years (in addition to $\$ 5$ billion already in the pipeline) to fight HIV/AIDS around the world, with a special focus on Africa and the Caribbean. All of the MCA money and over 90 per cent of the HIV/AIDS funds will go through US bilateral programs. The unilateral nature of these initiatives reveals the administration's distrust of both its own institutions and multilateral aid agencies.

With the MCA the administration could have spearheaded a multilateral initiative with the same basic design: choosing countries selectively, delivering aid more efficiently with more recipient-country input, a smaller bureaucracy, and results-based management. There are three likely reasons that it chose the unilateral route:

- Political. In the face of mounting criticism that the US does too little to fight global poverty, the administration wanted to announce a significant, clearly American initiative at the International Conference on Financing for Development in Monterrey in March 2001. A multilateral effort, even if spearheaded by the US, quickly would have lost much of its brand identification as a US initiative.

- Substance. In two key areas of the MCA - country selection and the expectation of results - the administration does not trust the multilateral institutions to maintain high standards. It is not convinced by the World Bank's claims that it has become more selective in its allocation decisions. Many in the administration believe that to turn the MCA over to a multilateral organization would doom it to large bureaucratic costs and weak results. In the administration's view, the US would be expected to be the largest donor but would cede much of its control to the other donors. In a unilateral approach, the US can maintain complete control over all aspects of the program. Hughes (2003) makes a similar argument about Australian aid, concluding that the bulk of it should be provided unilaterally, as she believes the multilateral institutions have failed to maintain high standards.

- Ideological. The unilateral approach to foreign aid is part of a much larger pattern of the administration's scepticism of multilateral approaches to foreign policy. There are many other examples, including terminating negotiations on the Kyoto Protocol on Climate Change, rejection of the Rome Statute of the International Criminal Court, and withdrawal from the antiballistic missile (ABM) treaty.

The main arguments in favour of a multilateral approach for the MCA are laid out by van de Walle (2003) and Sperling and Hart (2003). First, a multilateral approach would be less cumbersome and confusing to recipient countries that are overwhelmed by the myriad proposal processes, financial mechanisms and reporting systems used by different donors. Second, it would create more leverage for US funds, since other donors would contribute something for each dollar the US spends. Third, a multilateral approach would reduce the pressure to allocate funds on a political basis (although the MCA's public selection process goes some 
distance toward easing this concern; moreover, multilateral organizations are far from immune to political pressures). Fourth, a multilateral approach would be less immune to earmarking, tied aid, and other burdens imposed by Congress, although it would be subject to its own bureaucracy.

Despite these concerns, under a best-case scenario it is possible that a unilateral MCA could have a positive impact on other donors and on donor harmonization. By itself, the MCA, at \$5 billion, will account for the equivalent of 9 percent of current worldwide ODA flows of $\$ 58$ billion - not an overwhelming share, but far from insignificant. Its proposed recipient-driven, program-based approach could influence other donors to try similar strategies. Moreover, recipient proposals used for the MCA could be the basis for other donors to co-finance the same activities. For example, consider the Education for All (EFA) initiative, in which donors agreed in 2000 to provide funding for countries that produced strong education strategies. The EFA strategies could be the basis for MCA funding in qualifying countries, with the US and other donors cooperatively financing parts of the same basic education plan.

Much will depend on the extent to which the new corporation is willing to work cooperatively with recipient governments and other donors to reduce the administrative burden on aid recipients. If the US stridently insists on using its own unique proposal format and reporting systems the MCA will set back recent efforts to improve coordination, and could become a stumbling block for greater harmonization. If, however, there is a serious effort to establish rigorous procedural norms that a majority of donors can accept, including expecting high performance standards, the MCA could be a small step in the right direction of improving donor harmonization and the performance of foreign aid .

The MCA is only in its very initial stages, having finally received approval and budgetary authority for its first year of operation. Many aspects of the program are promising: its de-politicised country selection process (which should moderate, albeit not fully eliminate, political pressures in the selection process); its relatively large funding ( $\$ 1$ billion in the first year); its country-owned proposal process; and its emphasis on achieving results. Of course, there is a very real possibility that the program will not live up to its promise, and will ultimately operate like many other aid programs, so some scepticism is warranted. But the MCA clearly signals a fundamental shift in the thinking behind US foreign aid programs, holding out the possibility of larger and more effective foreign aid in the years to come. Working to achieve that goal is surely in America's best interests, as well as in the interests of low-income countries around the world.

\section{References}

African Development Bank (2001), 'Performance-Based Allocation of ADF Resources', www.adb.org/Documents/Policies/ADF/Performance_Based_Allocation/.

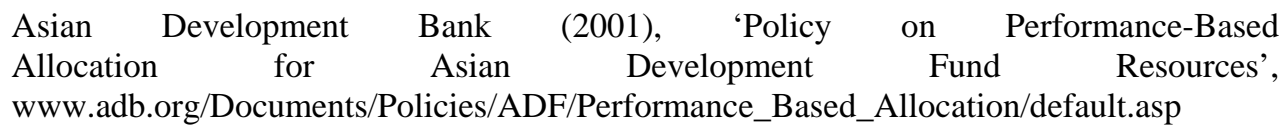


AusAID (2003), 'Why our AID to the Pacific is so Important', www.ausaid.gov.au/hottopics/topic.cfm?Id=2157_7967_5228_415_6958.

Burnside, C. and D. Dollar (2000), ‘Aid, Policies, and Growth', American Economic Review 90(4)(September):847-68.

Collier, P. and D. Dollar (2002), 'Aid Allocation and Poverty Reduction', European Economic Review 45(1):1-26.

Easterly, W. (2002), 'The Cartel of Good Intentions: Bureaucracy versus Markets in Foreign Aid', Working Paper No. 4 (March), Center for Global Development, Washington DC.

Easterly, W., R. Levine and D. Roodman (2003), 'New Data, New Doubts: Revisiting 'Aid, Policies and Growth”, Working Paper No. 26 (February), Center for Global Development, Washington DC.

Hansen, H. and F. Tarp (2000), 'Aid Effectiveness Disputed', Journal of International Development 12(3):375-98.

Hughes, H. (2003), 'Aid has failed the Pacific', Issue Analysis No. 33, The Centre for Independent Studies, www.cis.org.au/IssueAnalysis/ia33/ia33.htm.

Jempa, C. (1991), The Tying of Aid, OECD Development Center, Paris

Kaufmann, D., A. Kraay, and P. Zoido-Lobatón (1999), 'Governance Matters’, Working Paper 2196 (October), Policy Research, World Bank, Washington DC.

Kremer, M. (2003), 'Randomized Evaluations of Educational Programs in Developing Countries: Some Lessons’, American Economic Review 93(2)(May):102-106.

Radelet, S. (2003a), 'Will the Millennium Challenge Account be Different?', The Washington Quarterly (Spring):171-188.

Radelet, S. (2003b), Challenging Foreign Aid: A Policymakers Guide the to Millennium Challenge Account, Center for Global Development, Washington DC.

Radelet, S. (2003c), 'Bush and Foreign Aid', Foreign Affairs 82(5) (September/October):104-117.

Sperling, G. and T. Hart (2003), 'A Better Way to Fight Global Poverty: Broadening the Millennium Challenge Account, Foreign Affairs 82(2) (March/April): 9-14

Van de Walle, N. (2001), African Economies and the Politics of Permanent Crisis, 19791999, Cambridge University Press, Cambridge.

Van de Walle, N. (2003), 'A Comment on the MCA Proposals', Center for Global Development, Washington DC, www.cgdev.org/briefs/vandewalle_20030109.pdf.

World Bank (1998), Assessing Aid: What Works, What Doesn't, and Why, World Bank, Washington DC. 
World Bank (2002), A Case for Aid: Building a Consensus for Development Assistance. World Bank, Washington DC.

World Bank (2003a), 'IDA's Performance-Based Allocation System: Current and Emerging Issues', Report No. 27082 (October), World Bank, Washington DC, wwwwds.worldbank.org/servlet/WDS_IBank_Servlet?pcont=details\&eid=000160016_2003102 7122520 .

World Bank (2003b), 'Allocating IDA Funds Based on Performance: Fourth Annual Report on IDA's Country Assessment and Allocation Process', World Bank, Washington DC, (April), siteresources.worldbank.org/IDA/Resources/PBAAR4.pdf

Some parts of this paper are drawn from an earlier paper 'Will the Millennium Challenge Account be Different?' The Washington Quarterly, Spring 2003:171188, and from 'Challenging Foreign Aid: A Policymakers Guide the to Millennium Challenge Account' published by the Center for Global Development (Washington, DC). My thanks to Ross McLeod for suggesting I write this article, and to two anonymous referees whose generous comments improved the quality of the final product. 



\title{
REVIEWS
}

\section{Regulating Government Enterprises}

\author{
Michael Whincop (ed.), From Bureaucracy to Business Enterprise: Legal \\ and Policy Issues in the Transformation of Government Services, \\ Ashgate, Hampshire, UK, 2003
}

\section{Review by Gary Johns}

$\mathrm{P}$ ublishers will tell you that a book of conference papers is hard to sell, and editors will tell you that a book of conference papers is hard to review. The latter, even more so when three of the papers are comments on other papers. Publishers and editors are generally right - they have to be because they are paid to know their market. This is a useful starter for the review of an edited book about the regulation of Government Business Enterprises and Government Operated Corporations (GOCs). The contributors jump between the two terms, so for the purposes of the review the generic GOC will suffice. The issue for all of the contributors is to decide how public or private are GOCs, and having decided, to be satisfied that each is sufficiently accountable to the appropriate power, the government and/or the market.

The contributors appreciate the dangers of bureaucratic inefficiency and party-political manipulation in the governance of GOCs on the one hand, and the emulation of private sector management on the other. It is not difficult to be left with the impression however, that the complexities of designing accountability systems for GOC performance are such that, in the absence of overwhelming economic argument, like the presence of a natural monopoly, it is better to privatise than to corporatise. If a GOC cannot serve two masters, the private interest and the public interest, then best to sell and let government concentrate on regulating the market, not the GOC. I suspect that most of the authors in the volume would not be in the privatisation camp. In fact, at the outset while the editor claims to have no preference for state control over government control of economic enterprises, those in favour of market processes are described as 'ideologues of the Right' whereas the statists are assumed to be normal.

There are three classes of contribution; we will name them, reactionary, sceptical, and accepting. Only the latter seem to be aware that Australian GOCs have turned from being a net drain on government budgets to a net contributor in the space of two decades, that many of those privatised are making a significant contribution to the economy, and subsidies for public purposes once associated with GOC pricing are more explicit. The reactionary contributions begin with the presumption for continued public ownership and argue that privatisation is not a continuous evolution of economic policy, but that in the economies surveyed - 
Australia, UK, US - despite the fact that there have been 'slash and burn turn(s) of the cycle' of ownership, there should be no presumption that government will vacate the field. The governments in the countries surveyed may have vacated the field of economic ownership, but there is no suggestion that they have vacated the regulation of the marketplace, nor (often at the behest of the electorate) most other aspects of life. A second contributor wants to start a 'counter reformation' and have the market well and truly subsumed by politics. He confuses the ability to charge a commercial price with a lack of public accountability. 'Increases in profitability arise precisely because managers are not subject to constraints imposed through public accountability, and are therefore free to manage enterprises so as increase revenue and reduce costs'. It could be argued that price is a form of public accountability, and that to this author accountability really means hidden subsidy.

The sceptics have a problem specifying the 'public interest'. One asks, 'how can managers of GOCs be motivated to act in the broader interests of society? For example, 'Governments may like the [GOC] to operate efficiently, in the sense of producing its relevant outputs at the lowest possible cost. However, governments may also be concerned about unemployment. If efficient operation of the [GOC] involves a significant reduction of the workforce and a rise in unemployment, these two objectives will conflict'. This is surely a confusion of the enterprise with the economy. If in the short run a government uses its own enterprises to bolster employment in an inefficient operation (or indeed in protecting a private one) it will in the long run the risk of leading to higher unemployment.

One of the important innovations of the corporatisation period has been not only the discipline of the market on enterprises, but also the discipline on politicians of specifying non-economic objectives, or economic objectives broader than the enterprise. One contribution produces a survey of members of various boards of Queensland GOCs, which indicates difficulties in Ministerial intervention in the affairs of the GOC. For example that the Minister-asshareholder may promote electoral maximising rather than wealth-maximising behaviour. Quite so, but if the 'public interest' is to be achieved, it is difficult to state who else other than the Minister may be in a position to know the public's interest. A useful suggestion may be to insulate a GOC from certain excesses of ministerial intervention, for example, when a Minister holds down insurance premiums for workers' compensation until after an election, by ensuring the premium setting process is transparent. A high degree of specification of governance parameters - that is, setting out a thorough menu of performance on non-financial criteria, or community-service-obligations - is a desirable thing, but is unlikely to prevent a Minister from asserting that his interventions are in the public interest. However, one of the interlocutors advises, 'A risk of inappropriate Ministerial intervention may be the price we pay for the opportunity for appropriate intervention'.

Another contributor criticises the perennial Productivity Commission critique that GOCs are not efficient, and supports Senator Stott Despoja's suggestion of a Public Interest Commission! Why not just get rid of government altogether, 
which I suspect is the entire purpose of the governance discourse that has crept into political-economy in the last decade. It is as if the underlying objectives of GOCs are only social. It may be more helpful to commence with the assumption that their objectives are economic, and then specify the non-economic objectives and preferably implement these available outside of the operation of the GOC.

Another discusses as a case study the Energy and Water Ombudsman Victoria, and questions whether the privately funded (by licence holders) structure can be part of the doctrine of responsible government. The assertion is that energy and water are public goods, which the state has chosen to deliver privately, but that the 'provision of essential services is properly situated in the public realm'. Surely, the issue is not what the state wants, but what the customers want, presumably a good service at best price. What were once deemed essential services are clearly no longer public goods.

There is a presumption that 'market governance'- governments letting go of economic entities (but not of regulation) - is tantamount to the 'fraying of Ministerial accountability'. The presumption is that the consumer, for the purposes of goods and services provided by a GOC, is also a citizen. Hence, the call for direct accountability of the scheme by 'consumer/citizens'. This would involve the election of consumer representatives by their relevant constituencies, which in practice usually means the funding of consumer advocacy groups and their pet projects.

In terms of the dispute resolution processes available for contracted parties and consumer/citizens, the contribution kindly presents an alternative view, in the form of a judge's remark. 'The courts have not taken the view that a privately founded, privately managed organisation ... is necessarily to be subject to control by the courts. That is certainly not to say that such an organisation may treat itself as above the law; it is merely to acknowledge that the courts will not discourage private organisations from ordering their own affairs within acceptable limits'. Quite so.

There are contributions that accept corporatisation and who wish to enhance its usefulness with suggested reforms that may help achieve some of the benefits of market-based governance without giving up governmental control. 'Sometimes these benefits are best achieved by replicating the governance of private firms'. One contributor addresses the problems of managerial agency costs and inappropriate Ministerial intervention with a number of innovative strategies.

The first is a contractual solution, to let parties resolve issues contractually without legislative intervention. In fact, the contract may be part of legislation, but a particular device such as an appropriately crafted Statement of Corporate Intent, may go a long way to solving the issue of the divergent interests of a Minister in the responsibility for a GOC. Another, quite intriguing gambit, is to create a class of private investors with a stake in the GOC by the issue of subordinated debt. The idea is to create an investor class that has an incentive to monitor and whose purchase and sale decisions provide a market signal about the GOC performance. Other contributors suggest ways to define those who should 
have standing to sue a GOC in private actions, to mimic the environment of the private firm.

Such suggestions seem to be greatly advanced in the exercise of accepting the presence of government-owned corporations in the market place and creating the best opportunity for them to perform as economic entities, rather than the reluctant starters who would rather 'social' objectives be achieved by economic entities. The difficulty for the reluctant corporatisers is that, the more corporate responsibilities are loaded onto GOCs, the greater the reason to privatise. The desire to account for each potential adverse aspect of the market, by incorporating into the governance of every GOC, every conceivable fail-safe arrangement, rather defeats the purpose of the corporatisation. Those who want to broaden the scope of corporate governance by incorporating the political agendas subsumed under corporate social responsibility only serve to produce a strong argument to allow the GOC to escape the clutches of government, and at least then face merely the competition of its peers and the ordinary weight of regulation.

In essence, the dominant contributions in the book reflect the prevailing orthodoxy of the Griffith University Key Centre for Ethics, Law, Justice and Governance: that we live in a post-parliamentary, post-democratic, post-market age; that the combination of representative government and the regulated market are insufficient to deliver a just outcome for everyone. Rather than the liberty to make ones own way in the world, the dominant value is that every citizen has recourse to every forum to resolve his or her every problem, and that every problem is public and shared by every other citizen. I guess they know their market.

Gary Johns is Senior Fellow, Institute of Public Affairs. 


\title{
In Praise of Globalism
}

\author{
Mike Moore, A World Without Walls: Freedom, Development, Free \\ Trade and Global Governance, Cambridge University Press, \\ Melbourne, 2003
}

\section{Review by George Fane}

$\mathrm{M}$ ichael Moore, who was once briefly prime minister of New Zealand, served as the Director-General (DG) of the World Trade Organization (WTO) during the three most eventful years in its history. His term began in 1999, just before the notorious meeting in Seattle where violent protests and the WTO's own lack of preparation resulted in the collapse of plans to set up a new round of multilateral negotiations to liberalise world trade. However, before his term ended, Moore was able to steer the WTO through the Doha meeting at which the new round was successfully launched.

Moore's basic thesis is that trade liberalisation is an important form of openness, openness is usually good for growth, and growth is usually good for most of us, including the poor. Along the way, he gets in a lot of good hits on the NGOs and other opponents of the WTO who claim to be concerned about the poor, but often have no interest in open debate, nor any concern for the real facts about the effects of trade liberalisation.

Moore has first hand experience of interesting and important events and a nicely self-deprecating sense of humour. After getting the WTO job, he writes, 'I gave my last speech in Parliament and to the party caucus. My friends wanted the best for me, and my enemies wanted to see me go. For once, I was able to please everyone. At last, I enjoyed the total support of my party (p. 96)'. Unfortunately he is too ready to indulge his love of collecting facts and pouring out ideas on every subject under the sun, without bothering to check which are relevant to his thesis, or even which are consistent with it. The book also suffers from his readiness to quote academic gobbledegook, from carelessly constructed sentences and from the jargon of international organisations: 'stakeholders', 'Ministerials', 'resurging', 'impacting' and 'evolving' - as in 'we are now evolving answers'. Here are some examples of these defects:

(Robert Muldoon's) response to the oil crisis and every other problem was even more control and huge taxpayer-backed doomed think-big Sukarno/Soviettype projects to make New Zealand independent of world prices, such as a gas-togasoline plant (p. 2).

But there is a politically correct attitude within elements of the membership (of the WTO) that says, because when major powers need something they are automatically wrong, that it is a trick by the rich to oppress the poor (p. 113).

The report (of the Commission on Macroeconomics and Health) states that each life year is valued at around three times the person's annual earnings, 
reflecting the value of leisure time, market consumption, the pure longevity effect, and the pain and suffering associated with disease. A lost life at twenty is by some estimates taken to be equal to a hundred times or more annual earnings (p. 252).

By the mid-1990s the pension systems of the transitional economies were saddled with crippling high dependency rations (p. 257).

The book is divided into three parts. The first 90 pages argue at unnecessary length that globalism is mostly wonderful - and when it isn't, it's inevitable anyway. The second part, which describes his term as DG of the WTO is by far the most interesting. One of his best anecdotes tells how a negotiator at Doha told Moore that he had been converted to the proposed deal, but had unfortunately already promised his parliament not to support any new round. Moore suggested that they call it the 'Doha Development Agenda'. That became its official title and the problem was solved. In the final part, Moore gives his views on just about every topic imaginable: NGOs, corporate social responsibility, the environment, AIDS, population aging, immigration, the role of women, GM foods, eugenics and human genomes. Cambridge University Press's proof reader, if there was one, should be sacked.

Moore grossly overuses the quote-with-approval method of making points. Sometimes these quotes are a lengthy way of saying nothing very much:

Hans Küng correctly observes (p. 220):

At the latest since the Second World War, despite all too manifest resistance, a new post-modern paradigm of politics is now slowly and laboriously becoming established, which is no longer Eurocentric, but polycentric, and which in a post-colonial and post-imperialistic way aims at a truly united nations ... there is a middle way between real politics and ideal politics. This is the way of a politics in the spirit of an ethic of responsibility.

However, the quote below undermines the basic theme of the book (p. 227):

Nobel prize winner Joseph Stiglitz, past Chief Economist for the World Bank, ... writes: ' ... trade liberalisation accompanied by high interest rates is an almost certain recipe for job destruction and unemployment creation - at the expense of the poor. Financial market liberalisation unaccompanied by an appropriate regulatory structure is an almost certain recipe for economic instability - and may well lead to higher, not lower interest rates, making it harder for poor farmers to buy the seeds and fertilizer that can raise them above subsistence.

Coming after 226 pages of unqualified support for trade liberalisation, this is a stunning qualification, despite the italics. I think Stiglitz is wrong and the rest of Moore's book suggests that he does too, since it ignores the level of interest rates when making the case for trade liberalisation. For example, Moore reports that 'the elimination of all tariff and non-tariff barriers could result in gains for developing countries of the order of $\$ 182$ billion in the services sector, $\$ 162$ 
billion in manufacturing and $\$ 32$ billion in agriculture (p. 167)', but does not report the assumptions about the level of interest rates on which these estimated gains are based. ${ }^{1}$ Nor, incidentally, does Moore report whether these estimated gains are increases in trade, increases in GDP or measures of compensating or equivalent variation. They are suitably big, so it doesn't seem to matter how they were obtained, or what they really measure.

If Moore shares my belief that Stiglitz is wrong, he should have explained why, instead of merely quoting Stiglitz's views with apparent approval. In fact, however, financial regulation and interest rates are among the few topics in economics, history, political science and philosophy on which Moore does not offer an opinion. Alternatively, if Stiglitz is right, it is clearly important to know just how low interest rates must be if trade liberalization is not to destroy jobs and hurt the poor. Before concluding that the Doha round was going to help the poor, Moore should have checked to make sure that 'appropriate' financial regulatory structures were in place throughout the developing world. If they weren't, as seems likely, perhaps developing countries should have been raising their trade barriers.

Another issue that is closely related to Moore's area of expertise is the role of the most favoured nation (MFN) principle in the WTO. Moore defines this twice (pp. 50 and 104) and identifies it (p. 50) with the principle of 'do as you would be done by'. Actually, it corresponds to the principle 'do what you like to others, as long as you do the same thing to all of them'. Moore argues that:

The principle of non-discrimination ensures that the WTO treats all Members alike, be they rich or poor, big or small, strong or weak. Central among the rules that underpin the principle of non-discrimination is the 'most favoured nation' obligation (which prevents WTO Members from treating products from one WTO Member better than those from another) ... . Non-discrimination has been the key to the multilateral trading system's success (p. 104).

In fact, the WTO has become increasingly ready to accept deviations from the MFN principle, and rightly so in my view. One such deviation is the sanctioning of plurilateral agreements - that is, agreements among groups of WTO members that each will grant concessions, such as national treatment, to those that join the group, but not to other WTO members. Despite his praise for the MFN principle, Moore proposes a plurilateral agreement on tourism (pp. 165-66) that would violate the MFN principle.

Another exception to the MFN principle is tariff discrimination by developed countries in favour of developing countries. This is permitted under the generalized system of preferences (GSP). Moore does not discuss GSP explicitly, but praises the EU's 'Everything But Arms' (EBA) initiative (p. 125), which is a kind of super GSP scheme that grants duty free access to the EU to most products from the least developed countries, although it will not apply to bananas, sugar and rice until 2006-08. Moore gets its name wrong - he calls it 'Anything But Arms', does not explain what it is and does not point out that both EBA and GSP

1 Presumably these estimates come from a static model in which there is no interest rate. 
are inconsistent with MFN and flatly contradict the principle that 'all members should be treated alike, be they rich or poor ...'. The best thing in his discussion of EBA is the joke that the title should have referred to 'Farms', not 'Arms'.

The most controversial deviation from the MFN principle is the creation of discriminatory free trade areas (FTAs) and customs unions. Moore never analyses the pros and cons of these arrangements, although they are rapidly becoming very important. I think that a good case for allowing them can be based on the political advantages of reciprocity as a way of facilitating partial trade liberalisation, when better policies are not politically feasible. Although he doesn't discuss FTAs, Moore makes an excellent case for the need for reciprocity in trade negotiations (p. 135):

Often, countries cannot make unilateral moves politically; reciprocity enables them to liberalise in these cases. Reciprocity enables politicians to mobilise the pro-trade groups, who will visibly profit from new export markets, to counter the anti-trade protectionists groups who typically oppose trade liberalisation.

He points out that reciprocity is embodied in WTO negotiations to reduce trade barriers on an MFN basis. While this is true, it is embodied even more directly in agreements to set up FTAs and customs unions, which limit free riding on reciprocal agreements in a way that non-discriminatory trade liberalisation does not. It is possible for such arrangements to do more harm than good by diverting more trade than they create, but this does not mean that trade liberalisation among members of a discriminatory FTA is not often a practical way of making a modest improvement in situations in which unilateral liberalization would be politically infeasible, and waiting for agreement among all WTO members to reduce tariffs on an MFN basis would be a recipe for inaction.

The impression of Mike Moore that one is left with, after reading this book, is of an energetic and impatient fighter for freedom and openness, overflowing with ideas and determined not to let red tape, or anything else, stand in his way. These qualities probably made him an excellent choice for DG of the WTO. I hope that his next book is more reflective, more carefully written and better focused on the things he knows about at first hand. Thorough proof reading wouldn't hurt either.

George Fane is Professor of Economics in the Research School of Pacific and Asian Studies at The Australian National University. 


\title{
Republicanism
}

\author{
Mark McKenna and Wayne Hudson (eds), Australian Republicanism: A \\ Reader, Melbourne University Press, 2003
}

\section{Reviewed by John Uhr}

$\mathrm{F}$ or well over 200 years, republicanism has been debated in Australian society. This collection of key documents traces the persistent republican hopes and the equally persistent anti-republican fears. The book has all the recent highlights: the Australian Republican Movement (ARM) core statements, the Keating government advice and early promises, the 1998 Constitutional Convention debates and the 1999 referendum arguments. But more than this, the book publishes the political arguments over republicanism, opponents as well as advocates, since the early 1880 s.

Why did the recent experience fail to deliver constitutional change, and what is the future of republicanism in Australia? This book has the answer: based on the extensive documentation now published in this impressive new reader, the republic debate could also have a long future, including unresolved wrangling over competing models of an Australian republic. This sad prospect is not the primary intention of editors McKenna and Hudson, but it is one conclusion that is consistent with the historical record. One of the surprising strengths of this book is the depth of diversity it provides for those wanting to track the various strands of republicanism in the Australian experience of this venerable political belief.

Mark McKenna is an ANU political historian who has written the main cultural history of republicanism in Australia. Wayne Hudson is a political theorist at Griffith University who has published extensively on citizenship. Together they provide a useful running commentary on the documents they select. Be prepared for extensive coverage of the royals: typical of the national mood that has conditioned the republican option is this classic contribution from former Prime Minister Menzies in 1954: 'We love the Queen. We honour the Queen. We serve the Queen'. This very readable collection of documents, and commentary on the history of republicanism in Australia takes its cue from the quandary over the Queen and the British monarchy she represents.

The sad truth that emerges from this book is that republicanism in Australian has been preoccupied by the vices of the British monarchy, almost to the exclusion of any sustained investigation of the countervailing virtues of the post-monarchy nation: an alternative republican polity without the trappings of a constitutional monarchy. Australian republicanism spends more time making fun of the mindset of the Menzies monarchists than spelling out the detail of republican institutions, including, but not confined to, an Australian head of state. This reader shows just how enduring this reactionary strategy is, with the implication that time is on the 
side of the monarchists, even though the monarchy does not attract majority support.

The book begins, even on the cover, with a portrait of the current Queen. This is no criticism, because this image nicely captures the problem confronting Australian republicans: selecting alternative images to convey solutions to this highly personalised problem. In many ways that monarchists appreciate, the visible person of the current Queen papers over the deeper problem with the office she holds as Queen of Australia. Republicans call on Australians to imagine an Australian - 'one of us' - as our head of state. But the answer is not an Australian monarch, despite the fact that such a monarch would pass the 'one of us' test. Monarchy too must go: but should it go because it is foreign or because it is bad in principle? And if it is bad in principle, what precisely is the principle being used as the standard of judgment? As this welcome reader shows, the historical answers to these questions have varied enormously.

The editors do a major service by confronting readers with the hard truths about Australian republicanism. The main story is one of nationalism (folk pride) crowding out democracy (self-government). The cover portrait signals the major preoccupation of the readings selected for inclusion in this book, almost all of which deal with the case for or against the monarchy in Australia. At many times, these readings seem like lost pages out a companion reader on Australian nationalism, where national identity is defined by 'republicans' simply in terms of being non-British and by non-republicans in terms of some sort of imperial identity energised from England, as exemplified by Menzies. A very prominent theme of Australian republican sentiment is nationalism, occasionally revealing anxieties of xenophobia. At its best, republican nationalism substitutes an Australian scale of public honour for the traditional one inherited from Britain. For instance, The Bulletin of 1887 inveighs against 'that crowd of place hunters whose centre of gravity is England instead of Australia'(p. 84). But as this reader shows, this not-unattractive assertion of national pride has often become a plea for racially exclusive chauvinism, complete with sexist stories about male political mastery.

The main republican application of this nationalist sentiment has been the menu of minimalism: republicanism defined in terms of severance of the constitutional link to the British (and indeed to any other) monarchy. This version of republicanism is more radical than it sometimes appears: it is not simply a substitution of an Australian head of state for the British monarchy but a thoroughgoing rejection of monarchy as such. But is it also an embrace of political equality and a commitment to substantive social democracy over and above the formality of constitutional democracy? Or is it a 'meer breeches pocket question' with calculations of personal cost, as the Peoples Advocate wondered in 1849? (p. 35).

In a way, the answer is not yet in, because republicans have yet to test their mettle against anything more challenging than strains of minimalist monarchism. There are plenty of examples of this conservative position from the anti-Labor side of politics, but perhaps the most telling example in this collection comes from 
that most rascally anti-Labor rat, Billy Hughes, who has a starring role here for his outstanding contribution to the anti-republican camp. Near the centre of the book is Hughes' speech of welcome for the visit of the Prince of Wales in 1920, just a few years after Australian involvement in the First War. No mention on this occasion of an independent new nation 'blooded' in battle, but instead hearty sentiments about the proud place of the British Empire in the Australian outlook, including Australian acceptance of the principles of civil liberty associated with British government. This is in marked contrast to the related extracts from the Australian Worker, condemning the vices of British and any other form of imperialism. Hughes, on the other hand, had a new relish for imperialism. A little later in the same year we find Prime Minister Hughes leading the parliamentary censure of federal member Hugh Mahon for alleged 'treason' arising from his outspoken defence of Irish republicanism. Here the little digger does make the link between the Australian war dead and the non-republican ideals of empire for which they died (see, for example, p. 156).

Many Labor figures were just as cool towards republicanism. Hughes had outgrown the radicalism of his youth, but even the anti-monarchist Labor radicals of his day, like Maurice Blackburn, were no less impatient with republican ideals that were 'side-tracking the working class movement just as much as the advocate of monarchy' (pp. 150-1). To cite Blackburn's wonderful example of Hawkeeyed realism: 'The thing to do is to make the best of the existing form' (p. 151). This makes even Keating's republicanism look radical!

This book shows that the republican debate has from the beginning included a debate over ideas as well as institutions. But many of the leading ideas are slogans. For instance, the first reading is a newspaper report from 1806 about a convict charged with sedition for wearing a shirt with the name of English republican Tom Paine identifiable on the back. Clearly Paine pained the authorities, and this early republican suffered for his early adventure in identity politics. But later republicans had even zanier ideas. Consider what is probably Australia's original political manifesto proclaiming republicanism: the manifesto of the 1891 Australasian Republican Association (ARA), which should be betterknown, does not even mention the monarchy. Could this be the missing example of maximalist republicanism? Enthusiasts should be wary, because the ARA was as much a racial movement as a radical movement. The manifesto calls for universal suffrage, triennial parliaments and the referendum (all good things), and opposes imperial titles (the closest it gets to mentioning monarchy). But its real passion was to preserve 'Australia for the white man' (p. 108), which rather undercuts its appeal in this fascinating model of the so-called 'Democratic Commonwealth' that the ARA contributed to the federation debates.

This collection contains many of the best anti-republican defences of the established Australian order. While journals like The Bulletin might rail at the 'dust covered customs' of England of no real relevance to Australia (p. 93), more mainstream journals like The Age newspaper had already sold their readers on the good sense of being 'loyal to the British crown but not to British absolutism': a classic expression of Australian self-government (p. 63). The conservative 
version of this support for responsible parliamentary government warned Australians off republicanism because it was American, and therefore un-British. Thus the scallywag Wentworth called for a 'British not a yankee constitution' (p. 47), a view put with greater balance by the centrist Henry Parkes (pp. 38-9). What both public men feared was republican envy of the US, expressed in public sentiments along lines that celebrated 'that democratic habit of thinking which is the great and distinguishing characteristic of American society’ (p. 56).

In the nineteenth century, the deepest forms of republicanism were American in sentiment. But in the twentieth century, some of the deepest have been Indigenous in sentiment, invoking a spirit of reconciliation between white and black Australia. Few examples of this most recent spirit are included here, with the notable exception of a speech by Gatjil Djerrkura (pp. 232-4). Also missing are those voices, other than Paddy O’Brien at the 1998 Constitutional Convention, of populist republicanism favouring direct election of the president. These two omissions weaken the representation of contemporary left-wing and right-wing republicanism.

But the real strength of the collection is the fresh picture it paints of what might be called the robust republicanism of the advocates of democracy in Australia. Advocates like John Dunmore Lang approached republicanism as an exercise in political self-government, seizing on the prospect of Victorian selfgovernment to draw up a declaration of independence anticipating an eventual federation of like self-governing colonies committed to the core value of popular sovereignty. In such voices, Australian republicanism recovers its democratic credentials. But, as they say in the classics, there is more: Lang was one of those who appreciated that Victorian Britain was already in substance a republic, even if a disguised one, and that the Australian colonies were following suit. Even Parkes, who feared the 'wild ravings' of republicans, conceded that Britain was a disguised republic (and that the US was really a monarchy) and that Australia was safely on track to achieve closet republicanism (p. 126). This sentiment was aired during the 1890s federation debates, here extracted in contributions from that unlikely republican hero, the inaugural President of the Senate, Richard Baker, who acknowledged that Australia was 'practically a republic' (p. 137).

The contemporary who comes closest to this version of republicanism realism is Donald Horne, whose 1964 classic The Lucky Country made the same admission that Australia was, for all practical purposes, a republic (p. 181). Horne also made the original case for popular election of an Australian head of state, before discounting its likely effect: 'One might think that such a dignitary (an appointed President) would have to be elected by the Australian people but the Australian political leaders might prefer to sneak him through a back door' (p. 182). Perhaps Australians can take quiet pride in the fact that they live in a nation that is lucky enough to 'do' republicanism without 'being' a republic. Nothing, it seems, is all that new in the republic debate.

John Uhr is Senior Fellow, Political Science Program, Research School of Social Sciences, The Australian National University. 


\section{NON-AGENDA}

With the view of causing an increase to take place in the mass of national wealth, or with a view to increase of the means either of subsistence or enjoyment, without some special reason, the general rule is, that nothing ought to be done or attempted by government. The motto, or watchword of government, on these occasions, ought to be - Be quiet...Whatever measures, therefore, cannot be justified as exceptions to that rule, may be considered as non-agenda on the part of government.

— Jeremy Bentham (c.1801)

\section{Fund Managers and Superannuation}

\section{Stephen Grenville}

$\mathrm{T}$ This paper gives an outsider's reaction to some aspects of retirement income in the current system. There are big issues here, both for superannuants (are they getting value-for-money from their managers?) and for the economy (is Australia achieving the right level of saving and getting its investment into the best projects?). In the face of the complexity of the issues, it may seem bold for an outsider to venture a view: but there are important unresolved issues and questions. This paper will not resolve them, but might serve to put some of them more centrally on the agenda for discussion.

The starting point is with fees - how big are they, and what you get for your money. One thing you get is funds management, but we pose the question here whether funds managers in general can provide advice which will beat the market - that is, do better than a mechanically-indexed fund. Some evaluation of retirement incomes is attempted - first at a general level, then focussed on whether the superannuation industry is meeting the needs of the superannuant, and finally whether the needs of the general economy are being well served.

\section{Fees: What Do We Get For Our Money?}

Before we can make any sensible assessment of fees, we need to establish what service is being provided in return. Functional distinctions made here will be somewhat arbitrary, but it may be useful to divide the overall role into three components - distribution/advice, administration, and fund management proper.

At the retail level, three sets of rules lend a special complexity to the distribution/advice component. Much of retirement saving is done in the form of

Stephen Grenville is Adjunct Professor at the Asian Pacific School of Economics and Government, The Australian National University, and former Deputy Governor of the Reserve Bank. 
the compulsory Superannuation Guarantee Levy - the compulsory nine per cent deduction from incomes, and there is a set of rules governing this, as well as general rules covering superannuation. Secondly, there are special taxation rules associated with these funds, as they go into the financial vehicle, as they earn income and capital gains there, and as they come out again. And these rules operate alongside the government pension framework, with complex eligibility rules for asset tests and part-pensions. These three sets of rules and entitlements combine to provide a degree of complexity that few savers want to tackle without specialised advice.

The second function is administration: once the money is allocated to superannuation saving, its disposition among investment vehicles needs to be tracked, income and capital gains recorded, taxes paid, distributions made and all this reported not only to the investor, but in a form which also satisfies the requirements of tax, superannuation and pension rules. This function is like shelling peas - you have to be careful and there are a lot of little things involved, but it ought to be straightforward enough to be largely a computer exercise.

The third function is funds management proper - finding the highest return given the risk appetite and liquidity requirements of the investor. The fee charged for fund management (either within the same institution or paid to a specialised manager) depends on the type of investment and whether the fund is actively managed or passive. This ranges from a little over 0.1 per cent for simple passive funds, to around 0.6-0.7 per cent for active management.

\section{Fees: How Big?}

It is not easy to get a simple handle on fees. The topic may be intrinsically difficult, but the industry groups are quick to criticise those who attempt to analyse returns (see, for example, criticism by the Association of Superannuation Funds of Australia (2003) of the Australian Prudential Regulation Authority's (APRA, 2003) Working Paper on this subject, without offering much of an alternative: they are still arguing about an agreed disclosure model (see, Sydney Morning Herald 'Money Manager', May14, 2003).

Perhaps the most straight-forward of the studies is from the Reserve Bank of Australia (2003). Unable to get a simple representative measure of fees, the RBA study focuses on the expense ratios of super funds, which are a little over one per cent of assets for wholesale funds, and around two per cent for retail. At retail level, there is an additional commission paid to agents for helping the investor. A small sample of brochures suggest these agent's fees can be around 4 per cent as a once-off charge or an equivalent figure spread out via 'trailing commissions', which the RBA suggests might amount to around 0.4 per cent per year.

Other studies (for example, Clare (2001), Rice and McEwin (2002), and Bateman and Mitchell (2001)) quote significantly smaller numbers, but these seems to be partial figures, which may be relevant to the working employee, but not to the retiree, accessing retail superannuation products. Using data from its annual data-base and a (low) estimate of external investment expenses, APRA 
(2003) found the average expense ratio to be 1.28 per cent, with this average made up of a range from 1.25 per cent for the corporate sector, to 1.56 per cent for the retail sector.

As an illustration of the difficulty of getting a clear handle on the size of fees, the Sydney Morning Herald's regular writer on this topic quoted fees of 1.27 per cent and, a few paragraphs later, of 2-3 per cent, without commenting on (let alone reconciling) the 100 per cent disparity (Sydney Morning Herald, October 11-12, 2003).

If we accept the RBA estimate, such fees more or less negate the taxation advantages of super for many retirees, even those on the highest marginal tax rate. A simple example illustrates the point. Assume a good return of 10 per cent. If this income is received outside the superannuation framework, the tax-take is close to five dollars out of the income for every $\$ 100$ invested, compared with a tax-take of around \$3 within the superannuation framework. But the fund manager then takes another \$2.00, without counting the entry fee. And if the return was five per cent rather than ten, the fee would take up well over half of the after-tax income.

\section{Funds Management}

In practice much of the broad asset allocation advice tends to be driven by pension eligibility and taxation consideration, and by the general principle of asset diversification. This is sensible enough, but it does bring to mind the story attributed to James Tobin, who won the Nobel prize for (among other things) his contribution to portfolio theory. When asked what this was about, he is said to have replied: 'It means that you shouldn't put all your eggs in the one basket'. Investors might hope for more precise advice.

Tobin's work, plus the related areas of Modern Portfolio Theory (MPT) and the Capital Assets Management Model (CAPM), do in fact offer the promise of more precise advice, but how relevant is this?

The problem here is that all this rests on the idea that 'risk' can be encompassed in the variance of returns, and in particular in a 'beta' (a measure of variance) which is well defined and stable. At least at an intuitive level, it seems far too simple an idea to capture the complex and diverse nature of risk, especially as so much risk is once-off, and more in the nature of uncertainty rather than risk (that is, it can't be captured by a reasonably well-defined probability distribution based on historical data.). At an intuitive level, there seem to be other problems as well. If the only issue is short term variability (as captured by the beta), the rational investor should choose a variable 10 per cent return over a steady eight per cent, because over any time horizon other than the very short term, the investor will be left with more money. The risk in an equity at the peak of a bull run is not captured in any meaningful way by the beta. Beta-based analysis would also suggest little change in portfolio composition over the course of the cycle (whereas the best portfolio managers will provide their greatest value-added by good calls of major asset re-allocation at turning points in the cycle). As well, this 
analysis would suggest a greater variety of assets in the portfolio (especially a greater proportion of foreign assets) than happens in practice. So there must be more to 'risk' than this, and the beta concept does not seem to be the essence of the investment decision.

There is another, related, argument coming out of this same literature - the idea of 'efficient markets' (also associated with the idea of the 'random walk'). The argument here is that all information has already been incorporated fully into asset prices. This would still leave the possibility that investors might be able to get a higher return by taking on more risk, but if this risk can't be identified more effectively than through the beta (and recent experience shown no correlation between risk, as measured by beta, and return), then the professional investment advisor has little to offer in the way of specific value added.

Here we find a curious ambivalence in fund managers' thinking. Quizzing fund managers about their faith in 'the magic of the market' we find they are, by and large, believers in the principle that markets work well: they adhere to the 'efficient markets' view of the world. But if this is so, the next question must be where they think their own value-added comes from. Either the fund manager must have inside information, not available to the rest of the market (which is by and large illegal), or there must be a combination of two circumstances - the market is not the same perfect efficient market of textbooks and finance theory, and, in addition, the fund manager understands the working of this non-perfect market in a way which will enable the funds to be deployed ahead of market movements.

The real world does seem to behave differently from the text-book 'efficient market'. Even casual observers of the markets can see behaviour which, if the text-book model were right, would be impossible or at least very unusual. For example, markets seem to over-react to 'news' - new information, and 'herd behaviour' seems common - indeed, the norm. Another regularity is reversion to mean: after share prices have been pushed up by a bout of euphoria, there comes a point (perhaps triggered by a minor event or piece of news) when the euphoria evaporates and the price falls, probably to lower than its long-term average. If we combine these two offsetting tendencies, we might observe prices moving in the same direction for some time (that is, transgressing the efficient markets rule by being auto-correlated), but for this to be reversed and for the 'fundamentals' to reassert themselves (perhaps with an overshoot in the opposite direction). Financial prices - exchange rates, equity prices, bond prices, physical asset prices - move in cycles of bear and bull markets, and such phases are easy enough to identify in history - the cyclical movement of share prices does not look like a random walk. If a fund manager could predict even some of the dynamics of these cyclical or structural swings, then they could beat the market - because the market is not 'perfect'.

This is, to say the least, a very different world from MPT and CAPM. It is closer to Keynes (1936:155-6) description of the stock market, which he described as: 
so to speak, a game of Snap, of Old Maid, of Musical Chairs - a pastime in which he is victor who says SNAP neither too soon nor too late, who passes the Old Maid to his neighbour before the game is over, who secures a chair for himself when the music stops.

Serious fund managers might argue that there is more skill to it than this, but the metaphor does highlight the basic problem. Even if there are medium term cycles in financial markets, fund managers will often get their timing wrong: 'noone rings a bell when markets change'. If they were perfectly free in their portfolio management role, they might stand a chance of getting the timing more or less right, getting into the market somewhere near the bottom and selling somewhere near the top. But they don't have this freedom, because they are generally judged against a time horizon, which is far shorter than the market cycle, and even minor errors in timing will be evaluated adversely, with investors withdrawing their funds before a position has time to prove itself.

If they are evaluated by usual measures such as 'how did your portfolio go this quarter?', they will experience times when what turns out to be a good call is not validated quickly enough to save their bacon in the fiercely short-term evaluation of investors. This is why the best of the active funds managers tend to gravitate to boutique operations where the larger investors understand the issue and are more patient. BT's famously prescient call on the 1987 stock market fall almost failed because they made it six months too early. Or, for an even more dramatic example of premature timing, look at Alan Greenspan's (1996) call of 'irrational exuberance', made in 1996, five years too early, when the Dow was less than 7000. Whatever the counter-examples, there are strong incentives for funds managers to stick with the pack (even when they are supposed to be active managers). Better to be wrong along with most others, as Keynes (1936:158) said: 'Worldly wisdom teaches that it is better for reputation to fail conventionally than to succeed unconventionally'. Fund managers want to beat their competitors, but each knows that job security lies in staying close to the pack.

Can a truly active funds manager survive for this long, judged under shortterm performance criteria? Can the investor distinguish between a funds manager who is profitably riding the long cycle, and one who has lost the plot? All the rules of thumb ('cut your losses; sell losers') are working against it.

It ought to be possible to test this definitively through the most practical and relevant measure of all: who performed best? The issue is usually tested on the basis whether active managers can beat passive index-managers. This is, in fact, a narrower question than the one we have been exploring, which was more about the possibility of calling turning points that would signal radical re-allocation of the broad asset categories. If there are regular cycles, it is not enough to judge fund managers by their ability to beat the market within one narrow asset class (such as equities), but we might reasonably ask them to re-jig the asset mix of our portfolios in order to ride out (and benefit from) the cycle. So they should have put us in equities during the early days of the 'tech boom' and got out as the 
bubble was bursting. No doubt some did. But many fund managers are confined largely to staying within a general asset category, and so most investors were left to weather the cycle, with the cold comfort that came from comparisons of their own portfolio with the dismal average of the market.

We know of no careful study of this wider issue of asset allocation, so here we will report the results of the narrower issue: who beat the index? In the USA the answer is reasonably well accepted: taking into account fees, only one third of active managers can beat the index (see Malkeil, 1999). They don't beat the index by much, and past performance on beating the index is no guide to whether particular fund managers will beat it in the future. This should not come as any great surprise to anyone who accepts the broad conclusion of the Efficient Markets Theory: As Bill Sharpe (another Nobel prize-winner for work on portfolio theory) has pointed out, if the market is made up of indexers and active managers, the active managers must, on average, get the index return and, after fees, the investor in an active funds (again on average) gets less (Sharpe, 1991).

What is the Australian experience? An informal survey of the literature might conclude that, taken over the last couple of decades, active equity managers have been able to beat the index by an amount which would more or less cover their fees (see, for example, Dolan, Hodgens, and Wells, 2001; Dolan, Hodgens and Wells, 2003; Drew, Stanford and Veeraraghavan, 2002; Fitzherbert, 2000; Frino and Gallagher, 2000; Gallagher, 2000; Graham, 2002; and Hayes, 2001) but the more recent experience is tending towards the US result, namely that on average the active managers don't outperform the index (see, for example, Drew and Stanford, 2003).

In the market-driven assertions made by funds managers, it would be easy to reach misleading answers. A number of technical issues need to be covered. Are some funds getting higher returns by taking more risks? Do they beat the index because they have special access to IPOs? Are the data polluted by 'survivor bias' - the fact that the least successful managers have dropped out of the sample? Is the sample comprehensive, or has it allowed managers to be judged on their more successful funds? All these matters could be debated (and should be); but for our purpose here it might be enough to note that, whatever the performance of the managers in the days when the market was less well-informed than it is now, the strong tendency will be for the outcome to move in the direction of the efficient markets paradigm, in which it will be hard for managers, on average, to beat the index.

One more aspect of funds management might warrant a comment: the vogue for offering actively-managed funds in terms of 'style' designations; that is, is the fund 'growth' oriented or 'secure'. Again there seem unresolved issues. Perhaps one of the most vexed issues is the notion that 'growth' as such should add value to a share. The price of an equity is closely related to the discounted present value of the expected income stream, so of course it is true that if there is going to be a larger income stream, the equity should be worth more (other things being equal). But if the higher income simply comes about because the firm buys another going firm, or buys more equipment to increase its capacity, then its dividend will 
increase but there will be the funding costs of the expanded capacity that have to be met. Thus we need to know where the growth is coming from, and at what funding cost. Is it totally organic, falling like manna from heaven without further investment or effort (in which case this prospect will certainly add something to the share price), or is it simply expanding capacity through acquisition, with no particular reason to think that this will make the existing equity more valuable. For management, of course, growth brings greater prestige and benefits, so their keenness is understandable. But it is surprising that 'growth' is seen as such a desirable thing for shareholders as those who wants to enlarge their portfolio can do so by buying more shares. If a firm already has a profitable operation, there is no advantage to shareholders in diluting this by purchasing assets with a lesser yield.

\section{A Tentative Evaluation}

In evaluating whether the superannuant is getting value-for-money from the fees, we might return to the three-way distinction among the services provided. First, there is the distribution/advice function. We noted above that, because of the opportunities to exploit the complex regulations of taxation, superannuation and pension entitlements, it may well be that the superannuant receives a good return on the cost of advice, from his personal standpoint. What should be noted, however, is that this is a deadweight cost on the system - not only is this advice adding nothing to the value of investments, but every extra dollar shifted to the superannuant is a dollar less for other taxpayers.

What of the administration aspect of the task? Seen in terms of a straightforward book-keeping function, it is hard to see why this should be expensive for the average superannuant's account, in a world of cheap computing power. As for the funds management proper, we have argued above that it seems quite doubtful that, looking ahead, the average superannuant would get any net benefit from active funds management, and would do better to adopt a diversified asset allocation strategy, with a significant weight of indexed equities, for which routine task the funds management fee should be minimal.

If this view is correct, there would seem to be room for lower fees on all three components. If the value of the distribution/advice is largely in how to exploit the rules, the need is to simplify the rules so that people easily get what they are entitled to, and no-one (however much they squeeze the system) gets more. This might seem idealistic, but it is the right starting point, and should be an important policy objective. If administration is about computer-power, there may be set-up costs and economies of scale, but this should not be taking the large chunk of fees that it is at present. For the funds management component, the issue is whether the industry is promising something that over-all, it cannot provide, namely above-average returns for everyone.

How is the system likely to evolve (or how can it be encouraged to evolve) to give better value-for-money to superannuants? As the industry matures, competition might produce a better product. But we can observe that it was not 
enough to have competition between banks to get bank home mortgage lending fees down: it was only with the arrival of an outsider with no existing profitable business (Aussie Homeloans) that the exorbitant margins for the safest lending in the books (home mortgages) came down. What will be the equivalent to Aussie? The problem here is that when you give your superannuation money to someone to manage, this is usually a very long contract which, for most people, will be a large part of their life-time wealth (especially if we exclude the family home). This is not an environment where competition will be as vigorous - or the buyers as experienced - as, say, the market for groceries, where we all know a fair amount through constant exposure to transactions. The investor may not be able to judge the institution and its performance easily or quickly - a recent ASIC (2003) survey pointed to widespread investor ignorance - it is not so easy as telling whether the produce is fresh and the counter is clean.

The role of the investment advisor is critical in this, but the position of the agents seems quite ambiguous. Just when the investor needs unbiased advice to steer through the thicket of tax, pension and superannuation regulation and (on top of that) find a funds manager who can get a good return, the investment advisors have no incentive at all to make the process simple or transparent: the more complex, the more the agent can charge. Moreover, the advisor is often on both sides of the transaction. The agents are usually paid by the investor, and certainly act as if it is the investor's interests that they are pursuing, but they often have special relationships and 'trailing commissions' from the supplier of the investment product. There is rarely a simple principal/agent relationship with the investor, with the agent unambiguously pursuing single-mindedly the interest of the investor. Would we trust a doctor who asked us to pay no fee for service, but received an on-going commission from a drug-supplier if we could be persuaded to undertake a long-term commitment to expensive drug treatment? (This example was suggested by the Sydney Morning Herald, 2 August 2003).

Will the investor be able to rely on the protection of the regulator to ensure that the investment advisor and the fund manager do a good job? ASIC's recent study suggests that most of the investment advisors are doing poorly, and this was evaluated against a quite mechanical and undemanding standard. There is little doubt that, after the experience of HIH, APRA will be readier to exercise its powers. But how far can it realistically go, given the number of super funds? The regulator will always be 'a bulldog chasing a greyhound'. How far should it go, given that there has to be a high degree of consumer choice, with the 'buyer beware' that goes with this? And in any case we can't have the government taking responsibility to guarantee any particular outcome for retirees, beyond the already-huge commitment of the basic pension. So we will need to reconcile two disparate forces - the need for vigorous competition to get fund management fees down to levels which are commensurate with the true value added, and the need to avoid fund management disasters which leave people (that is, voters) with big losses in their compulsory saving.

If competition has not so far fixed these problems, what might be the way forward? Perhaps the best hope here is that the popularity of the fast-growing 
'wrap-fund' industry, which offers the service of administering the funds in a fairly 'unbundled' form. This provides the potential for market competition to turn the administrative function into a commoditised product, separated from the arcane world of fund management. This has not happened so far, with the wrap funds essentially charging much the same fees as the conventional superannuation funds. But 'unbundling' is often the precursor to the competitive reduction of fees, so there must be some hope for change here. If the three functions were unbundled, then the users would have a better view of whether they were getting value for money, and whether cheaper alternatives might be available.

Once unbundled, the elements might be more keenly priced. For the distribution/advice stage, the hope is that this might be provided by people who charged by the hour, as lawyers and doctors normally do. This would fit better with the idea that the superannuant needs advice at one critical stage - the shift to retirement — but not much at other times. The other element here, over time, must be a greater simplicity in the tax/pension/superannuation rules so that the opportunity for providing valuable entitlement advice is reduced: the rules should be such that people can judge for themselves what they are entitled to, and there are minimal opportunities to 'push the system' for personal advantage.

What about the pure funds management task? Will it become more apparent over time that funds managers cannot, in general, offer to the bulk of superannuants an above-average return, any more than we can all be aboveaverage in intelligence or beauty? In an unbundled world, cut-price indexers may help to make this unpalatable truth better-known. And within this generality, there are still opportunities for some patient people to do well with active management.

The hope is that the current interest in fees might lead one of the big players to break ranks and come clean on what they can do, offering two broad product characteristics:

- Cheap indexing, with minimal administrative fees, based on low distribution costs

- More complex strategies where the investor is paying for some demonstrated ability to understand the dynamics of the cyclical and structural movements in financial markets, and identify 'underlying value', with the investor understanding that these strategies pay off over the long run, and may be 'out of the money' for uncomfortably long periods

Such an institution would, in its tone and publicity, be very different from the current approaches. It would be more like Warren Buffett - modest and realistic, emphasising analysis of value rather than black box wizardry. What should it do about the cycle - try to exploit it with changes in portfolio composition? Unless it could get its customers to truly focus on the medium term, it will face a lot of criticism during the bear market (note that Buffett's Berkshire Hathaway reached its five year low at precisely the point where the Dow was topping in 2000 - and Berkshire has doubled since then). 
Of course there are opportunities for 'do it yourself' superannuation, which by-passes fees. The problem is not just that the regulations seriously limit the flexibility to manage the funds (for example, no gearing), but the complexity of the rules. Assistant Treasurer Helen Coonan is quoted (in the Australian Financial Review, 24 May 2003) as saying:

If you are going to do it, you have to comply. What I think is very important is that people know there are some great complexities in trying to do it yourself... and it's very easy to run foul of rules and regulations.

Hardly a strong encouragement for responding to excessive fees by selfmanagement. That said, superannuation policy-makers might follow the example of the instruction-booklets for electronic gear - there is the one-page introduction that covers the requirements of most of us, and then there is the 300 page esoteric guides for those who are attracted by complexity and want to get the most out of the system.

\section{Does the Present System Suit Superannuants?}

Fees are not the only issue for superannuants. For much of the investors' time horizon, it makes sense for them to put their retirement funds with a manager who uses theory and experience to get the best risk/return trade-off they can find. But at some stage the investment strategy needs to be re-examined to see if it suits the specific and idiosyncratic needs of the superannuant in the retirement phase, running down the assets. Are the sorts of risks faced by retirees the same as the risks the fund managers routinely address?

The first issue is composition of the portfolio. A truly risk averse retiree/investor might ask their manager to create a portfolio which mimics their expenditure basket. If a retiree envisages spending their remaining years living in the south of France with their feet in a bucket of champagne, then the low-risk portfolio would have a large component of French assets (and some champagne futures), as the main risk faced by this investor is that asset prices or the exchange rate will move to thwart their desired retirement. For more common mortals, the same logic might suggest a large share of accommodation in the portfolio, to match what may be the largest component of retirement expenditure (or investment in a nursing home!)

Most retirees, by accident rather than design (and without the advice of their advisers) do, in fact, go into retirement with a heavy weight of residential assets. That seems appropriate, and the missing element is the easy ability to run this down over time to maintain expenditure. The norm is that this is not run down, but passes to the next generation. This might give everyone a good feeling, but for a society struggling with the huge task of providing for retirement, this is a source of retirement funding which is not properly tapped. 
Perhaps the main risk for the retiree is that they 'live too long' - that they run down too much of the principal component of their assets. This is one of the curious aspects of the present industry: that this legitimate concern, which lends itself ideally to spreading of this risk through insurance (with the risk handled on the basis of the reliable demographic tables) — is so poorly catered for. So-called annuities generally provide income and return of principal over a fixed period of time, whereas what a risk-averse superannuant needs is a product that will insure them against the danger of a longer-than-expected life. Of course such annuities are available, but they offer such unattractive returns that few use them. A Table in the Australian Financial Review of May 312003 seems to say that the yield on life-time annuities ranges from negative to one per cent, while the yield on a fixed-term annuity is 3.38-4.25 per cent.

\section{Implications for the Performance of the Economy}

So far our view-point has been that of the superannuant. There are counterpart question that policy-makers should address: do these charges by the superannuation industry represent good value for the community? Benefits to the individual from exploiting superannuation, taxation or pension rules are at best a zero-sum game, so associated costs are a dead-weight loss to the system.

If fund managers succeed in identifying the highest-return investments (riskadjusted, of course) and steering funds in this direction, then there will be benefits to the economy as a whole through higher productivity and faster growth. But if many of the investment decisions are driven by tax and pension-eligibility, what does that say about resource allocation? What does the short-term focus of performance-driven funds managers do for investment optimisation? Index managers or quasi index managers (that is just about all of them) offer undifferentiated investment support to all companies in the index, without fear or favour and without regard to the company's governance or prospects. Not only are they passive between companies, but they are also passive over the course of the cycle: they will be supporting the bull market as it reaches its cliff-hanging peak, and will be making little attempt to 'buy cheap and sell dear' over the course of the economic cycle. Of course there will still be some active managers who will be searching out the best investment opportunities. We have suggested above that some superannuation investments (belonging to the 'patient' investors) will be under the control of that relatively-small group of managers who have some ability to beat the market fairly consistently over time. As economists, we believe that most of the action happens on the margin. And of course good resource allocation comes not only from the ability to pick the right projects, but from allowing Schumpeter's 'cold winds of creative destruction' to sort out bad projects swiftly (Schumpeter (1934)). The tech boom in the US might illustrate this money was thrown at projects without much discrimination, but eventually the market sorted it out. For investors, this may be cold comfort. 


\section{Conclusion}

Since compulsory superannuation first came on the scene in the 1980s, the nature of the policy debate seems to have changed. It was about the 'big issues' - how to provide retirement incomes in a sensible way, how to get the macro saving decisions right. To a large extent the public discussion has been taken over by the various vested interest groups (mainly the superannuation industry). The experts have been largely hired to argue the case of one or other of these interests. The dispassionate policy makers need to take over the debate again, and, as a first step, appraise where we are in the task of providing retirements income which eases the burden on the pension system, doesn't distort the tax system too much, gives superannuants a realistic appraisal of their retirement prospects, and makes a contribution to the efficient running of the economy — getting the right amount of saving, and steering investment into the highest-return projects. This amateur contribution hasn't much to offer on these weighty topics, but it suggests that we are still a long way from an ideal system.

\section{References}

Association of Superannuation Funds of Australia (2003), 'Recent Developments in Superannuation Fund Investment Returns’, available at www.superannuation.asn.au.

Bateman, H., and O. Mitchell (2001), 'New Evidence on Pension Plan Design and Administrative Expenses', mimeo.

Clare, R (2001), 'Are Administrative and Investment Costs in the Australian Superannuation Industry Too High?’, ASFA Reasearch Paper, November.

Coleman, A., N. Esho, and M. Wong (2003), 'The Investment Performance of Australian Superannuation Funds', APRA Working Paper 2003-1.

Dolan, P., P. Hodgens, and G. Wells, (2001), 'Rating the Performance of Active Equity Fund Managers', JASSA (Journal of the Securities Institute), Issue 4(Summer):1-8.

Dolan, P. P. Hodgens, and G. Wells, (2003) 'The Performance of Active Equity Fund Managers’ JASSA (Journal of the Securities Institute), Issue 1(Autumn):6-8.

Drew, M., J. Stanford, and M. Veeraraghavan (2002), 'Efficiency with Costly Information: A Study of Australian Wholesale Superannuation Performance' Economic Analysis and Policy 32(1):35-47.

Drew, M. and J. Stanford (2003), 'Returns from Investing in Australian Equity Superannuation Funds, 1991 to 1999’, Services Industry Journal 23(3):74-84.

Fitzherbert, R. (2000), 'Inefficient Markets and Irrational Investors', JASSA (Journal of the Securities Institute), Issue 1(Autumn):24-27.

Frino, A. and D. Gallagher (2000), 'The Problems of Being Passive', JASSA (Journal of the Securities Institute), Issue 2(Winter):28-32. 
Gallagher, D. (2000), Do Active Funds Deliver?', JASSA (Journal of the Securities Institute), Issue 1(Autumn):2-5.

Graham, P. (2002), 'Do Active Managers Really Outperform', JASSA (Journal of the Securities Institute), Issue 4(Summer):5-10.

Greenspan, A. (1996), 'The Challenge of Central Banks in a Democratic Society’, Speech to the American Enterprise Institute, December 5.

Hayes, R. (2001), 'In Praise of Inefficiency', JASSA (Journal of the Securities Institute) Issue 2(Winter):24-25.

IFSA (Investment and Financial Services Association) (2002) Report on Superannuation Fees and Competition, April.

Keynes, J. (1936), The General Theory of Employment, Interest and Money, Harcourt Brace, New York.

Malkeil, B. (1999), A Random Walk Down Wall Street, W. W. Norton, New York.

Reserve Bank of Australia (2003), ‘Australian Funds Management: Market Structure and Fees', RBA Bulletin, February.

Rice, I. and M. McEwin (2002), 'Superannuation Fees and Competition', Report prepared by Phillips Fox Actuaries for the Investment and Financial Services Association.

Schumpeter, J. (1934), The Theory of Economic Development, Harvard University Press, Boston.

Sharpe, W. (1991), 'The Arithmetic of Active Management', Financial Analysts Journal 47(1):23-26.

This paper was given to the Canberra Branch of the Economics Society in October 2003. The author acknowledges with thanks the insightful discussion with Greg Maughan, and the helpful comments of the referees. 